\title{
Lacunar stroke : a prospective clinical and radiological study
}

Citation for published version (APA):

Boiten, J. (1991). Lacunar stroke : a prospective clinical and radiological study. [Doctoral Thesis, Maastricht University]. Rijksuniversiteit Limburg. https://doi.org/10.26481/dis.19910628jb

Document status and date:

Published: 01/01/1991

DOI:

10.26481/dis.19910628jb

Document Version:

Publisher's PDF, also known as Version of record

\section{Please check the document version of this publication:}

- A submitted manuscript is the version of the article upon submission and before peer-review. There can be important differences between the submitted version and the official published version of record.

People interested in the research are advised to contact the author for the final version of the publication, or visit the DOI to the publisher's website.

- The final author version and the galley proof are versions of the publication after peer review.

- The final published version features the final layout of the paper including the volume, issue and page numbers.

Link to publication

\footnotetext{
General rights rights.

- You may freely distribute the URL identifying the publication in the public portal. please follow below link for the End User Agreement:

www.umlib.nl/taverne-license

Take down policy

If you believe that this document breaches copyright please contact us at:

repository@maastrichtuniversity.nl

providing details and we will investigate your claim.
}

Copyright and moral rights for the publications made accessible in the public portal are retained by the authors and/or other copyright owners and it is a condition of accessing publications that users recognise and abide by the legal requirements associated with these

- Users may download and print one copy of any publication from the public portal for the purpose of private study or research.

- You may not further distribute the material or use it for any profit-making activity or commercial gain

If the publication is distributed under the terms of Article $25 \mathrm{fa}$ of the Dutch Copyright Act, indicated by the "Taverne" license above, 


\section{Lacunar stroke}

a prospective clinical and radiological study 



\section{Lacunar stroke}

a prospective clinical and radiological study

\section{Proefschrift}

ter verkrijging van de graad van doctor aan de Rijksuniversiteit Limburg te Maastricht, op gezag van de Rector Magnificus, Prof. Mr. M.J. Cohen, volgens het besluit van het College van Dekanen, in het openbaar te verdedigen op vrijdag, 28 juni 1991 om 14.00 uur

door

\section{Jelis Boiten}

geboren te Hollandia (Ned. Nieuw Guinea) in 1957 
Promotor

Co-promotor

Beoordelingscommissie
Prof. Dr. R.S. Reneman

Dr. J. Lodder

Prof. Dr. J. Drukker (voorzitter)

Prof. Dr. J. van Gijn (Rijksuniversiteit Utrecht)

Prof. Dr. B.K. Janevski

Prof. Dr. E.B. Ringelstein (RWTH Aken)

Prof. Dr. F. Spaans

This study was performed at the Department of Neurology, University Hospital Maastricht, The Netherlands

CIP-DATA KONINKLIKE BIBTIOTHEEK, DEN HAAG

Boditen, Jells

Lacunar stroke: a prospective clinical and radiological

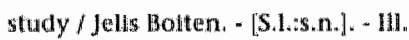

Thesis Matistricht. With ref. - With summary in Dutch.

ISBN $90-9004185-0$

Subject headingsi diacunar stroke f cerebrovascular

acddents / gmall vessel diseases.

Produktle: Inge ter liak

Vormgeving: Lenting en Terlingen bNO, Mastricht

Druk: Krlps Repro, Meppel

"The publication of this thesis was financially supported by: "Arièns Kappersfonds", Bayer Nederland BV, Boehringer Ingelheim BV, Ciba-Gelgy BV, Dagra Pharma BV, Glaxo BV, Katwijk Farma BV, Merck Sharp \& Dohme BV, Sanof BW and UCB Farma Nederland, BV. 
De taak der wetenschap is, feiten woor schijn en bewijzen voor indrukken in de plaats te stellen.

John Ruskin, 1819-1900

Ter nagedachtenis aan mijn vader Aan mijn moeder Voor Inge 



\section{Contents}

List of abbreviations

General introduction

Chapter 1

Introduction

Lacunar infarcts

16

Lacunar hypothesis

16

Pathogenesis of lacunar infarction

18

Clinical syndromes

19

Leuko-araiosis

Chapter 2

Lacunar infarcts; natural history and validity of the clinical syndromes

\section{Chapter 3}

Isolated monoparesis is not a lacunar syndrome

\section{Chapter 4}

Cardiac and carotid embolism are unlikely causes of lacunar infarction

\section{Chapter 5}

Leuko-araiosis and lacunar infarcts usually result from small vessel disease

\section{Chapter 6}

Two clinically distinct lacunar stroke entities

\section{Chapter 7}

Large subcortical infarcts are not lacunar

\section{Chapter 8}

The course of corticospinal, thalamocortical ${ }_{r}$ and cerebellar pathways in man inferred from lacunar infarct patients

\section{Chapter 9}


$\begin{array}{lr}\text { Summary } & 95\end{array}$

$\begin{array}{lr}\text { Samenvatting } & 99\end{array}$

Appendix

Definition of lacunar syndromes

References

List of publications

Acknowledgements

Curriculum vitae 


\section{List of abbreviations}

$\begin{array}{ll}\text { ADL } & \text { Activities of Daily Life } \\ \text { AH } & \text { Ataxic Hemiparesis } \\ \text { BI } & \text { Betrouwbaarheids Interval } \\ \text { CI } & \text { Confidence Interval } \\ \text { CT } & \text { Computed Tomography } \\ \text { ICA } & \text { Internal Carotid Artery } \\ \text { MRI } & \text { Magnetic Resonance Imaging } \\ \text { NS } & \text { Not Significant } \\ \text { OR } & \text { Odds Ratio } \\ \text { PMS } & \text { Pure Motor Stroke } \\ \text { PSS } & \text { Pure Sensory Stroke } \\ \text { SD } & \text { Standard Deviation } \\ \text { SMS } & \text { Sensorimotor Stroke }\end{array}$




\section{General introduction}

Cerebrovascular diseases are important for society in general. They are the third most common cause of death, and one of the main causes of permanent disability in the Western world, especially in older people. Cerebrovascular diseases are a heterogeneous group of disorders. Prevention, management, and treatment should be directed towards pathophysiologically defined subgroups. One of these subgroups includes the lacunar infarcts, small infarcts located deeply in the brain, or in the brainstem. Among all patients with cerebrovascular disease, about $80 \%$ have cerebral infarction, ${ }^{11,102}$ of which lacunar infarcts constitute up to $25 \%$, representing a numerically important subgroup. In the Netherlands, each year about 20,000 patients suffer a cerebral infarct, ${ }^{102}$ of whom at least 5000 will have a lacunar infarct.

The aim of this thesis is to describe some clinical and radiological aspects of lacunar stroke in a well-defined prospective series of patients with a lacunar infarct, who were registered between July 1987 and August 1989 in a prospective registry at the University Hospital of Maastricht of all patients with a first-ever supratentorial brain infarct with symptoms lasting longer than 24 hours. Furthermore, it was tried to establish whether lacunar infarction should be considered as a separate subgroup among cerebral infarction by studying various clinical aspects of lacunar infarcts in comparison with infarcts involving the cerebral cortex.

The lacunar hypothesis* presumes, firstly, that lacunar infarcts can usually be recognized from specific so-called lacunar syndromes, and, secondly, that they are usually caused by a distinct vasculopathy of the small perforating arteries. ${ }^{8}$ However, the overall clinical usefulness of the lacunar syndromes in diagnosing lacunar infarction has not been definitely established. We therefore determined the validity of the lacunar syndromes in diagnosing lacunar infarction (Chapters 2 and 3).

The second part of the lacunar hypothesis is more difficult to establish. Small vessel vasculopathy can only be assessed with certainty at autopsy. However, there are only few pathological studies, because of the low early case fatality rate. Pathogenesis has therefore to be further elucidated indirectly from clinical studies, by looking at the vascular risk factor profile, and by determining the frequency of potential cardiac sources of embolism and carotid occlusive disease in patients with lacunar infarction (Chapter 4). Further evidence in favor of small vessel disease as the usual cause of lacunar infarction could come from studying the natural history (Chapter 2): if

"The expression "lacunar hypothesis" in this study means "the hypothesis of lacunar infarcts" The contracted verslon, althowgh linguistically ambiguous, is now commonly used in the litterature 
recurrent infarction is significantly more often lacunar in patients with initial lacunar infarction than in those with an initial cortical infarction, this would suggest different underlying vascular pathologies in lacunar and cortical ischemic stroke. Furthermore, we tested the hypothesis that if lacunar infarction and leuko-araiosis are both caused by small vessel disease, leuko-araiosis would be more prevalent in patients with lacunar infarction than in patients with infarction involving the cortex (Chapter 5).

We also investigated whether lacunar stroke patients with one or more asymptomatic lacunar infarcts, and those with only a symptomatic lacunar infarct represent two distinct clinical entities, reflecting the two types of small vessel disease found at autopsy, lipohyalinosis and microatheromatous disease respectively (Chapter $6)$.

Some studies on lacunar infarction described large subcortical infarcts which were called "giant" or "super" lacunes, suggesting that their clinical presentation and pathogenesis are similar to those in lacunar infarcts. However, others reported features of these infarcts which were contradictory to a lacunar cause. Therefore, to determine whether clinical presentation and pathogenesis of large subcortical infarcts resemble those of lacunar infarcts or infarcts involving the cortex, the clinical syndrome, risk factor profile, frequency of potential cardiac sources of embolism, and frequency of significant carotid stenosis were compared between these different infarct groups (Chapter 7).

Using detailed computed tomography (CT) findings, the locations of the small infarcts were correlated with the clinical syndromes, in order to determine the course of the corticospinal, thalamocortical and cerebellar pathways, which are involved in causing the signs of lacunar infarction (Chapter 8). A patient with ataxic hemiparesis following lacunar infarction of the ventrolateral nucleus of the thalamus is described, demonstrating that the ventrolateral part of the thalamus takes part in the cerebellar projection to the sensorimotor cortex (Chapter 9).

In summary the aims of this thesis are:

1. to review the relevant literature on lacunar infarction (Chapter 1);

2. to establish the clinical value of the lacunar syndromes in diagnosing lacunar infarction (Chapter 2);

3 . to describe the natural history and type of recurrent infarction in patients with lacunar infarction (Chapter 2);

4. to assess whether acute isolated monoparesis should be considered a lacunar syndrome (Chapter 3);

5. to study indirectly whether lacunar infarcts are usually caused by small vessel. disease, by determining the frequency of potential cardiac sources of embolism, and large vessel occlusive disease in patients with lacunar infarction (Chapter 4);

6. to determine whether any specific vascular risk factor is involved in the pathogenesis of lacunar infarction (Chapter 4);

7. to assess the frequency of leuko-araiosis in patients with lacunar infarction in order to see whether small vessel disease underlies both lacunar infarcts and leukoaraiosis (Chapter 5);

8. to investigate whether two lacunar stroke entities can be distinguished during life 


\section{(Chapter 6);}

9. to establish the clinical syndrome and pathogenesis of large subcortical infarcts (Chapter 7); and

10. to infer the course of corticospinal, thalamocortical and cerebellar pathways by correlating locations of lacunar infarcts with lacunar syndromes (Chapters 8 and 9). 


\section{Introduction}

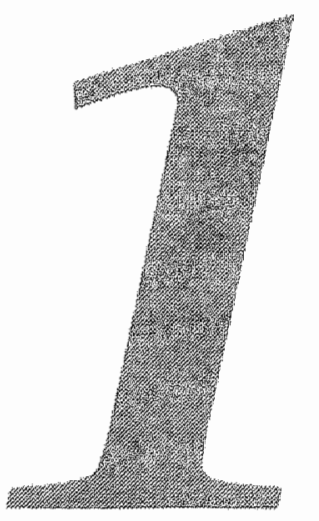




\section{Lacunar infarcts}

Lacunar infarcts or lacunes are small ischemic infarcts located in the deep parts of the brain, or in the brainstem. ${ }^{59}$ The term lacune (from the Latin word lacuna) refers to the cavity or hole that remains after the infarcted tissue has been removed by macrophages. ${ }^{118,152-154}$ The historical aspects of lacunes have recently been reviewed extensively. ${ }^{59,168}$ The first reports on lacunes emerged from France where the term lacune was introduced by Dechambre in $1838 .{ }^{44}$ In 1901 Pierre Marie described the clinical features in 50 cases with lacunar infarcts and introduced the term "état lacunaire" or lacunar state. ${ }^{142}$ Interest in lacunes revived again after the clinicopathologic studies of Fisher $\mathrm{r}^{60-64,67-69,150}$ and after the introduction of $\mathrm{CT}$ and magnetic resonance imaging (MRI).

Lacunar infarcts are caused by occlusion of one single, small, deep perforating or penetrating artery. ${ }^{64}$ These penetrating branches arise directly from the large cerebral arteries (Fig.1.1). ${ }^{152,153}$ They are endarteries, which means that they have no collaterals, although rare anastomoses between them have been described. ${ }^{83,144,180}$ The following groups of penetrators can be distinguished ${ }^{43,152,201,2022}$. the medial striate arteries, including the recurrent artery of Heubner, which branch from the anterior cerebral artery; the lateral striate arteries which branch from the middle cerebral artery; the anterior choroidal artery and additional small branches from the internal carotid artery; the thalamoperforant arteries (thalamotuberal, thalamoperforate, thalamogeniculate and posterior choroidal arteries) which are branches of the posterior cerebral artery; and paramedian branches of the basilar artery. The size of the lacunes ranges from approximately 0.5 to $15 \mathrm{~mm}$ in diameter ${ }^{59}$ and from 0.36 to $6 \mathrm{ml}$ in volume, ${ }^{69}$ depending on the territory supplied by the occluded artery. ${ }^{154}$ At autopsy, the diameter of the involved artery varies between 0.04 and $0.8 \mathrm{~mm} \cdot{ }^{64,68}$ The size of the lacune is generally related to the size of the involved penetrating artery and to the site of the occlusion. ${ }^{152}$ More proximal occlusions result in larger infarcts, because most penetrating arteries branch one or more times. ${ }^{118.152}$

Lacunar infarcts are mainly located in internal capsule and corona radiata, lentiform nucleus (mainly putamen), thalamus, caudate nucleus and pons. ${ }^{59}$ Since the introduction of $\mathrm{CT}$, most lacunar infarcts can easily be visualized. However, CT has the limitation that small lacunes may be missed, ${ }^{152,169,217}$ especially in the posterior fossa. In two studies with serial CT scanning, about $70 \%$ of the clinically suspected lacunar infarcts were visualized. ${ }^{52,120}$ MRI seems to be superior to $\mathrm{CT}$ in detection of lacunar infarcts, ${ }^{27,182}$ especially in the posterior fossa, ${ }^{21,92,125,193}$ although the specificity of MRI is lower. At present, low availability of MRI limits its use in general clinical practice.

\section{Lacunar hypothesis}

The lacunar hypothesis presumes, firstly, that lacunar infarcts can usually be recognized from specific clinical syndromes, and, secondly, that they are usually caused by a distinct vasculopathy of the small perforating arteries. ${ }^{8,148}$ The foundation of the first 


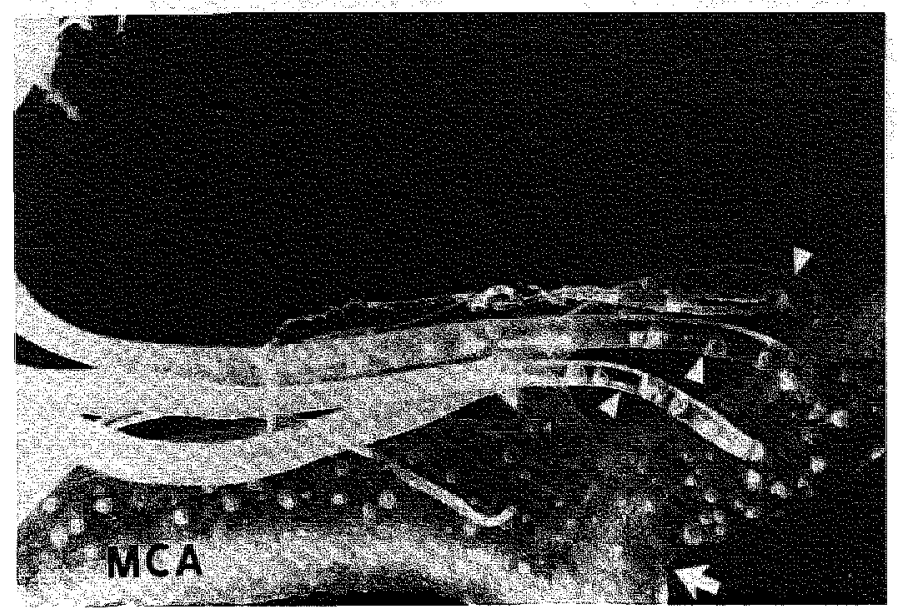

Figure 1.1 Plastic cast (magnification 11x) showing some perforating branches (black and white arrowheads) arising, with almost right angles, from the middle cerebral artery (MCA). White arrow indicates division of MCA (from Marinkovic et al. ${ }^{143}$ ).

part of the hypothesis was laid in some clinicopathological studies, mainlly by Fisher, done on a small number of autopsied cases. $39,40,600-63,65,67-69,71,105,133,150,176,177$ In these studies, autopsy confirmed lacunes in cases of pure motor stroke (PMS), $39,40,60,65,69,105,133,177$ pure sensory stroke (PSS), ${ }^{61,67,71}$ ataxic hemiparesis (AH) ${ }^{62,63,68}$ (including dysarthriaclumsy hand syndrome and homolateral ataxia and crural paresis), and sensorimotor stroke (SMS). ${ }^{69,150,176}$ Many other lacunar syndromes have been reported ${ }^{70,109,122,184}$ but they are uncommon and lack clinicopathological correlation.

Although the spatial resolution capacity of CT is limited, many CT studlies in patients with one of these four lacunar syndromes showed compatible lacunar infarcts. The clinical value of the lacunar syndromes in diagnosing lacunar infarction has been questioned, because CT showed a pathologic heterogeneity (cortical infarcts, hemorrhage or non-vascular causes) in patients with these syndromes. $13,15,23,40,51,72,78,82,88,100,110,126,130,135,138,155,156,161,169,172,179,183,189,191,204,208,210,213,216.21$ Most of these studies were single case reports or comprised only a small number of patients. Recently the clinical usefulness of the lacunar syndromes was further substantiated in a large community-based study. ${ }^{7}$ In this study, only 6 of 108 patients $(6 \%)$ with a lacunar syndrome had a lesion not compatible with occlusion of one single perforating artery, yielding a positive predictive value of $94 \%$. However, sensitivity, specificity and negative predictive value of the lacunar syndromes in diagnosing lacunar infarction could not be assessed. No single study determined the overal] validity of the syndromes in diagnosing lacunar infarction. Obviously, more large clinical studies are needed to establish the clinical usefulness of the lacunar syndromes in diagnosing lacunar infarction.

The second part of the hypothesis concerns the pathogenesis of lacunar infarction, stating that lacunar infarcts are usually caused by a distinct vasculopathy of the small perforating arteries. This part of the hypothesis has been generated from a small number of autopsy studies by Fisher ${ }^{64,65,67,69}$ and is further discussed in the next section. 


\section{Pathogenesis of lacunar infarction}

Several pathogenetic mechanisms explaining lacunar infarcts have been proposed in the past 20 years. The most valuable hypothesis was introduced by Fisher and was mainly derived from two pathological studies. ${ }^{64}, 69$ Fher hypothesized that occlusion of a small perforating artery is caused by a specific small vessel disease. He described two distinct small vessel vasculopathies. The first one is lipohyalinosis, affecting the smaller penetrating arteries (below $0.2 \mathrm{~mm}$ in diameter). ${ }^{4}$ He suggested that this vasculopathy is related to chronic hypertension, ${ }^{64152}$ and that it accounts for many of the smaller lacunes, especially those that are clinically asymptomatic ${ }^{64154}$ Lipohyalinosis consists of segmental vessel wall destruction with fibrinoid and collagen deposits in the arterial vessel wall and eventually superimposed thrombotic occlusion. ${ }^{6}$ A related condition is fibrinoild necrosis or degeneration, occurring in patients with severe "malignant" hypertension, ${ }^{38}$ and found in cerebral, retinal and renal arteries.

A second vasculopathy, different from lipohyalinosis, was described in patients with larger symptomatic lacunes. ${ }^{35,64-67,69}$ In this vasculopathy, microatheroma narrowed or occluded the penetrating artery proximally at its orifice, sometimes with a superimposed thrombus. ${ }^{69}$ These microatheroma are believed to be the most frequent cause of single, symptomatic lacunes. 80,154 According to Fisher, these small vessel vasculopathies, especially lipohyalinosis, result from hypertension. However, more recent studies showed that not every patient with lacunar infarction had hypertension. ${ }^{81 i j}$ Besides the small vessel vasculopathy, other pathogenetic mechanisms have been proposed. Microembolism was suggested by fisher in two cases because the arteries supplying the infarct were patent and intact, but an embolic source was not found. ${ }^{69}$ Potential cardiac and carotid sources of embollism have been suggested in some clinical studies, ${ }^{23,80,138,161,169 ;, 189}$ but in other studies these sources of embolism were infrequent. ${ }^{119,137^{163}, 205}$ Definite conclusions about the role of embolism in. lacunar infarction cannot be drawn, due to these contradictory findings and methodological shortcomings of some of these studies. ${ }^{80,119,161,163,169,189,205}$ At present lacunar infarction is most probably caused by the two described forms of small vessel vasculopathies, but embolism cannot be ruled out definitely. This is in large part due to the lack of neuropathological studies and scarcity of large prospective clinical studies.

The diameter of lacunar infarcts does usually not exceed $15 \mathrm{~mm}^{\text {s9 }}$ but Fisher described also large lacunar infarcts, so-called "giant" or "super" lacunes, "putaminocapsulo caudate infarcts", or capsular infarcts. ${ }^{59,60,69}$ Others called them striatocapsular infarcts " Terms like "giant" or "super" lacunes suggest that these large subcortical infarcts have similar pathogenesis as lacunar infarcts. However, in studies on these large subcortical infarcts, $1,16,134,189,215$ most patients had a potential cardioembolic source or large vessel occlusive disease, features that argue against small vessel disease as usual cause. However, these studies do not allow definite conclusions about the pathogenesis of large subcortical infarcts. 


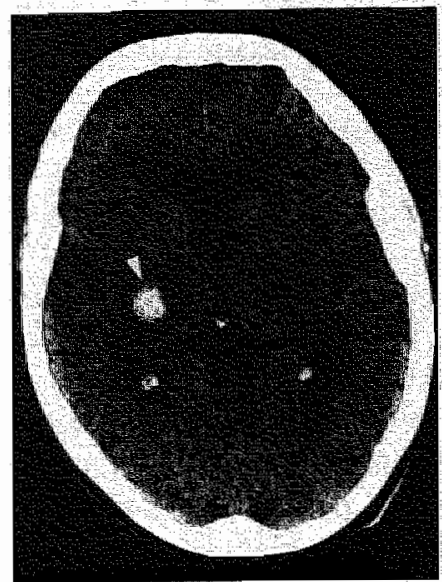

Figure 1.2 CT scan of a 78 year old patient with a lacunar syndrome (SMS) showing a small hemorrhage in the posterior limb of the right internal capsule (arrow).

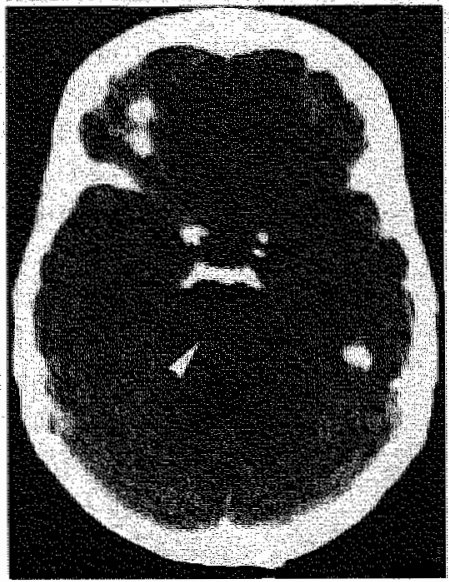

Figure $1.3 \mathrm{CT}$ scan of a 71 year old patient with a PMS showing a lacunar infarct in the pons on the right side (arrow).

\section{Clinical syndromes}

Usually, patients with symptomatic lacunar infarction present clinically with one of the lacunar syndromes, ${ }^{60-63,68,70,150}$ which are composed of focal symptoms and signs present at the time of maximal deficit, following a single, focal cerebrovascular event. ${ }^{7}$ The presence of a visual field deficit, evidence of higher cerebral dysfunction (e.g. dysphasia, visuospatial disturbance, apraxia, agnosia or neglect) or features that clearly localize the lesion to the brainstem (except nystagmus or dysarthria) exclude the diagnosis of a lacunar syndrome. ${ }^{7,70}$ However, in rare instances patients with lacunar infarction may have dysphasia or neglect. $12,20,31,57,70,203,209$ Moreover, lacunar syndromes have also resulted from cortical infarcts, hemorrhage or non-vascular causes (Fig. 1.2) $13,15,23,40,51,72,78,82,88,100,110,126,130,135,138,155,156,161,169,172,179,183,189,191,204,208,210,213$, 216218 but mostly as single cases.

Pure motor stroke(PMS) is the most frequent lacunar syndrome. It was defined by Fisher and Curry in 1965 as a complete or incomplete paralysis of the face, arm and leg on one side and unaccompanied by sensory signs, visual field defect, dysphasia, apraxia, agnosia, vertigo, deafness, tinnitus, diplopia, cerebellar ataxia, or gross nystagmus. ${ }^{60}$ Initially, subjective sensory symptoms might be present, but there should not be any objective sensory loss on standard clinical testing. " Some patients have dysarthria. Based on subsequent reports, ${ }^{52,172}$ partial syndromes with faciobrachial or brachiocrural weakness were also included. ${ }^{7}$ Isolated monoparesis was not considered as a lacunar syndrome, because Fisher suggested that the more restricted the neurological deficit, the more likely it had resulted from a cortical lesion. ${ }^{8,60}$ However, 
no single study determined prospectively whether monoparesis is usually caused by cortical rather than lacunar infarction. PMS can be caused by lacunar infarction anywhere along the corticospinal pathway from the cerebral cortex to the medullary pyramid. ${ }^{60}$ The syndrome is usually caused by lacunes in internal capsule, ${ }^{52,60,161,172,216,217}$ corona radiatat ${ }^{52,61,216}$ or pons (Fig.1.3) ${ }^{60,499}$ but lacunes in lentiform nucleus, ${ }_{f}{ }^{161,217}$ cerebral peduncle ${ }^{105}$ and medullary pyramid, ${ }^{39,133,177}$ have also been described.

Pure sensory stroke (PSS) consists of persistent or transient numbness and/or sensory loss in one side of the body, including face, arm and leg, without weakness, vertigo, diplopia, dysarthria, dysphasia, visual field defect, nystagmus or memory loss. ${ }^{.11}$ Patients without objective sensory loss on examination were also considered to have suffered a PSS. ${ }^{7,61,71}$ Faciobrachial or brachiocrural deficits were also included. ${ }^{7,8}$ Originally, Fisher found lacunes in the thalamus (ventral posterolateral part) at autopsy. ${ }^{61,67}$ Usually $\mathrm{CT}$ shows no infarct, because the lesions are probably too small to be visualized, ${ }^{17}$ but lacunes have been found on CT in the thalamus, ${ }^{86,131,176,185}$ and thalamocapsular region; ${ }^{216}$ and on MRI in the pons, ${ }^{106}$ and thalamus. ${ }^{185}$

Ataxic hemiparesis (AH) is a syndrome of hemiparesis and cerebellar-type ataxia on the same side of the body. ${ }^{62.68}$ On examination, ataxia is out of proportion to the degree of weakness. The syndrome was originally described as homolateral ataxia and crural paresis. ${ }^{62}$ It also includes so-cailed dysarthria-clumsy hand cases ${ }^{63}$ The syndrome is due to interruption of corticospinal and either cerebellarcortical or corticocerebellar pathways. AH may follow lacunar infarction in the contralateral corona radiata, the posterior limb of the internal capsule, or the pons (Fig.1.4). $28,45,47,52,58,90,100,108,112,114,116,117,127$. $161,167,187,195,207,214,217$

In sensorimotor stroke (SMS), unilateral motor and objective sensory loss exists, , , 150 including faciobrachial or brachiocrural deficits due to interruption of both corticospinal and thalamocortical pathways. Originally only a few patients with SMS due to CT or autopsy proven lacunar infarction have been described. ${ }^{70,150,176} \mathrm{In}$ the first reported case of SMS, a lacunar infarct was found in the ventral posterolateral nucleus of the thalamus, while the adjacent internal capsule showed some pallor (thalamocapsular ischemia). ${ }^{150}$ Initially, SMS was not regarded as a lacunar syndrome because it was considered unlikely that involvement of both thalamus and internal capsule, which are supplied by separate subsets of penetrators, could result from the occlusion of one single perforating artery. However, vascular connections between thalamus and internal capsule have been demonstrated, ${ }^{201,202}$ whereas $C T$ revealed lacunes in thalamocapsular region ${ }_{\Downarrow}^{10,176}$ anterior and posterior limb of internal capsule, ${ }^{110}$ lentiform nucleus extending up to the corona radiata ${ }^{52}$ caudatoputaminalcapsular region, ${ }^{217}$ and corona radiata (Fig.1.5)..10 


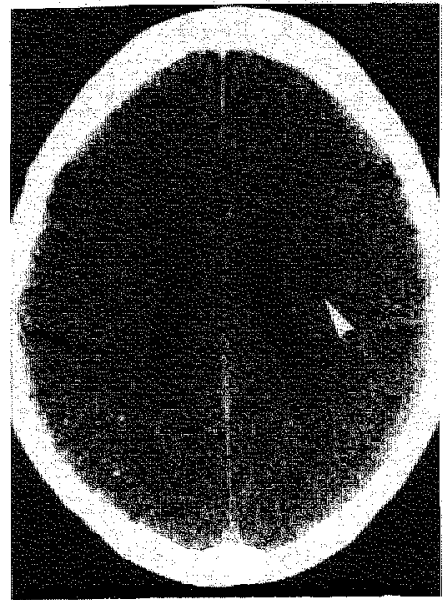

Figure $1.4 \mathrm{CT}$ scan of a 67 year old patient with a AH showing a lacunar infarct in the left corona radiata (arrow).

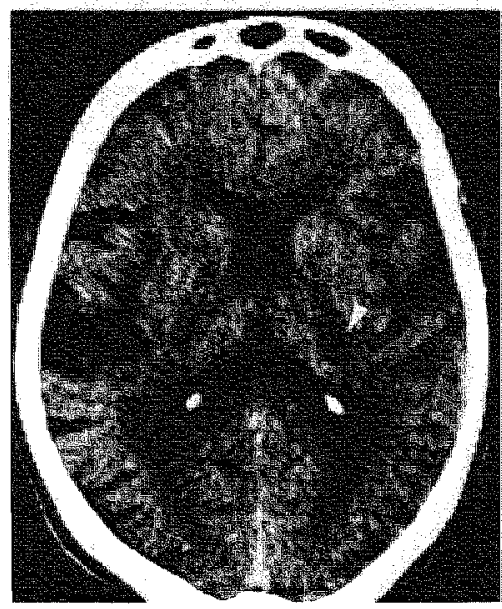

Figure $1.5 \mathrm{CT}$ scan of a 76 year old patient with a SMS showing a lacuriar infarct in the posterior limb of the left internal capsule (arrow).

\section{Leuko-araiosis}

The term leuko-araiosis (from the Greek words leuko and araiosis, which mean white and rarefaction ${ }_{r}$ respectively) was introduced by Hachinski and colleagues ${ }^{91}$ for the periventricular diffuse white matter lucencies of undetermined origin on CT (Fig.5.1). These white matter lucencies were originally attributed to subcortical arteriosclerotic encephalopathy or Binswanger's disease,,$^{32,113,124,139,140,170,178}$ but they have also been described in normal subjects, ${ }^{113,173,197}$ in patients with stroke ${ }^{22}$ or with vascular risk factors, and in dementia of the Alzheimer's type. ${ }^{29,79,113,173,198}$ Autopsy in patients with leuko-araiosis showed small vessel disease with hyalinization and segmental fibrinoid arterial degeneration of the small perforating arteries, lacunes, cystic lesions and demyelination. ${ }^{32,50,79,87,124,140,178}$ Some of these cystic lesions have the same histologic characteristics as lacunar infarcts, whereas others could be considered as dilatation of perivascular spaces. The small vessel disease resembles lipohyalinosis. Therefore, according to autopsy data, lipohyalinosis seems to be involved in the pathogenesis of leuko-araiosis. The small vessel vasculopathy probably leads to chronic ischemia in the arterial border zones resulting in demyelination and gliosis of the periventricular white matter, visible as leuko-araiosis on CT. 



\section{Lacunar infarcts; natural history and validity of the clinical syndromes}





\section{Introduction}

Lacunar infarcts constitute up to $25 \%$ of all ischemic strokes, forming a numerically important subgroup. ${ }^{7,23,89,129,151,174}$ It is important to define their pathogenesis and natural history, because they may warrant treatments different from infarcts involving the cerebral cortex. ${ }^{194,219}$

The lacunar hypothesis suggests, firstly, that symptomatic lacunar infarcts usually present with specific so-called lacunar syndromes, and, secondly, that they are usually caused by a distinct vasculopathy of the small perforating arteries. ${ }^{8} \mathrm{~A}$ prospective community-based study substantiated the first part of the hypothesis by determining the positive predictive value of the lacunar syndromes, ${ }^{7}$ but sensitivity, specificity and negative predictive value could not be assessed. However, others still question the clinical value of the lacunar syndromes because case reports have associated them with a range of pathologies on CT, e.g. cortical infarcts, hemorrhage or non-vascular causes. $4,23,161,172,216$ To our knowledge, no single study has been attempted to determine the overall validity (sensitivity, specificity and predictive values) of the lacunar syndromes in diagnosing symptomatic lacunar infarction.

The second part of the lacunar hypothesis is more difficult to investigate. There are only a few pathological studies because of the low early case fatality rate ${ }^{64,69} \mathrm{~A}$ recent community-based study suggested that very few lacunar infarcts are likely to be caused by cardiac embolism, ${ }^{137}$ and artery-to-artery embolism from the carotid artery is also an unlikely cause, ${ }^{119,163,205}$ thus suggesting indirectly that small vessel disease is the most likely cause. Further evidence could come from studying the natural history of lacunar infarcts: if recurrent infarction would significantly more often be lacunar in patients with initial lacunar infarction than in those with an initial cortical infarction, this would suggest different underlying vascular pathologies in lacunar and cortical ischemic stroke. In the only natural history study of lacunar infarction, recurrent infarcts could not reliably be classified.?

In the present study we established the validity (sensitivity, specificity and predictive values) of the lacunar syndromes in diagnosing lacunar infarction, using a prospective, hospital-based registry of all first-ever supratentorial brain infarcts, we compared the natural history of patients with lacunar and cortical infarets, and we tested the hypothesis that in case of two distinct vascular pathologies in lacunar and cortical infarction, recurrent infarcts would be of the same subtype as the first one.

\section{Patients and methods}

The patients were registered between July 1987 and August 1989 in a prospective registry at the University Hospital of Maastricht of all patients with a first-ever supratentorial brain infarct with symptoms lasting longer than 24 hours. The University Hospital is the only hospital in Maastricht with an adherent population of 180,000 people. All patients were examined as soon as possible after admittance.

Routine investigations included standard blood and urine tests, electrocardiography, chest radiography, non-invasive carotid studies, and CT. Echocardiography, 
24 hour-electrocardiographic (Holter) monitoring and cerebral angiography were performed in selected cases.

Brain infarction was defined as rapidly developing clinical signs of focal disturbance of cerebral function, lasting longer than 24 hours or leading to death, with no apparent cause other than that of vascular origin, ${ }^{9,95,102}$ while CT showed an area of low attenuation compatible with the clinical signs and symptoms or with no specific lesion on $C T$, or when autopsy revealed an infarct compatible with the clinical symptoms and signs. ${ }^{7}$ When neither CT nor autopsy were available, we used the Guy's Hospital Stroke Diagnostic Score (Allen score) to predict the probability that the stroke was due to infarction. ${ }^{2}$ Probable infarction was diagnosed when the score was lower than 4 , i.e. the probability that the stroke was due to infarction was larger than $90 \%{ }^{2,7}$

Two types of infarction were distinguished: lacunar infarction, and infarction involving the cortex. Lacunar infarction was defined as a case of a lacunar syndrome in which CT findings were compatible with cerebral infarction due to occlusion of one single perforating artery ${ }_{f}{ }_{i}$ i.e. a subcortical, small, sharply marginated hypodense lesion with diameter smaller than $20 \mathrm{~mm}$, or if no specific lesion was visible on CT. We distinguished four lacunar syndromes: pure motor stroke (PMS), sensorimotor stroke (SMS), pure sensory stroke (PSS) and ataxic hemiparesis (AH; including dysarthria-clumsy hand cases) ${ }^{7,70}$ (see also Appendix).

Infarction involving the cortex was defined as a case of a cortical syndrome, i.e. a unilateral motor or sensory deficit, or both, in combination with signs of cortical dysfunction (e.g. aphasia, visual field deficit, visual spatial disturbances, apraxia, neglect or agnosia), in which CT findings or autopsy were compatible with infarction involving the cortex, or if no specific lesion was visible on CT. Patients with large subcortical infarction were also included in this group, because pathogenesis is similar to infarction involving the cortex ${ }^{16,134,189}$ (see also Chapter 7). Infarcts involving the cortex were divided into three groups by presumed cause: cardioembolic, atherothrombotic, and rare etiologies. Cardioembolic infarction was defined as an infarct involving the cortex in the presence of one of the following cardiac sources of embolism: atrial fibrillation (chronic, paroxysmal), recent myocardial infarction (less than 6 weeks), prosthetic aortic or mitral valve, endocarditis, cardiomyopathy, mitral. stenosis, left ventricular aneurysm, and intraventricular thrombus. Atherothrombotic infarction was defined as an infarct involving the cortex, with no other apparent cause than large vessel disease, i.e. atherothrombosis or artery-to-artery embolism. The last group contained cases with rare etiologies, such as vasculitis, arterial dissection, fibromuscular dysplasia and hematologic disorders.

The follow-up of patients with lacunar infarction was compared with that of patients with atherothrombotic infarction. Patients with cardioembolic infarction were excluded from this analysis because we wanted to compare cerebral small vessel disease and (pre-) cerebral large vessel disease. Furthermore, concomitant cardiac disease would incidentally affect the natural history of cardioembolic infarction adversely. The patients were followed prospectively by one of the neurologists of our department, and were seen every 3 to 6 months. Special attention was paid to the type of recurrent infarction or cause of death. Handicap was measured using the modified 
Table 2.1 Distribution of lacumar syndrones and CT findings in 109 patients presenting with a lacunar syndrome.

\begin{tabular}{lcccc}
\hline Syndrome & $\begin{array}{l}\text { Number of } \\
\text { patients }\end{array}$ & No infarct & $\begin{array}{l}\text { Lacuinar } \\
\text { infarct }\end{array}$ & $\begin{array}{l}\text { Other } \\
\text { lesion }\end{array}$ \\
\hline PMS & 50 & 21 & 22 & 7 \\
SMS & 40 & 16 & 20 & 4 \\
AH & 17 & 3 & 14 & - \\
PSS & 2 & 1 & 1 & - \\
Total & 109 & 41 & 57 & 11 \\
\hline
\end{tabular}

Rankin scale. ${ }^{10,171,200,206,211}$ Patients with Rankin grade 0, 1 and 2 were considered independent; grade 3, 4 and 5 were considered dependent.

Although it has recently been established that there is no bias from accompanying patient information in detection of lacunar infarction in brain CT scans, ${ }^{25} \mathrm{CT}$ scans were independently reviewed by two neurologists without knowledge of the clinical syndrome. In case of disagreement on the presence of an infarct, CT was regarded as negative. There was no disagreement on the distinction of lacunar and non-lacunar infarcts.

Proportions are given with $95 \%$ confidence intervals (CI). ${ }^{77}$ Validity of the lacunar syndromes in diagnosing lacunar infarction were determined by assessing sensitivity, specificity and predictive values. ${ }^{186}$ Survival rate and the risk of recurrent infarction were determined using Kaplan-Meier estimation techniques, with Breslow (generalized Wilcoxon) testing. ${ }^{17}$ Dichotomous variables were analyzed using odds ratios (OR) with $95 \% \mathrm{CI},{ }^{157,188}$ and chil-squared test with Yates correction.

\section{Results}

From 1. July 1987 until 1 August 1989,252 patients with a first-ever supratentorial brain infarct were registered. Mean time between onset of symptoms and examination was 2 days (range: $0-14$; two patients were examined after 30 days).

One hundred and nine patients (43\%; 95\% CI 37-49\%) had a lacunar syndrome; all patients had CT scan. Eighty percent of the patients with lacunar infarction had CT within one week and $93 \%$ within two weeks after admission. Of the 46 patients with a normal first CT, 29 had a second CT which showed a lacunar infarct in five. Distribution of lacunar syndromes and CT findings are given in Table 2.1. A lacunar infarct on CT was seen in 57 patients ( $52 \%$; Table 2.1). Eleven patients (7 PMS, 4 SMS; 10\%) had no lacunar infarct but an infarct involving the cortex on CT compatible with the symptoms, nine of which were located in the right hemisphere. These eleven patients were included in the cortical infarction group.

One hundred and forty-three patients presented with a cortical syndrome. Seven of these patients (5\%) had neither CT nor autopsy, but an Allen score lower than 4 . 
Table 2.2 Sensitivity, specificity and predictive values of the lacunar syndromes in diagnosing lacunar infarction.

\begin{tabular}{llll}
\hline & $\begin{array}{l}\text { Cr compatible } \\
\text { with lacinar } \\
\text { infarction }\end{array}$ & $\begin{array}{l}\text { Cr not compatible } \\
\text { with lacunair } \\
\text { infarction }\end{array}$ & Total \\
\hline $\begin{array}{l}\text { Patients with } \\
\text { lacunar syndiome }\end{array}$ & 98 & 11 & 109 \\
$\begin{array}{l}\text { Pattents without } \\
\text { lacurair syndiome }\end{array}$ & 5 & 138 & 143 \\
\begin{tabular}{l} 
Total \\
\hline
\end{tabular} & 103 & 149 & 252 \\
\hline
\end{tabular}

Eighty-five percent of the patients with cortical infarction had CT within one week and $93 \%$ within two weeks. Five patients had no cortical infarct but ipsilateral lacunar infarction on $\mathrm{CT}$, which might have caused the symptoms. These five patients were included in the lacunar infarction group. Thus, in total there were 103 cases of lacunar infarction $(41 \% ; 95 \% \mathrm{CI} 35-47 \%)$, and 149 cases of infarction involving the cortex. Among the 149 patients with infarction involving the cortex, 50 had cardioembolic infarction and 94 atherothrombotic infarction. The group with miscellaneous causes contained five patients, completing the 252 registered patients with a first-ever supratentorial brain infarct.

Sensitivity and specificity of the lacunar syndromes in diagnosing lacunar infarction were $95 \%$ and $93 \%$, respectively. Positive and negative predictive values of diagnosing lacunar infarction in patients with lacunar syndromes were $90 \%$ and $97 \%$, respectively (Table 2.2).

The follow-up of patients with lacunar infarction was compared with that of patients with atherothrombotic infarction. The mean age of patients with lacunar infarction was 67.2 (SD 10.3) years. There were $57 \operatorname{men}(55.3 \%)$. The 94 patients with atherothrombotic infarction had a mean age of 69.7 (SD 13) years. There were $59 \mathrm{men}$ (62.8\%). Mean duration of follow-up was 11 months (range 24 days-26 months) in the patients with lacunar infarction, and 11 months (range 3 days-29 months) in the patients with atherothrombotic infarction.

Survival rates in both groups are given in Fig. 2.1. Patients with lacunar infarction had better survival during follow-up than patients with atherothrombotic infarction $(\mathrm{p}=0.0002)$. One year cumulative survival was $85 \%$ in the lacunar infarction group and $72 \%$ in the atherothrombotic infarction group (OR $3.37 ; 95 \% \mathrm{CI} 1.52-7.48$; $\mathrm{p}<0.05$ ). In the lacunar infarction group, twelve patients died during the follow-up perlod (Table 2.3). Two patients died after one month, resulting in an one-month case fatality rate of $2 \%$. In the atherothrombotic group, 30 patients died during the followup period (Table 2.3). Eleven patients died within one month, due to neurologic sequelae of the infarct, resulting in an one-month case fatality rate of $12 \%$, which is significantly higher than in the lacunar infarction group (OR 0.15; 95\% CI 0.03-0.70; $\mathrm{p}<0.05)$. 


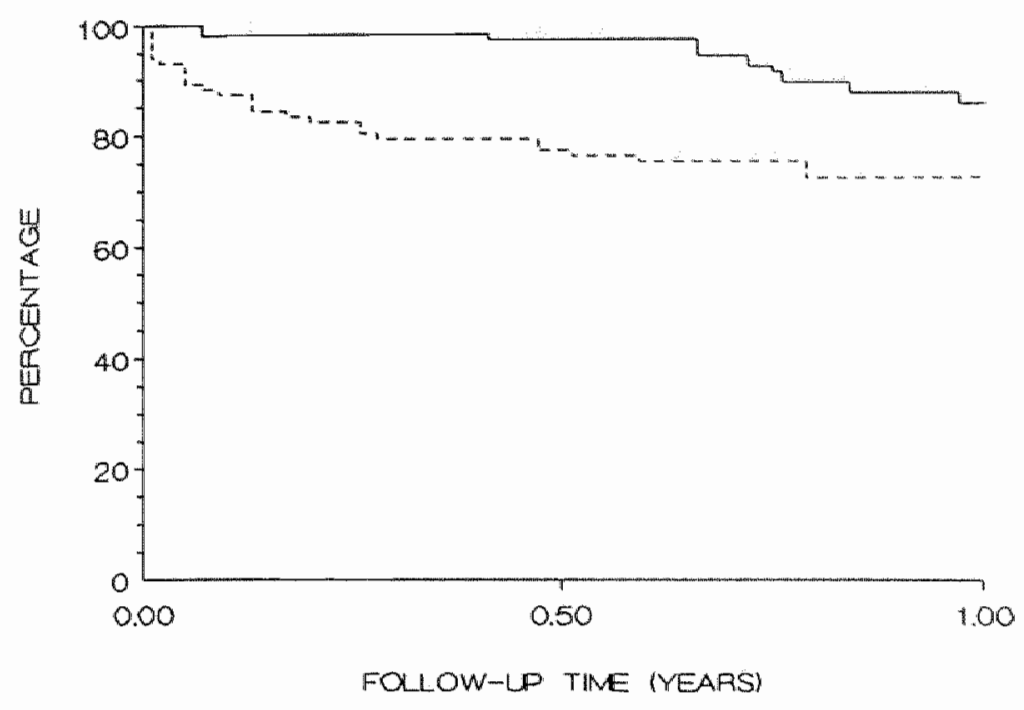

Figure 2.1 Kaplan-Meier curves showing percentage surviving one year after lacunar infarction (solid line) or atherothrombotic infarction (broken line). Survival was better in patients with lacunar infarction $(p=0.0002)$.

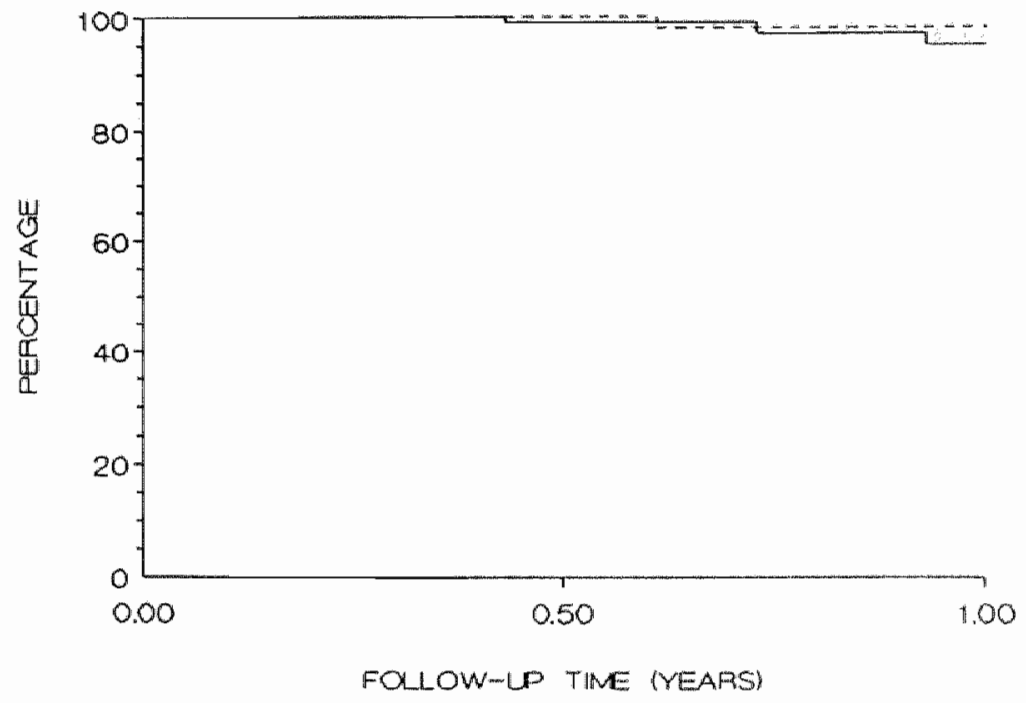

Figure 2.2 Kaplan-Meier curves showing percentage free of recurrent infarction one year after lacunar infarction (solid line) or atherothrombotic infarction (broken line). Risk of recurrent infarction did not differ in both groups $(p=0.08)$. 


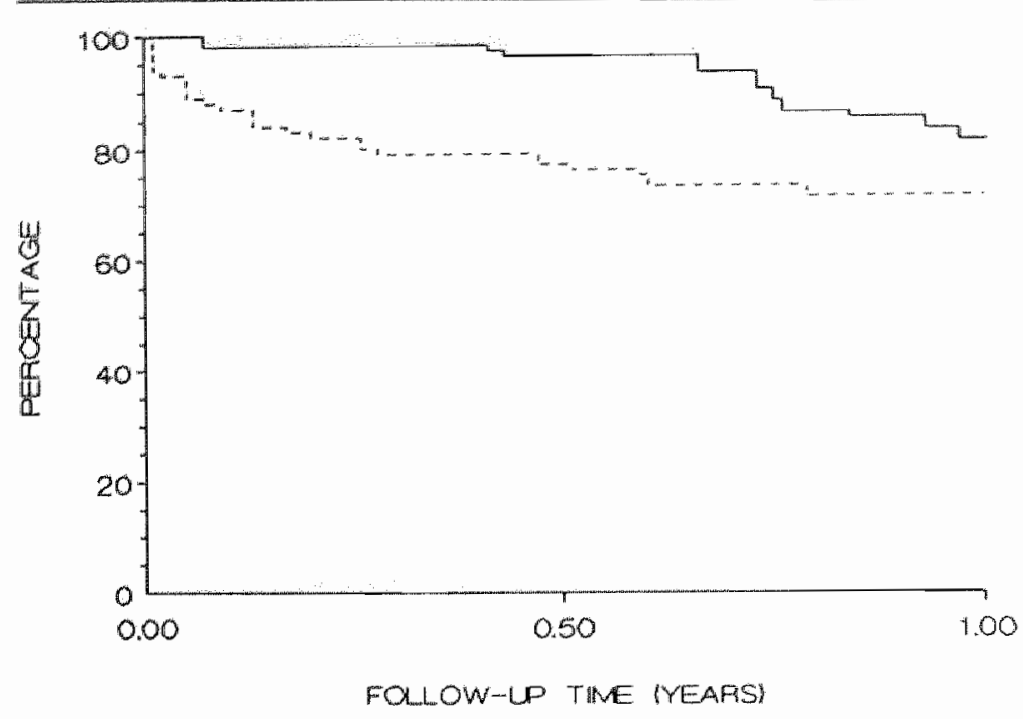

Figure 2.3 Kaplan-Meier curves showing percentage surviving free of recurrent infarction one year after lacunar infarction (solid line) or atherothrombotic infarction (broken line). Survival free of recurrent infarction was better in patients with lacunar infarction $(p=0.002)$.

Risks of recurrent infarction did not differ in both groups ( $p=0.08 ; \mathrm{Fig} .2 .2)$. One-year cumulative risk of recurrence was $5 \%$ in the lacunar infarction group and $2 \%$ in the atherothrombotic infarction group (OR $2.79 ; 95 \% \mathrm{Cl} 0.29-27.10)$. There were seven recurrent infarcts in the lacunar infarction group during the follow-up period. They appeared between 5 and 16 months after stroke. One patient had large hemorrhagic infarction and died of transtentorial coning. The other six patients had a recurrent lacunar syndrome (all PMS), three in the same hemisphere and three in the

Table 2.3 Cause of death in the patients with lacunar and atherothrombotic infarction during mean follow-up of 11 months.

\begin{tabular}{lll}
\hline Cause of death & $\begin{array}{l}\text { Lacusar } \\
\text { infarction } \\
n=12\end{array}$ & $\begin{array}{l}\text { Atherothrombotlc } \\
\text { infarction } \\
\mathrm{n} 30\end{array}$ \\
\hline $\begin{array}{l}\text { Early complications of } \\
\text { infarct ( } 1 \text { month) }\end{array}$ & 1 & 11 \\
$\begin{array}{l}\text { Late complications of } \\
\text { Infarct ( }>1 \text { month) }\end{array}$ & - & 6 \\
$\begin{array}{l}\text { Cardiac } \\
\text { Other } \\
\text { Unknown }\end{array}$ & 3 & 4 \\
\hline
\end{tabular}


Table 2.4 Number of ADL-independent patients on adwission and after 3 to 6 months in lacunar and atherothrombotic infarction. An OR larger than 1 indicates a higher number of patients in the lacumar infarction group.

\begin{tabular}{|c|c|c|c|c|c|}
\hline ADL-independent & $\begin{array}{l}\text { Lacunar } \\
\text { infarction } \\
n=103(\%)\end{array}$ & $\begin{array}{l}\text { Atherothrombotic } \\
\text { untartion } \\
\text { na } 94(\%)\end{array}$ & OH & $95 \% \mathrm{Cl}$ & $\mathrm{p}^{*}$ \\
\hline On admission & $32(31)$ & $15(16)$ & 237 & 1.19. 4.73 & $<0.025$ \\
\hline $\begin{array}{l}\text { After 3-6 } \\
\text { months }\end{array}$ & $85(83)$ & $43(46)$ & 5.60 & $2.93-10.69$ & $<0.001$ \\
\hline
\end{tabular}

* chi-squared test with Yates correction

contralateral hemisphere. In two of five who had CT after recurrence, a new lacunar infarct was seen, whereas three had no new specific abnormalities. In the atherothrombotic infarction group, only two patients had recurrent infarction: one after 7 months and one after 2 years. Both patients had a recurrent cortical syndrome. No CT was performed after these recurrences. Surviving free of recurrent infarction is shown in Fig. 2.3. Patients with lacunar infarction had better survival free of recurrent infarction than patients with atherothrombotic infarction $(p=0.002)$. One year cumulative risk of either dying or having a recurrent infarct or both was $20 \%$ in the lacunar infarction group and $30 \%$ in the atherothrombotic infarction group (OR $2.65 ; 95 \% \mathrm{CI} 1.27-5.54 ; \mathrm{p}<0.05)$.

At the time of admission, $31 \%$ of the patients with lacunar infarction were independent regarding their activities of daily life ( $A D L)$, with no significant differences between the different lacunar syndromes (Table 2.4), whereas at three to six months after stroke (time of first follow-up) $83 \%$ were independent. In the atherothrombotic infarction group, $16 \%$ of the patients were functionally independent on admission, whereas $46 \%$ after three to six months. This means that significantly more patients with lacunar infarction than atherothrombotic cortical infarction were functionally independent at admission and after three to six months.

\section{Discussion}

Lacunar syndromes are clinical syndromes that are usually caused by lacunar infarcts, which usually result from small vessel disease occluding one small perforating artery. ${ }^{7,8,60.64,67-70,150}$ This clinico-pathological correlation was tested and substantiated in a prospective community-based study," in which the four lacunar syndromes of PMS, SMS, PSS and AH were carefully defined, and substantiated by correlation with CT findings. ${ }^{7}$ In that study, only 6 out of 108 patients $(6 \% ; 95 \% \mathrm{CI} 1.3-9.9 \%)$ with a lacunar syndrome had a lesion on CT not compatible with occlusion of one single perforating artery. Others using the same definitions also supported the clinical 
usefulness of the lacunar syndromes. ${ }^{120_{n} 174}$ Patients with lacunar syndromes and normal $\mathrm{CT}$ have often lacunar infarction on $\mathrm{MRI}_{v}^{6,27,182}$ sustaining the assumption that lacunar syndromes with normal CT indeed result from lacunar infarction. Therefore, we used the same definitions as Bamford et al. ${ }^{7}$ Pathologic heterogeneity in patients with lacunar syndromes was reported, ${ }^{4,23,161,172,216}$ but the syndromes in these studies were often not carefully defined. Eleven patients (10\%) with a lacunar syndrome in our study had an infarct involving the cortex. Nine of these infarcts were located in the right, non-dominant hemisphere. Obviously, especially cortical infarcts in the right hemisphere can be confused with lacunar infarcts. This could be explained by the absence of signs of cortical dysfunction in right hemisphere cortical infarcts, or by the fact that subtile cortical signs may be missed on routine neurological examination. Only $5 \%$ of our patients with lacunar infarction were not recognized clinically because they did not present with one of the lacunar syndromes. We found positive and negative predictive values of $90 \%$ and $97 \%$, with a pretest probability of $41 \%$, showing that the lacunar syndromes are a good or even excellent clinical test to diagnose lacunar infarction.

Our data show that $41 \%(95 \% \mathrm{Cl} 35-47 \%)$ of all registered patients with a first-ever supratentorial brain infarct had a lacunar infarct. In other hospital-based studies the percentage of lacunar infarcts among all cases of cerebral infarction varied between 13 and $22 \%{ }^{23,12 \%, 151}$ In two population-based studies about $25 \%$ of all registered patients with cerebral infarction had a lacunar infarct. ${ }^{7,174}$ However, we only registered supratentorial brain infarcts, whereas lacunar infarcts can also occur in the brainstem. The percentage of lacunar infarcts among all types of cerebral infarction, including in the brainstem, would then subsequently be lower. Patients with lacunar infarcts may be underrepresented in hospital-based studies as compared to populationbased studies because having less neurological deficit they may less frequently be referred to hospital. ${ }^{7}$ The actual frequency of lacunar infarction in our population at large might therefore even have been higher. On the other hand, our hospital is the only one in the Maastricht referral area, whereas furthermore only approximately $16 \%$ of stroke patients in the Netherlands are not admitted to hospital. ${ }^{102}$ These are probably mainly rapidly lethal and rapidly reversible strokes, usually representing cerebral hemorrhage and transient ischemic attack (TIA), respectively, both of which are not included in our study. Moreover, the proportion of lacunar stroke in our series is quite similar to that in the community-based Oxfordshire Community Stroke Project," suggesting there is no major referral bias in our study. It is obvious that lacunar infarcts form a numerically important subgroup among patients with cerebral infarction. It is therefore important to distinguish this subgroup in future stroke treatment trials because they may warrant treatments different from cortical infarcts.

About $50 \%$ of the patients with a lacunar syndrome had a lacunar infarct visible on $\mathrm{CT}$. Previous studies report positive $\mathrm{CT}$ for lacunar infarcts in $35-50 \%,{ }^{7,161}$ while serial CT scanning, and the use of $3 \mathrm{~mm}$ CT slices, ${ }^{120}$ increased the detection rate up to $76 \% .^{52,120}$ Five of twenty-nine patients $(17 \%)$ with a negative CT in our study showed a lacune on a second CT scan. Obviously, this low yield does not justify repeated CT scanning in all patients with lacunar stroke just to verify the stroke was 
due to lacunar infarction.

Does the natural history of patients with lacunar infarcts differ from that of patients with atherothrombotic infarcts involving the cortex? One-month case fatality rate was less and survival was better during follow-up in patients with lacunar infarction. "These findings agree with those in a previous study. "Our data of patients with atherothrombotic infarction were in agreement with those for cerebral infarction in general in two previous studies ${ }^{11,107}$ The higher one-month case fatality rate and lower survival in patients with atherothrombotic infarction are caused by deaths due to early (transtentorial coning) and late complications. Risk of recurrent infarction was similar in patients with lacunar and atherothrombotic infarction, although the figures were small. Survival free of recurrent infarction was better in patients with lacunar infarction. More patients with lacunar infarction were ADL-independent on admission as well as after 3-6 months. This was probably due to the absence of cortical dysfunction in the lacunar infarction group. So, our data sustain the general clinical assumption that the natural history in patients with lacunar infarcts is less unfavorable than in patients with atherothrombotic infarcts involving the cortex, with regard to both survival and disability.

Of the seven recurrent infarcts in the lacunar infarction group, six were lacunar again. The two patients with recurrent infarction in the atherothrombotic cortical infarction group, had a cortical syndrome again. These findings support the hypothesis that two distinct vascular pathologies underlie lacunar infarcts and atherothrombotic infarcts involving the cortex: patients with lacunar infarcts suffer from small vessel disease occluding the small perforating arteries; and patients with atherothrombotic infarcts involving the cortex suffer from large vessel disease, with carotid thrombormbolism or local atherothrombosis. This hypothesis does not imply that the two vascular pathologies are mutually exclusive; some patients may suffer from both types of infarction, like our one lacunar patient with a recurrent cortical infarct. Of the six recurrent lacunar infarcts, three were located in the contrala teral hemisphere, suggesting a generalized small vessel disease in both hemispheres. Whether small and large vessel disease are independently different vasculopathies, or whether both result from one vasculopathy of which small vessel disease becomes symptomatic first, ${ }^{7}$ remains to be shown. Another question is how many patients with symptomatic lacunar infarction ultimately develop a lacunar state with corresponding dementia. To answer both these questions, long-term follow-up of lacunar stroke patients is required. 



\section{Isolated monoparesis is not a lacunar syndrome}




\section{Introduction}

Pure motor stroke (PMS), one of the lacunar syndromes, was defined by Fisher and Curry in 1965 as a complete or incomplete paralysis of face, arm and leg on one side of the body. ${ }^{60}$ Later, partial syndromes of brachiocrural or faciobrachial weakness were also included in the definition of PMS, because CT revealed lacunar infarcts in patients with these partial syndromes. ${ }^{7,8}$ Fisher and Curry ${ }^{60}$ suggested that a pure motor monoplegia without accompanying sensory or speech signs could be caused by a cortical infarct involving the motor cortex or by a lacunar infarct in corona radiata, internal capsule or pons. However, monoparesis was not considered as a lacunar syndrome ${ }^{8,60}$ because the more restricted the neurological deficit, the more likely it had resulted from a cortical lesion in the absence of a hemianopia or higher cerebral dysfunction. Later, Fisher stated that a monoplegia is never due to occlusion of a deep penetrating branch. ${ }^{70}$ However, isolated facial weakness, ${ }^{32, t 09}$ brachial weakness, ${ }^{138}$ and crural weakness ${ }^{52,138,172}$ have been described in association with lacunar infarcts on CT. Yet, this does not imply that Fisher's original suggestion that isolated monoparesis usually results from a cortical rather than a lacunar infarct, is incorrect.

So far, no prospective study has determined whether monoparesis is usually due to cortical or lacunar infarction. To assess whether monoparesis is usually secondary to a lacunar or cortical infarct, we determined the site of infarction on CT in patients with isolated monoparesis that were part of a prospective series of 252 patients presenting with their first-ever supratentorial brain infarction.

\section{Patients and methods}

The patients were registered between July 1987 and August 1989 in a prospective registry of all patients with a first-ever supratentorial brain infarct with symptoms lasting longer than 24 hours. One of the aims using such a registry was to establish the validity of the lacunar syndromes by clinical assessment of the patients without knowledge of CT findings.

Isolated monoparesis was defined as paresis of either face, arm, or leg, without signs of cortical dysfunction (e.g. aphasia, neglect, visual field deficit), and with or without sensory disturbances.

Routine investigations included: standard blood and urine tests, electrocardiography, chest radiography, non-invasive carotid studies, and CT. Echocardiography, 24 hour-electrocardiographic (Holter) monitoring and cerebral angiography were performed in selected cases.

The following risk factors were recorded: hypertension (known hypertension treated with anti-hypertensive medication; two or more blood pressure-recordings higher than $160 / 90 \mathrm{~mm} \mathrm{Hg}$ before stroke or at least one week after stroke), diabetes mellitus (known diabetes treated with diet and/or medication; fasting serum glucose higher than $6 \mathrm{mmol} / \mathrm{l}$ at least measured on two occasions), and history of ischemic heart disease (myocardial infarction, angina pectoris). Presence of one of the following 
Table 3.1 Clinical features of the seven patients with an isolated monoparesis without signs of cortical dysfunction.

\begin{tabular}{|c|c|c|c|c|c|c|c|}
\hline \multirow[t]{2}{*}{ Clinical feature } & \multicolumn{6}{|c|}{ Patients } & \multirow[b]{2}{*}{7} \\
\hline & 1 & 2 & 3 & 4 & 5 & 6 & \\
\hline $\operatorname{sen}$ & $M$ & $\mathrm{M}$ & $F$ & $M$ & $\mathrm{~F}$ & $M$ & M \\
\hline Age (years) & 39 & 62 & 73 & 71 & 70 & 43 & 54 \\
\hline \multicolumn{8}{|l|}{ Monoparesis } \\
\hline face & - & - & * & - & - & - & - \\
\hline arm & + & * & - & + & - & + & + \\
\hline leg & 。 & 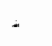 & + & - & + & - & - \\
\hline \multicolumn{8}{|l|}{$\mathrm{Cr} \operatorname{sen}$} \\
\hline nolesion & . & $\therefore$ & ${ }^{\prime}$ & - & - & + & . \\
\hline lacunar thfarct & - & . & . & - & . & . & - \\
\hline cortical infart & + & + & + & + & + & - & * \\
\hline \multicolumn{8}{|l|}{ Risk facters } \\
\hline hypertension & - & + & + & + & - & - & - \\
\hline diabetes mellitus & - & . & + & - & - & - & - \\
\hline \multicolumn{8}{|l|}{ history of Ischemic } \\
\hline heart disease & - & . & + & + & - & - & - \\
\hline Cardioembollc source & - & . & + & + & - & - & - \\
\hline \multicolumn{8}{|l|}{ Signiffcant $1 \mathrm{CA}$} \\
\hline stenosis & - & - & . & - & - & - & - \\
\hline \multicolumn{8}{|l|}{ Follow up } \\
\hline complete recovery & + & + & + & + & + & + & + \\
\hline
\end{tabular}

cardiac sources of embolism was determined: atrial fibrillation (chronic, paroxysmal), recent myocardial infarction (less than 6 weeks), prosthetic aortic or mitral valve, endocarditis, cardiomyopathy, mitral stenosis, left ventricular aneurysm, and intraventricular thrombus.

Axial CT scans were made with a Philips Tomoscan 350 or a Siemens Somatom Plus with consecutive slices of 9 or $10 \mathrm{~mm}$ thickness, parallel to the orbito-meatal line.

\section{Results}

From 1 July 1987 until 1 August 1989, 252 patients with a first-ever supratentorial brain infarct were registered. Seven patients $(3 \% ; 95 \%$ CI $1-5 \%)$ had isolated monoparesis. Table 3.1 shows the clinical features of these seven patients. Five patients had isolated brachial paresis and two patients had isolated crural paresis. Paresis involved the whole limb in four patients, only the proximal part in one, and only the distal part of the limb in two patients. Two patients had slight sensory disturbances. All patients had complete recovery within 2-4 weeks. Median time 


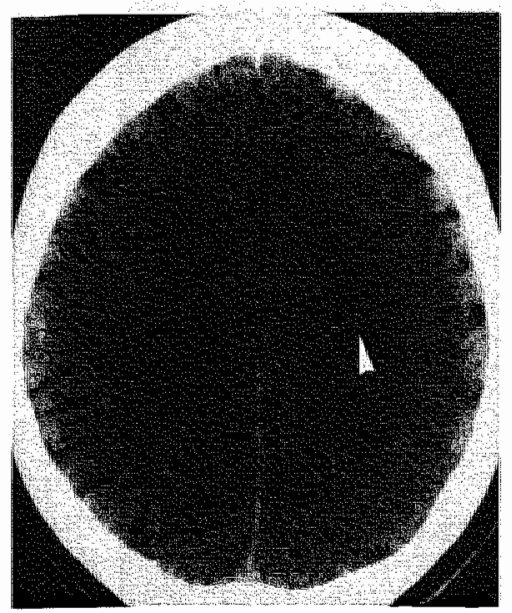

Figure 3.1 CT scan of patient 1 showing a small infarct with involvement of the cortex. and subcortex in the left hemisphere (arrow). This hemisphere also contained focal cortical atrophy.

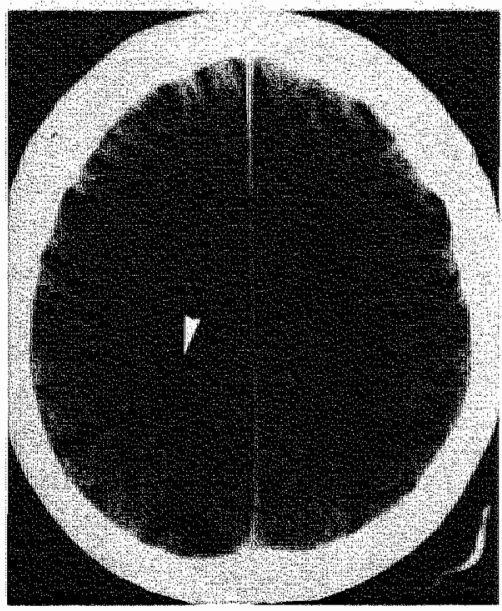

Figure 3.2 CT scan of patient 2 showing a small infarct with involvement of the cortex and subcortex in the right hemisphere (arrow).

between onset of symptoms and CT scanning was five days (range: 0 days- 4 weeks). CT showed an infarct involving the cortex and adjacent subcortex (Figs. 3.1-3.6) in six patients, whereas no lesion was seen in one. All infarcts were small, and were located in the territory of the middle cerebral artery. None of the patients had lacunar infarction on CT. Two patients had a potential cardioembolic source: one had nonrheumatic atrial fibrillation, and one had left ventricular aneurysm following myocardial infarction. None of the patients had significant stenosis of the ipsilateral internal carotid artery (ICA) (diameter reduction of more than $50 \%$ ).

\section{Discussion}

The corticospinal tract converges from a rather extensive sensorimotor cortex into a small tract running through the internal capsule to medullary pyramid and spinal cord. A small cortical infarct could therefore lead to monoparesis, whereas a lacunar infarct is more likely to cause more extensive neurological deficit, like faciobrachial, brachiocrural, or faciobrachiocrural weakness. On these anatomical grounds, Fisher 60,70 and Bamford et al. ${ }^{7}$ suggested that monoparesis should not be considered as a lacunar syndrome. Although others have found in single cases lacunar infarction on CT as the cause of monoparesis ${ }_{r}{ }^{52,109,138,172}$ this does not contradict the concept that the lesion underlying isolated monoparesis is usually localized in the cortex.

Bogousslavsky et al. ${ }^{24}$ studied clinical features in 380 patients with a middle cerebral artery pial territory infarct on CT selected from 1303 cases registered in the 


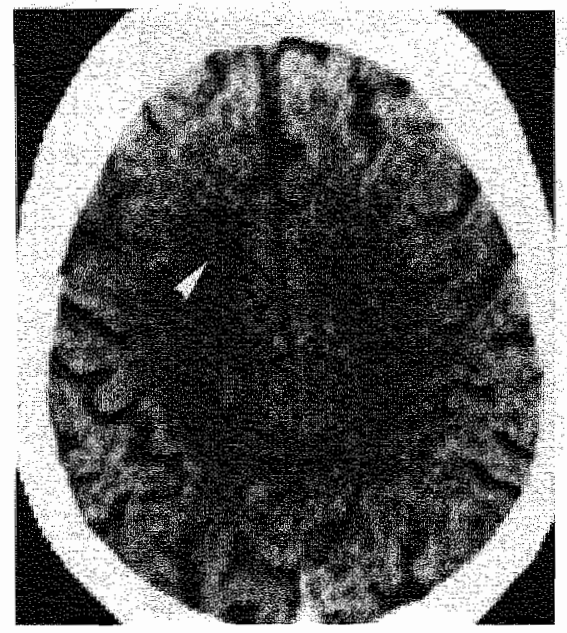

Figure 3.3 CT scan of patient 3 showing a small infarct involving the cortex in the right hemisphere (arrow).

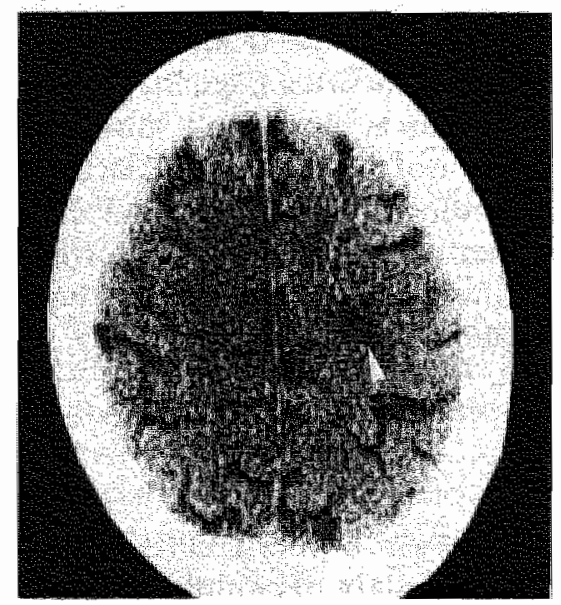

Figure 3.5 CT scan of patient 5 showing a small infarct involwing the cortex in the left hemisphere (arrow).

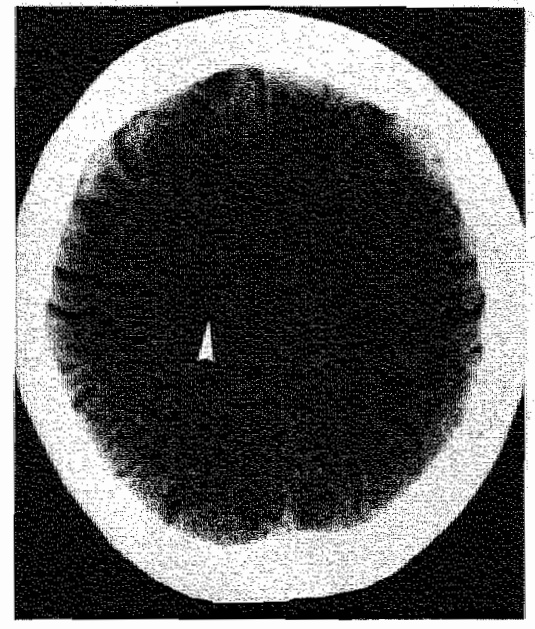

Figure $3.4 \mathrm{CT}^{*}$ scan of patient 4 showing a small infarct involving the cortex in the right hemisphere (arrow).

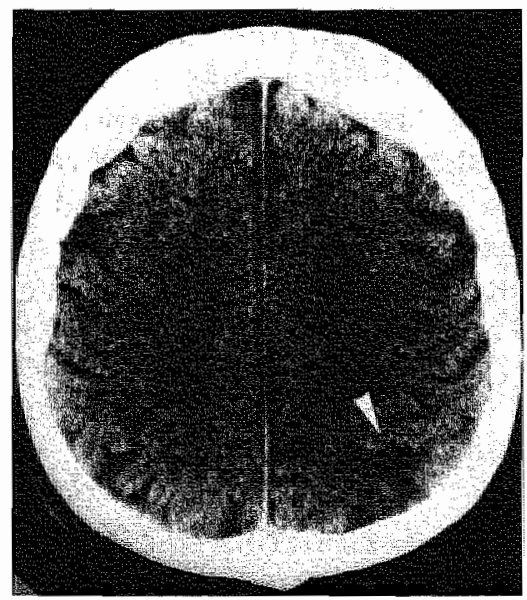

Figure 3.6 CT scan of patient 7 showing a small infarct involving the cortex in the left hemisphere (arrow).

Lausanne Stroke Registry, and found $52(14 \%)$ with monoparesis (either face or arm). However, this study, only containing patients with cortical infarction on CT, does not exclude lacunar infarction as a possible cause of monoparesis.

We prospectively studied the validity of clinical syndromes in all first-ever 
supratentorial brain infarcts, and found acute isolated monoparesis in seven of 252 consecutive patients $(3 \% ; 95 \%$ Cl $1-5 \%)$. All six patients with abnormal CT had an infarct involving the cortex and adjacent subcortex on $\mathrm{CT}$ compatible with the symptoms, whereas none of the patients had lacunar infarction caused by occlusion of one single, deep perforating artery. Although prior studies showed that occasionally monoparesis can result from a lacunar infarct, our study demonstrates that monoparesis following cerebral infarction is rare, and usually caused by a small infarct involving the cortex.

All cortical infarcts in our six patients had similar appearance on CT: they were small and located in middle cerebral artery territory. Some of these infarcts (Figs. 3. I3.3) could be interpreted as watershed infarcts, but none of the patients had experienced prior hypotension. The size of the infarcts indicates that they were caused by occlusion of a small cortical branch from the middle cerebral artery.

All our patients with monoparesis had a favourable prognosis with complete recovery within two to four weeks. Probably edema or the penumbra phenomenon might initially have been the major cause of the symptoms and signs.

Because the lacunar syndromes usually result from the occlusion of one, deep penetrator ${ }^{8,70}$ we conclude that isolated monoparesis is not a lacunar syndrome. 


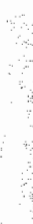




\section{Cardiac and carotid embolism are unlikely}

causes of lacunar infarction

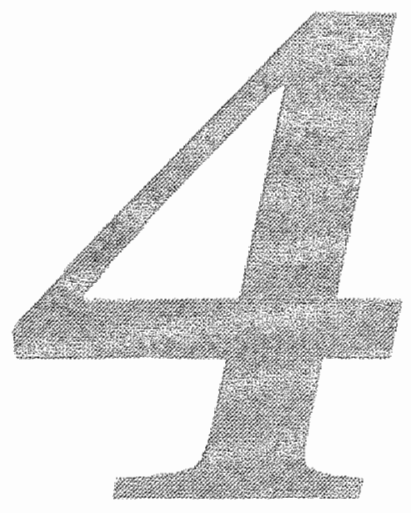





\section{Introduction}

Lacunar infarctions constitute an important subgroup $7,8,64,70,152,153$ representing between 13 and $25 \%$ of all cerebral infarcts. $7,23,89,129,151,174$ Recently we found that $41 \%$ of all prospectively registered patients with a first-ever supratentorial brain infarct had lacunar infarction (see Chapter 2). It is important to define their pathogenesis because they may warrant treatments different from infarcts involving the cerebral cortex. ${ }^{194,219}$

The lacunar hypothesis suggests that symptomatic lacunar infarcts usually present with specific lacunar syndromes, and that they are usually caused by a distinct vasculopathy of the small perforating arteries. ${ }^{8} \mathrm{~A}$ high positive predictive value ( $94 \%$ ) of the lacunar syndromes in diagnosing lacunar infarction was established in a prospective community-based study. ${ }^{7}$ We found positive and negative predictive values of 90 and $97 \%$, respectively (see Chapter 2 ), showing that the lacunar syndromes are indeed a good or even excellent clinical test to diagnose lacunar infarction.

The second part of the lacunar hypothesis is more difficult to investigate. There are few pathological studies because of the low early case fatality rate. ${ }^{64,69}$ Therefore, we have to turn to clinical studies to further elucidate the pathogenesis: establishing the frequency of potential cardiac and carotid sources of embolism would indirectly lead to more insight into the importance of small vessel disease underlying lacunar infarction. Some authors suggested the possibility of cardiac embolism in patients with lacunar infarction. ${ }^{169,189}$ However, in a recent community-based study, it was shown that lacunar infarcts are very unlikely caused by cardiac embolism. ${ }^{137}$ Some proposed that lacunar infarction may also be caused by artery-to-artery embolism from the carotid artery, ${ }^{80,161,169}$ thus arguing against the second part of the lacunar hypothesis. Others did not find carotid embolism as an usual cause of lacunar infarction. ${ }^{119,163,205}$ However, these studies on carotid embolism in lacunar infarction used selected groups of patients $s^{80,119,161,163,169}$ or criteria for patient-selection were not specified. ${ }^{205}$ Possible carotid embolism should be studied in a prospective series of all lacunar infarction patients without patient-selection.

Considering the hypothesis that lacunar infarction is usually caused by small vessel disease, the frequency of cardiac and carotid sources of embolism should be lower in patients with lacunar infarcts as compared to patients with cortical infarcts. The aim of the present study is to test this hypothesis by comparing the frequency of both cardiac and carotid sources of embolism, as well as the frequency of vascular risk factors, between a well-defined prospective series of patients with a first-ever lacunar and those with an infarct involving the cortex.

\section{Patients and methods}

The patients were registered between July 1987 and August 1989 in a prospective registry of all patients with a first-ever supratentorial brain infarct with symptoms lasting longer than 24 hours. 
Lacunar infarction was defined as a case of a lacunar syndrome in which $\mathrm{CT}$ findings were compatible with cerebral infarction due to occlusion of one single perforating artery, ${ }^{7}$ i.e. a subcortical, small, sharply marginated hypodense lesion with diameter smaller than $20 \mathrm{~mm}$, or if no specific lesion was visible on CT. All patients underwent CT examination. We distinguished four lacunar syndromes: pure motor stroke (PMS), sensorimotor stroke (SMS), pure sensory stroke (PSS) and ataxic hemiparesis $\left(\mathrm{AH}_{;}\right.$including dysarthria-clumsy hand cases) ${ }^{7,70}$ (see also Appendix).

Infarction involving the cortex was defined as a case of a cortical syndrome, i.e. a unilateral motor or sensory deficit, or both, in combination with signs of cortical dysfunction (e.g. aphasia, visual field deficit, visual spatial disturbances, apraxia, neglect or agnosia), in which $\mathrm{CT}$ findings or autopsy were compatible with infarction involving the cortex, or if no specific lesion was visible on $\mathrm{CT}$. Patients with large subcortical infarction were also included in this group, because pathogenesis is similar to infarction involving the corte ${ }^{16,134,189}$ (see also Chapter 7 ). Seven patients $(5 \%)$ had neither CT nor autopsy. Infarcts involving the cortex were divided into two groups by presumed cause: cardioembolic and atherothrombotic. Cardioembolic infarction was defined as an infarct involving the cortex in the presence of one of the following cardiac sources of embolism: atrial fibrillation (chronic, paroxysmal), recent myocardial infarction (less than 6 weeks), prosthetic aortic or mitral valve, endocarditis, cardiomyopathy, mitral stenosis, left ventricular aneurysm, and intraventricular thrombus. Atherothrombotic infarction was defined as an infarct involving the cortex, with no other apparent cause than large vessel disease, i.e. atherothrombosis or artery-to-artery embolism.

Routine investigations included standard blood and urine tests, electrocardiography, chest radiography, non-invasive carotid studies, and $\mathrm{CT}$. Non-invasive carotid studies consisted of multi-gate pulsed Doppler with spectral frequency analysis, Duplex scanning, or continuous-wave Doppler. Echocardiography, 24 hour-electrocardiographic (Holter) monitoring and cerebral angiography were performed in selected cases.

The following risk factors were recorded: hypertension (known hypertension treated with anti-hypertensive medication; two or more blood pressure-recordings of higher than $160 / 90 \mathrm{~mm} \mathrm{Hg}$ before stroke or at least one week after strokel, diabetes mellitus (known diabetes treated with diet and/or medication; fasting serum glucose higher than $6 \mathrm{mmol} / \mathrm{l}$ at least measured on two occasions), and history of ischemic heart disease (myocardial infarction, angina pectoris).

We compared the frequency of potential cardioembolic sources between the lacunar infarction group and cortical infarction group and the frequency of significant stenosis of the ipsilateral ICA (diameter reduction of more than 50\%) as a potential embolic source, between the lacunar infarction group and atherothrombotic infarction group (thus excluding the cardioembolic infarction group in the last comparison).

Differences between the two groups were analyzed using odds ratios with $95 \%$ $\mathrm{Cl}_{8}{ }^{76,157,188}$ and chi-squared test with Yates correction. 
Table 4.1 Frequency of potential cardioembolic sources in patients with lacunar and cortical infarction. An OR less than 1 indicates that the cardiac source of embolism is less frequent in the lacunar infarction group.

\begin{tabular}{lccccc}
\hline $\begin{array}{l}\text { Candiac sources } \\
\text { of embolism }\end{array}$ & $\begin{array}{l}\text { Lacumair } \\
\text { infarction } \\
\mathrm{n}=103(\%)\end{array}$ & $\begin{array}{l}\text { Cortical } \\
\text { infarction } \\
\mathrm{n}=144(\%)\end{array}$ & OR & $95 \% \mathrm{Cl}$ & $\mathbb{P}^{*}$ \\
\hline NRA.F & $10(10)$ & $43(30)$ & 0.25 & $0.12-0.53$ & $<0.001$ \\
Other & $5(5)$ & $7(5)$ & 1.00 & 0.31 .3 .24 & $\mathbb{N}$ \\
Total & $15(15)$ & $50(35)$ & 0.32 & $0.17-0.61$ & $<0.001$ \\
\hline
\end{tabular}

* chi-squared test with Yates correction

\section{Results}

From 1 July 1987 until 1 August 1989, 103 patients with a lacunar infarct and 144 patients with an infarct involving the cortex were registered. Among the patients with an infarct involving the cortex, 50 had cardioembolic and 94 atherothrombotic infarction. In the lacunar infarction group there were 57 males $(55.3 \%)$ and 46 females with a mean age of 67.2 (SD 10.3) years. In the cortical infarction group there were 78 males (54\%) and 66 females with a mean age of 71.2 (SD 12.4) years, while in the atherothrombotic infarction-group there were 59 males $(62.8 \%)$ and 35 females with a mean age of 69.7 (SD 13.0) years.

In the lacunar infarction group, angiography was performed in 17 patients $(17 \%)$. Non-invasive carotid studies were not performed in 17 patients $(17 \%)$ because they were too ill to cooperate adequately. Angiography was performed in 10 patients (11\%) of the atherothrombotic infarction group. Non-invasive carotid studies were not performed in 19 of these patients $(20 \%)$ for the same reasons as in the lacunar infarction group. Overall, $82 \%$ of all patients had non-invasive carotid study of which $86 \%$ had either multi-gate pulsed Doppler or Duplex scanning, and $14 \%$ continuouswave Doppler.

A cardiac source of embolism was significantly more common in the cortical infarction group (Table 4.1). The difference was caused by a statistically significant higher frequency of nonrheumatic atrial fibrillation (NRAF) in the cortical infarction group. The numbers of other cardiac sources were too small to allow conclusions on separate causes.

Ipsilateral ICA stenosis of more than $50 \%$ was significantly more frequent in patients with atherothrombotic cortical infarction compared with the lacunar stroke patients (Table 4.2). Stenosis of more than $50 \%$ of the contralateral ICA was found in 6 patients $(7.0 \%)$ with lacunar infarction, and in 10 patients $(13.3 \%)$ with atherothrombotic cortical infarction. Prevalence of remaining risk factors did not differ between patients with lacunar and atherothrombotic cortical infarction (Table 4.2). 
Table 4.2 Frequency of risk factors in patients with lacumar and atherothrombotic infarction.

\begin{tabular}{|c|c|c|c|c|c|}
\hline Pesk faictors & $\begin{array}{l}\text { Lacunar } \\
\text { infarction } \\
n=103(9)\end{array}$ & $\begin{array}{l}\text { Athero } \\
\text { thrombotic } \\
\text { infaretion } \\
\text { nom }=9 \%(\%)\end{array}$ & OR & $95 \% \mathrm{CI}$ & $\mathrm{p}^{\text {sili }}$ \\
\hline $\begin{array}{l}\text { Significant MCA } \\
\text { stenosis* }\end{array}$ & $11(13)$ & $28(37)$ & 0.35 & $0.16-0.76$ & $<0.001$ \\
\hline Hypertenslon & $51(50)$ & $35(37)$ & 1.65 & $0.94-2.91$ & NS \\
\hline Dlabetes mellitus & $28(27)$ & $25(27)$ & 1.03 & $0.55-1.93$ & NS \\
\hline $\begin{array}{l}\text { Hypertiension and } \\
\text { diabetes mellitus }\end{array}$ & $15(15)$ & $9(10)$ & 1.61 & $0.67-3.87$ & NS \\
\hline $\begin{array}{l}\text { History of ischemic } \\
\text { heart dilsease }\end{array}$ & $27(26)$ & $34(36)$ & 0.63 & $0.34-1.16$ & NS \\
\hline
\end{tabular}

- lacunar infarction $n=86$; atherothrombotic infarction $n=75$ (see text)

*t" chi-squared test with Yates correction

\section{Discussion}

Lacunar infarction is caused by occlusion of one single perforating artery, ${ }^{28,69,70} \mathrm{At}$ autopsy Fisher found in most cases small vessel vasculopathy, ${ }_{1}^{60-64,67-69,150}$ which he associated with hypertension. ${ }^{64}$ However, hypertension is the most important risk factor for all types of ischemic stroke, ${ }^{190,220}$ and many patients with lacunar infarction do not have hypertension. ${ }^{81,118}$ A problem is that hypertension has not been uniformly defined in the literature. Many studies used blood-pressure recordings shortly after stroke, which not always reliably reflect pre-stroke levels. ${ }^{192}$ However, pre-stroke measurements are not always available. In those cases, we used blood-pressure measurements at least one week after stroke, when blood-pressure has levelled off to pre-stroke values. ${ }^{3}$ Our data agree with those from the Oxfordshire Community Stroke Project, where no differences in hypertension between patients with lacunar infarction and carotid artery distribution infarction involving the cortex were found. ${ }^{137}$ Obviously, hypertension is an important but rather non-specific and not a unique risk factor in lacunar infarction. Diabetes mellitus can cause small vessel arteriolopathy, especially in the retina and kidney, and might therefore be an important risk factor for lacunar infarction. We, as others, ${ }^{1.77}$ did not find a difference in the frequency of diabetes mellitus between both groups. Weisberg reported, in preliminary data, that the combination of diabetes and hypertension is a major risk factor for lacunar infarction, ${ }^{219}$ but we could not confirm this.

The aim of our study was to test the hypothesis that lacunar infarction is usually caused by small vessel disease. Therefore, we expected the frequency of cardiac and carotid sources of embolism to be lower in patients with lacunar infarcts as compared to patients with infarcts involving the cortex. Embolism as a possible cause of lacunar 
infarction was assumed by Fisher in two of his cases, but an embolic source was not found. ${ }^{69}$ Some previous studies reported a potential cardioembolic source in up to $17 \%$ of patients with lacunar infarction. $80,85,151,164 ; 169,212$ Should a potential cardioembolic source in patients with lacunar infarction be considered as the cause of the infarct, or just as a coincidental finding? The frequency of the most prevalent potential cardioembolic source, viz. nonrheumatic atrial fibrillation, did not differ between patients with lacunar infarction and hospital control subjects. ${ }^{73}$ In a recent retrospective study, we found non-rheumathic atrial fibrillation to be approximately five times more frequent in patients with infarcts involving the cortex than in lacunar stroke patients, whereas the frequency did not differ between patients with lacunar stroke and primary intracerebral hemorrhage. ${ }^{14 \tau}$ In our present study, a potential cardiac source of embolism was approximately three times more frequent in the cortical infarct group than in the lacunar infarct group. Similar findings were also reported by others. ${ }^{137,138}$ This indicates that a potential cardioembolic source should generally be considered as a coincidental finding in patients with lacunar infarction; especially non-rheumatic atrial fibrillation is likely only a marker of generalized atherosclerosis in most cases. Considering that possible cardioembolic sources are only coincidental in patients with lacunar infarction, it is doubtful whether these patients should undergo extensive cardiac investigations or should be anticoagulated in the presence of one of these cardioembolic sources.

Could lacunar infarcts be caused by emboli from atherosclerotic carotid artery disease? Determining the frequency of carotid artery disease in patients with lacunar infarcts could indirectly offer insight into this problem. Kappelle et al. reviewed 11 retrospective studies in which the overall mean proportion of "operable ICA lesions" in patients with lacunar infarction was $22 \% .{ }^{119}$ However, most of these studies were retrospective and only a few selected patients underwent angiography, whereas definition of "operable ICA lesions" was unclear in most studies. $5,52,53,81,85,138,169,172,216,217,221$ In all prospective studies with angiography or carotid Doppler ultrasonography in patients with lacunar infarction, a minority of patients had carotid stenosis. ${ }^{80,119,163,205}$ However, most of these studies used selected groups of patients: only patients selected for angiography because they were found fit for carotid surgery, ${ }^{119}$ exclusion of lacunar patients with a potential cardioembolic source, ${ }^{119,163}$ or criteria for patient-selection were not specified. ${ }^{205}$ We aimed to study carotid disease in patients with lacunar infarction in general, and not only in those selected for angiography. Therefore, and in order not to be biased by using historical controls, we used non-invasive studies and compared the findings in a well-defined prospective and consecutive series of patients with lacunar infarction and patients with non-cardioembolic infarction involving the cortex. The fact that approximately $20 \%$ of our patients had not undergone non-invasive carotid studies unlikely led to a bias, because the number of patients without non-invasive carotid studies was similar in both groups, as were the reasons for not performing these tests. Doppler ultrasonography is a reliable technique for measuring carotid artery lesions. ${ }^{34}$ Small lesions might be missed but an increased incidence of stroke is particularly reported in severe carotid stenosis. ${ }^{34,162}$ We found that significant carotid stenosis was three times more prevalent in patients with infarction involving the cortex as compared to patients with lacunar infarction. 
These results support the view that carotid embolism is an unlikely cause of lacunar infarction. About $11 \%$ of neurologically asymptomatic patients have asymptomatic extracranial arterial disease, ${ }^{101}$ whereas angiography in healthy people sometimes showed carotid stenosis. ${ }^{55,98}$ Therefore, carotid lesions in patients with lacunar infarction most likelly are a coincidental marker of generalized a therosclerosis. The finding of $7 \%$ of our patients with lacunar infarction having a significant stenosis of the contralateral carotid artery is in line with this view. Therefore, we think that generally these patients should not undergo angiography and possibly carotid endarterectomy.

Our findings support the hypothesis that pathogenesis underlying lacunar infarction is different from that in infarcts involving the cortex. Potential cardiac and carotid sources of embolism are significantly less frequent in patients with lacunar infarction than in patients with infarction involving the cortex. Both these sources of embolism are probably only coincidental in patients with lacunar infarcts, supporting indirectly the hypothesis that a small vessel disease underlies lacunar infarctions. Analysis of other risk factors showed no differences between both groups. What determines whether (mainly) small or (mainly) large vessels, or both, will become affected in the presence of these risk factors remains unclarified. 


\section{Leuko-araiosis and lacunar infarcts usually result from small vessel disease}





\section{Introduction}

Periventricular diffuse white matter lucencies on $\mathrm{CT}$, so called leuko-araiosis ${ }_{i}{ }^{\text {"1 }}$ have been described in normal subjects, ${ }_{t}^{13,173,193}$ in patients with stroke ${ }^{22}$ or with vascular risk factors, and in various types of dementia. ${ }^{29,32,79,113,124,139,140,170,173,178,198}$ Autopsy studies related leuko-araiosis to small vessel disease. ${ }^{32,48,50,79,124,40,7078}$ Small vessel disease is also considered as the major cause of lacunar infarction. ${ }^{64,70}$ If lacunar infarction and leuko-araiosis are both caused by small vessel disease, leuko-araiosis would be more prevalent in patients with lacunar infarction than in patients with infarction involving the cortex.

The aim of this prospective clinical study was to test this hypothesis by comparing the frequency of leuko-araiosis between patients with a first-ever lacunar infarction and those with infarction involving the cortex. Furthermore, we have performed a risk factor analysis in patients with and without leuko-araiosis.

\section{Patients and methods}

The patients were registered between July 1987 and August 1989 in a prospective registry of all patients with a first-ever supratentorial brain infarct with symptoms lasting longer than 24 hours.

Lacunar infarction was defined as a case of a lacunar syndrome in which CT findings were compatible with cerebral infarction due to occlusion of one single perforating artery, ${ }^{7}$ i.e. a subcortical, small, sharply marginated hypodense lesion with diameter smaller than $20 \mathrm{~mm}$, or if no specific lesion was visible on CT. We distinguished four lacunar syndromes: pure motor stroke (PMS), sensorimotor stroke (SMS), pure sensory stroke (PSS) and ataxic hemiparesis (AH; including dysarthriaclumsy hand cases) ${ }^{7,70}$ (see also Appendix).

Infarction involving the cortex was defined as a case of a cortical syndrome, i.e. a unilateral motor or sensory deficit, or both, in combination with signs of cortical dysfunction (e.g. aphasia, visual field deficit, visual spatial disturbances, apraxia, neglect or àgnosia), in which CT findings or autopsy were compatible with infarction involving the cortex, or if no specific lesion was visible on $\mathrm{CT}$. Infarcts involving the cortex were divided into two groups by presumed cause: cardioembolic and atherothrombotic. Cardioembolic infarction was defined as an infarct involving the cortex in the presence of one of the following cardiac sources of embolism: atrial fibrillation (chronic, paroxysmal), recent myocardial infarction (less than 6 weeks), prosthetic aortic or mitral valve, endocarditis, cardiomyopathy, mitral stenosis, left ventricular aneurysm, and intraventricular thrombus. Atherothrombotic infarction was defined as an infarct involving the cortex with no other apparent cause than large vessel disease, i.e. atherothrombosis or artery-to-artery embolism.

Routine investigation included standard blood and urine tests, electrocardiography, chest radiography, non-invasive carotid studies, and $C T$. Non-invasive carotid studies consisted of multi-gate pulsed Doppler with spectral frequency analysis, Duplex scanning, or continuous-wave Doppler. Echocardiography, 24 hour-electrocardio- 


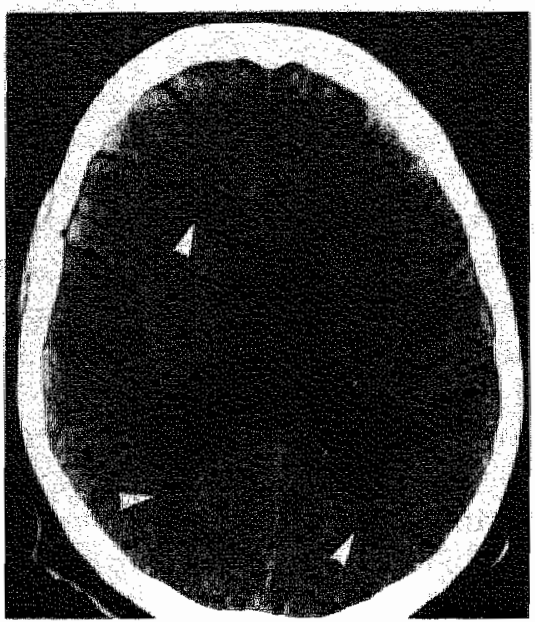

Figure $5.1 \mathrm{CT}$ scan of a 69 year old patient showing leuko-araiosis. Arrows point to the periventricular hypodensities in the white matter.

graphic (Holter) monitoring and cerebral angiography were performed in selected cases.

The following risk factors were recorded: hypertension (known hypertension treated with anti-hypertensive medication; two or more blood pressure-recordings of higher than $160 / 90 \mathrm{~mm} \mathrm{Hg}$ before stroke or at least one week after stroke), diabetes mellitus (known diabetes treated with diet and/or medication; fasting serum glucose higher than $6 \mathrm{mmol} / 1$ at least measured on two occasions), and history of ischemic heart disease (myocardial infarction, angina pectoris). We also determined the frequency of significant stenosis of the ICA (diameter reduction of more than 50\%).

Leuko-araiosis was defined as focal or diffuse hypodensities in the periventricular or deep white matter, without involving the cortex, and not compatible with infarction (Fig.5.1). We distinguished three grades of leuko-araiosis with increasing extensiveness:

Grade 1. Hypodensities around the frontal or occipital horns or both.

Grade 2. Hypodensities around frontal and occipital horns, and in region of cella media and centrum semiovale.

Grade 3. Extensive hypodensities in nearly the entire white matter.

Axial CT scans were made with a Philips Tomoscan 350 or a Siemens Somatom Plus with consecutive slices of 9 or $10 \mathrm{~mm}$ thickness, parallel to the orbito-meatal line. The $\mathrm{CT}$ scans were independently reviewed by two neurologists. Interobserver agreement for the assessment of leukomaraiosis on $\mathrm{CT}$ was determined and the results were analyzed using kappa-statistics. 1106

Dichotomous variables were analyzed using odds ratios with $95 \% \mathrm{Cl}, 76,157,188$ and chi-squared test with Yates correction. Two sample $t$ test was used for analysis of continuous variables (mean age). 
Table 5.1 Distribution of the three grades of leuko-araiosis (LA) among patients with lacunar and cortical infarction.

Cortical infarction

\begin{tabular}{|c|c|c|c|c|}
\hline \multirow[b]{2}{*}{ Grade of LA } & \multirow[b]{2}{*}{$\begin{array}{l}\text { Lacunar } \\
\text { infarction } \\
\mathrm{n}=30(9)\end{array}$} & & \multirow[b]{2}{*}{$\begin{array}{l}\text { Total } \\
\text { mas } 5(96)\end{array}$} \\
\hline & & $\begin{array}{l}\text { Atherothrombotic } \\
\text { infarction } \\
n=13 \text { (t) }\end{array}$ & $\begin{array}{l}\text { Culdulombolic } \\
\text { frufarction: } \\
n=11(0)\end{array}$ & \\
\hline Grade 1 & $16(54)$ & $9(69)$ & $7(64)$ & $32(58)$ \\
\hline Grade 2 & $10(33)$ & $4(31)$ & $4(36)$ & $14(33)$ \\
\hline Grade 3 & $4(13)$ & $0 \quad(0)$ & $0(0)$ & $4(9)$ \\
\hline
\end{tabular}

\section{Results}

From 1 July 1987 until 1 August 1989, 103 patients with a lacunar infarct and 144 patients with an infarct involving the cortex were registered. Among the patients with an infarct involving the cortex, 50 had cardioembolic and 94 atherothrombotic infarction.

In the patients with lacunar infarction, $3 \mathrm{CT}$ scans could not be reviewed reliably because of minor quality. In the patients with infarction involving the cortex, $16 \mathrm{CT}$ scans could not be reviewed because of either minor quality or because CT had not been performed ( 7 patients). Therefore, 100 patients with lacunar infarction and 128 patients with infarction involving the cortex ( 47 with cardioembolic and 81 with atherothrombotic infarction) entered the study. The two observers agreed in 220 of 234 reviewed $C T$ scans. Interobserver agreement was good, with corresponding kappa of 0.84 .

Of the 228 patients, fifty-four (24\%; $95 \% \mathrm{Cl} 19-30 \%)$ had leuko-araiosis. In the lacunar infarction group, 30 patients $(30 \% ; 95 \% \mathrm{Cl} 21-39 \%)$ had leuko-araiosis, and in the cortical infarction group 24 patients (19\%; 95\% CI 12-26\%). Among the cortical infarction group, 11 patients $(23 \% ; 95 \% \mathrm{Cl} 11-35 \%)$ with cardioembolic and $13(16 \%$; 95\% CI 8-24\%) with atherothrombotic infarction had leuko-araiosis.

Patients with lacunar infarction had significantly more often leuko-aralosis than patients with infarction involving the cortex (OR $1.82 ; 95 \% \mathrm{CI} 1.00-3.45 ; \mathrm{p}=0.05$ ). Leuko-araiosis was significantly more frequent in lacunar infarct patients than in atherothrombotic infarct patients (OR $2.24 ; 95 \% \mathrm{Cl} 1.08-4.65 ; \mathrm{p}<0.05$ ), whereas lacunar infarct patients had no more leuko-araiosis than cardioembolic infarct patients (OR $1.40 ; 95 \% \mathrm{CI} 0.63-3.13$ ). The frequency of leuko-araiosis did not differ significantly between cardioembolic and atherothrombotic cortical infarct patients (OR 1.60; 95\% CI 0.65-3.93).

Most patients (60\%) had grade 1 leuko-araiosis (Table 5.1). Grade 3 leuko-araiosis was only present in the lacunar infarction group. Risk factor-analysis is shown in Table 5.2. Overall, patients with leuko-araiosis were significantly older $(\mathrm{p}<0.001)$, and 
Table 5.2 Clinical features and frequency of risk factors in patients with and without leukoaratosis (LA). AnOR greater than 1 indicates that the risk factor is more prevalent in the group with LA.

\begin{tabular}{|c|c|c|c|c|c|}
\hline $\begin{array}{l}\text { Clinical features/ } \\
\text { risk factor }\end{array}$ & $\begin{array}{l}\text { LA present } \\
n=54(66)\end{array}$ & $\begin{array}{l}\text { LA absent } \\
n=174(4)\end{array}$ & OR & $95 \% \mathrm{CI}$ & $p^{*}$ \\
\hline Mean age & 74 & 67 & & & $<0.001$ \\
\hline Female & $32(58)$ & $75(43)$ & 1.92 & $1.03-3.57$ & $<0.05$ \\
\hline Hypertenstion & $26(48)$ & $77(44)$ & 1.17 & $0.64-2.15$ & NS \\
\hline Diabetes Mellitus & $11(20)$ & $49(28)$ & 0.65 & $0.31 \cdot 1.36$ & NS \\
\hline \multicolumn{6}{|l|}{ History of Ischernic } \\
\hline heart disease & $19(35)$ & $58(33)$ & 1.09 & $0.57-2.07$ & NS \\
\hline \multicolumn{6}{|l|}{$\begin{array}{l}\text { Significant ICA } \\
\text { stenosist }\end{array}$} \\
\hline unilateral & $6(15)$ & $30(21)$ & 0.56 & $0.25-1.72$ & NS \\
\hline bilateral & $3(8)$ & 7 (5) & 1.56 & $0.38-6.34$ & NS \\
\hline uni- or bilateral & $9(23)$ & $37(26)$ & 0.82 & $0.35-1.91$ & NS \\
\hline
\end{tabular}

- two sample t test (mean age) or chi-squared test with Yates correction

* LA present n=40; $L$ absent $n=142$

more were female ( $59 \%$; OR $1.92 ; 95 \% \mathrm{Cl} 1.03-3.57 ; \mathrm{p}<0.05)$. There were no significant differences in frequency of risk factors between patients with and without leuko-araiosis.

\section{Discussion}

The frequency of leuko-araiosis in consecutive CT series of all kinds of patients ranged from $0.1 \%$ to $8 \% .^{87,124,139,145,170,212}$ Leuko-araiosis was found in $24 \%(95 \% \mathrm{CI} 19-30 \%)$ of our patients with cerebral infarction, which confirms the prior suggested relationship of leinko-aralosis with stroke. ${ }^{111_{i} 113}$

Our analysis showed that leuko-araiosis is associated with increasing age and female sex, whereas the frequency of vascular risk factors did not differ between patients with and without leuko-araiosis. Other studies also demonstrated that the frequency of leuko-araiosis increases with age. ${ }^{79,104,124}$ We have no explanation for the fact that the leuko-araiosis group contained more females. Although most studies reported a high frequency of hypertension in patients with leuko-araiosis, $22_{,}, 32,87,104,123,124$ we did not find that hypertension was associated with leuko-araiosis in stroke patients. An explanation might be that hypertension as a risk factor for leuko-araiosis is not detected in a group of patients, like stroke patients, in whom hypertension is already highly prevalent.

Ouif finding that leuko-araiosis was significantly more frequent in patients with lacunar infarction than in those with infarction involving the cortex, particularly the 
patients suffering from atherothrombotic infarction, supports the hypothesis that leuko-araiosis like lacunar infarction is mainly caused by small vessel disease. Other authors also reported an association between leuko-araiosis and small vessel disease in stroke patients. ${ }^{104} \mathrm{In}$ previous reports, lacunar infarcts were seen on $\mathrm{CT}$ in patients with leuko-araiosis. ${ }^{22,111,113,123}$ Small vessel disease was found at autopsy by Fisher in patients with lacunar infarction. ${ }^{6,69}$ Autopsy in patients with leuko-araiosis showed a small vessel disease with hyalinization and segmental fibrinoid arterial degeneration of the small perforating arteries, lacunes, cystic lesions and demyelination. $32,50,79,87,124,140,178$ Small vessel disease probably leads to chronic ischemia in the arterial border zones between the diseased penetrating arteries and the small cortical vessels, resulting in demyelination and gliosis of this periventricular white matter, visible as leuko-araiosis on CT. Fazekas et al. found indeed a reduced white matter blood flow, measured with a Xenon-133 method, in patients with white matter lesions on MRI. ${ }^{56}$

The frequency of leuko-araiosis in our study did not differ between the patients with cardioembolic infarction and those with lacunar infarction. An explanation might be that these patients have chronic hemodynamic disorders caused by the cardiac disease, leading to hypoperfusion of the periventricular white matter. This last explanation is supported by the studies of De Reuck et al., who hypothesized that hypoperfusion of the periventricular arterial border zones can result from hemodynamic disorders, probably in an already compromised circulation in the territory of the deep perforating vessels. ${ }^{48-50}$

In conclusion, small vessel disease causing lacunar infarction might also lead to leuko-araiosis. Leuko-araiosis is associated with mental impairment and dementia. ${ }^{197}$ More studies on small vessel disease are therefore important because this could provide the possibility of prevention of multiple lacunar infarcts and dementia. 



\section{Two clinically distinct lacunar stroke entities}

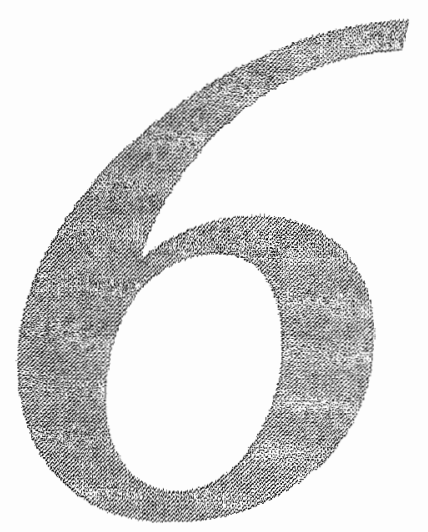





\section{Introduction}

Lacunar infarcts are small infarcts located deeply in the brain, or in the brainstem. ${ }^{\text {s }}$ They are caused by small vessel disease occluding a small perforating artery. ${ }^{6}, 69,70$ At autopsy, Fisher distinguished two types of small vessel disease: lipohyalinosis, mainly found in hypertensive patients with small, multiple, and ustually asymptomatic lacunes; , and microatheromatous disease, which mainly occurred in cases with larger, usually single symptomatic lacunes. ${ }^{64,69,70}$ Also related to small vessel lipohyalinosis. are periventricular white matter hypodensities visible on CT, so called leuko-araiosis, which are associated with mental impairment and dementia. ${ }^{32,50,79,87,91,197,212}$ Because lipohyalinosis is an important cause of both multiple lacunar infarcts and leukoaraiosis, ${ }^{32,50,64,69,87}$ it would be most important to distingulsh this wasculopathy from microatheromatous disease during life.

We hypothesize that if these two types of small vessel disease also manifest themselves separately during life, we should be able to recognize two lacunar stroke entities. We therefore investigated, in a prospective stroke registry using clinical and CT findings, whether lacunar stroke patients with one or more asymptomatic lacunar infarcts, and those with only one symptomatic lacunar infarction represent two distinct lacunar stroke entities, probably reflecting lipohyalinosis and microatheromatous disease, by comparing the frequency of vascular risk factors and leuko-araiosis between both these groups. Furthermore, if indeed two lacunar stroke entities can be distinguished, we determined whether location, involved vascular territory, and volume differed between the asymptomatic and symptomatic lacunar infarcts.

\section{Patients and methods}

The patients were registered between July 1987 and August 1989 in a prospective registry of all patients with a first-ever supratentorial brain infarct with symptoms lasting longer than 24 hours. All patients had an axial CT examination, which was made with a Philips Tomoscan 350 or a Siemens Somatom Plus with consecutive slices. of 9 or $10 \mathrm{~mm}$ thickness, parallel to the orbito-meatal line.

Symptomatic lacunar infarction was defined as a case of a lacunar syndrome in which CT findings were compatible with cerebral infarction due to occlusion of one single perforating artery, '1.e. a subcortical, small, sharply marginated hypodense lesion with diameter smaller than $20 \mathrm{~mm}$, or if no specific lesion was visible on $C T$.

In asymptomatic lacunar infarction, the lacunar infarct was not considered. compatible with the clinical signs and symptoms: that is, either at least one lacunar infarct in the contralateral (clinical asymptomatic) hemisphere, or at least two ipsilateral lacunar infarcts, or both.

The following risk factors were recorded: hypertension (known hypertension treated with anti-hypertensive medication; two or more blood pressure-recordings of higher than $160 / 90 \mathrm{~mm} \mathrm{Hg}$ before stroke or at least one week after stroke), diabetes mellitus (known treated diabetes; fasting serum glucose higher than $6 \mathrm{mmol} / \mathrm{l}$ at least measured at two occasions), and history of ischemic heart disease (myocardial 
Table 6.1 Clinical features, vascular risk factors, and leuko-araiosis in lacunar infarct patients with and without asymptomatic lacunar infarcts (AS LACI). An OR greater than 1 indicates that the risk factor is more frequent in the AS LACI group.

\begin{tabular}{|c|c|c|c|c|c|}
\hline $\begin{array}{l}\text { Cinalcal features/ } \\
\text { Risk factor }\end{array}$ & $\begin{array}{l}\text { Patients } \\
\text { with } \\
\text { AS LACl } \\
\mathbf{n}=21(96)\end{array}$ & $\begin{array}{l}\text { Patients } \\
\text { without } \\
\text { AS LACI } \\
n=79(\%)\end{array}$ & OR & $95 \% \mathrm{Cl}$ & $p^{*}$ \\
\hline Mean age (yi) & 69 & 67 & & & NS \\
\hline Men & $10(48)$ & $42(53)$ & 0.80 & $0.31-2.09$ & NS \\
\hline Hypertenision: & $15(72)$ & $34(43)$ & 3.31 & $1.16-9.43$ & $<0.05$ \\
\hline Dlabetes mellitus & $6(29)$ & $21(27)$ & 1.11 & $0.38-3.24$ & NS \\
\hline \multicolumn{6}{|l|}{ Htstory of lschemic } \\
\hline heart dlsease & $8(38)$ & $19(24)$ & 1.94 & $0.70-5.39$ & NS \\
\hline Leuko-aratosis & $15(72)$ & $15(19)$ & 10.67 & $3.81-32.10$ & $<0.001$ \\
\hline
\end{tabular}

- two sample t test (mean age) or chi-squared test with Yates correction

infarction, angina pectoris).

The lacunar infarcts were localized by means of an atlas comparing anatomic slices with standard CT slices. ${ }^{128}$ We distinguished the following locations: internal capsule (anterior limb (ICAL), posterior limb (ICPL)), corona radiata (CR), lentiform nucleus (LN), thalamus (Th), and caudate nucleus (CN).

We distinguished fourvascular territories using Damasio's brain templates ${ }^{43}:$ medial striate arteries (MSA), lateral striate or lenticulostriate arteries (LSA), anterior choroidal artery (ACA), and thalamoperforant arteries (TPA).

Infarct volume was estimated according to Nelson et al. ${ }^{161}$ : the length and width of the infarct was measured at right angles. The product was multiplied by thickness and number of affected slices, and divided by two.

Leuko-araiosis was defined as focal or diffuse hypodensities in the periventricular or deep white matter, without involving the cortex, and not compatible with infarction. ${ }^{198}$

CT scans were reviewed independently by two neurologists. The presence of lacunar infarcts, and of leuko-araiosis on CT was determined separately in two sessions. Interobserver agreement for the assessment of leuko-araiosis on CT was determined and the results were analyzed using kappa-statistics. ${ }^{186}$ In case of disagreement on the presence of an infarct or leuko-araiosis, CT was regarded as negative.

Dichotomous variables were analyzed by means of odds ratios (OR) with $95 \%$ $\mathrm{Cl}, 157,188$ and chi-squared test with Yates correction. Two sample $t$ test was used for analysis of continuous variables. 
Table 6.2 Location, involved vascular territory, and wolume of the asymptomatic (AS LACI) and symptomatic (S LACI) lacunar infarcts. For abbreviations, see text.

\begin{tabular}{|c|c|c|c|c|c|}
\hline Parameter & $\begin{array}{l}\mathrm{ASLACl} \\
\mathrm{m}=24(\%)\end{array}$ & $\begin{array}{l}\text { S LACL } \\
n=\$ 4(96)\end{array}$ & $\mathrm{OR}$ & $9586 \mathrm{cr}$ & $\mathrm{p}^{*}$ \\
\hline \multicolumn{6}{|l|}{ Location } \\
\hline$I C P L$ & $2(8)$ & $19(35)$ & 0.17 & $0.04-0.80$ & $<0.05$ \\
\hline $1 \mathrm{CAL} / \mathrm{CN}$ & $11(46)$ & $5(9)$ & 8.29 & $2.45-28.11$ & $<0,001$ \\
\hline $\mathbb{L N}$ & $2(8)$ & $6(11)$ & 0.73 & $0.17 \cdot 3.07$ & Ns \\
\hline $\mathrm{CR}$ & $8(33)$ & $22(41)$ & 0.73 & $0.27-2.00$ & NS \\
\hline Th & 1 (4) & $2(4)$ & 1.13 & $0.10-13.10$ & NS \\
\hline \multicolumn{6}{|c|}{ Vascularisation } \\
\hline MSA & $6(25)$ & $5 \quad(9)$ & 3.27 & $0.88-12.19$ & NS \\
\hline LSA & $12(50)$ & $11(20)$ & 3.91 & $1.38-11.05$ & $<0.025$ \\
\hline $\mathrm{ACA}$ & $5(21)$ & $36(67)$ & 0.13 & $0.04 \cdot 0.41$ & $<0,001$ \\
\hline TPA & 1 (4) & $2(4)$ & 1.13 & $0.10 \cdot 13.10$ & NS \\
\hline \multicolumn{6}{|l|}{ Volume } \\
\hline mean (ml) & 0.20 & 1.12 & & & $<0.001$ \\
\hline $95 \% \mathrm{Cl}$ & $0.12-0.28$ & $0.87-1.37$ & & & \\
\hline range & $0.02-0.81$ & $0.07 \cdot 3.69$ & & & \\
\hline
\end{tabular}

" two sample $t$ test (mean volume) or chi-squared test with Yates correction

\section{Results}

One hundred and three patients with lacunar infarction were registered. We excluded three patients because CT quality was insufficient. Interobserver agreement for the assessment of leuko-araiosis on CT was good with corresponding kappa of 0.84 .

Twenty-one patients (21\%; $95 \% \mathrm{CI} 13-29 \%)$ also had one or more asymptomatic lacunar infarcts, whereas 79 patients had only one symptomatic lacunar infarct. Mean age and male/female ratio did not differ between the patients with and without asymptomatic lacunar infarction (Table 6.1). Patients with asymptomatic lacunar infarction had significantly more often leuko-araiosis and hypertension. Prevalence of the remaining risk factors did not differ between both groups.

For further analysis of location, involved vascular territory, and volume of the symptomatic and asymptomatic lacunar infarcts, three patients who had two lacunar infarcts on the symptomatic side, were excluded because it was not known which of the two infarcts was the symptomatic one. In 54 of the remaining 97 patients, CT showed one symptomatic lacunar infarct (43 patients had no symptomatic infarct visible on $\mathrm{CT})_{t}$ and 24 asymptomatic lacunar infarcts in 21 patients. Locations of the 54 symptomatic lacunar infarcts differed from the 24 asymptomatic ones (Table 6.2): $19(35 \%)$ of the symptomatic infarcts were located in the posterior limb of internal capsule versus $2(8 \%)$ of the asymptomatic infarcts; $11(46 \%)$ of the asymptomatic 
infarcts were located in anterior limb of internal capsule and caudate nucleus versus $5(9 \%)$ of the symptomatic infarets. The frequency of the other involved locations did not differ between both groups. The frequency of the involved vascular territories in the symptomatic and asymptomatic lacunar infarcts did also differ (Table 6.2): anterior choroidal artery-territory was involved in almost $70 \%$ of the symptomatic infarcts, whereas the lateral and medial striate arteries were involved in $75 \%$ of the asymptomatic infarcts. Moreover, we found that the symptomatic lacunar infarcts were significantly larger than the asymptomatic lacunar infarcts (Table 6.2).

\section{Discussion}

The findings support our hypothesis that two distinct lacunar stroke entities can be broadly distinguished during life: lacunar stroke patients with the usual vascular risk factors and a single, symptomatic lacunar infarct without leuko-araiosis; and patients with multiple lacunar infarcts, a high frequency of hypertension and leuko-araiosis. Prior autopsy studies in a limited number of patients showed that leuko-araiosis and small, multiple, and usually asymptomatic lacunar infarcts were related to small vessel lipohyalinosis, whereas large, single, and usually symptomatic lacunar infarcts were caused by microatheromatous disease. $32,50,64,69,87$ Therefore, our two distinct lacunar stroke entities likely reflect indeed these two types of cerebral small vessel disease: patients with multiple lacunar infarcts and leuko-araiosis probably have lipohyalinosis, and those with a single, symptomatic lacunar infarct without leukoaraiosis probably have microatheromatous disease. Our finding that the asymptomatic lacunar infarcts were significantly smaller and differed from the symptomatic ones in location and involved vascular territory, further supports the notion that asymptomatic and symptomatic lacunar infarcts are caused by two different types of cerebral small vessel disease.

However, our hypothesis, which is based on clinical and radiological data, has to be confirmed in autopsy studies, but regarding the low early case fatality rate of lacunar stroke patients such studies will remain difficult to perform. Fisher found both types of small vessel disease at autopsy in one patient. ${ }^{64}$ This might also have been the case in some of our patients because the patients with asymptomatic lacunar infarcts also had one symptomatic lacunar infarct. Therefore, this group with presumed lipohyalinosis is probably mixed with some patients with presumed microatheromatous disease. Not every patient in the asymptomatic lacunar infarct group had hypertension or leuko-araiosis, which may indicate that some asymptomatic lacunes may be caused by microatheromatous disease.

The asymptomatic lacunar infarcts in our study were predominantly located in the frontal parts of the deep regions. These findings are in accordance with those of Ishii et $a l .{ }^{115}$ who found in 30 autopsy cases of vascular dementia with a lacunar state, diffuse softening of the white matter and multiple lacunes which were both found predominantly in the frontal lobes. This further supports the hypothesis that especially lipohyalinosis causes diffuse white matter softenings and multiple lacunar infarcts, with eventual development of subcortical vascular dementia, which may 
ultimately result in an extreme stage in so-called Binswanger's disease. Therefore, differentiating between the two lacunar stroke entities is important because this could provide the possibility of recognizing those patients who are at risk to develop eventually subcortical vascular dementia.

The role of hypertension as major risk factor for lacunar stroke has been questioned frequently. In clinical studies many lacunar infarct patients were not hypertensive, ${ }^{81,137}$ whereas the frequency and degree of hypertension did not differ between lacunar infarct patients and those with infarction involving the cortex. ${ }^{137}$ This could be explained by the fact that hypertension is a risk factor for all types of stroke, and by our finding that of all lacunar infarct patients only approximately $20 \%$ will suffer from presumed lipohyalinosis. Therefore, the higher blood pressure values of the lipohyalinosis patients are lost in those of the lacunar infarct group as a whole. The varying frequencies of hypertension between different lacunar stroke studies could be due to a varying degree by which patients with either type of small vessel disease have been included.

In conclusion, we hypothesize that two distinct types of cerebral small vessel disease can be distinguished during life. Of all lacunar stroke patients, approximately $80 \%$ presumably have microatheromatous disease and approximately $20 \%$ lipohyalinosis. Hypertension seems to be the major important risk factor for lipohyalinosis, diligent treatment of which may substantially reduce the risk of multiple neurological deficits, mental impairment, and eventual subcortical vascular dementia. 



\section{Large subcortical infarcts are not lacunar}

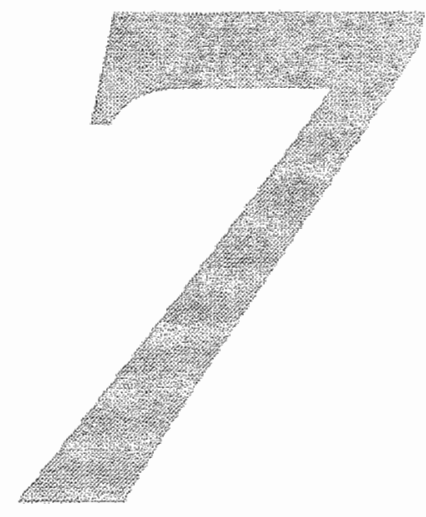





\section{Introduction}

Lacunar infarcts are small infarcts located in the deep parts of the brain, or in the brainstem. ${ }^{59}$ They usually present with specificlacunar syndromes, and usually result from small vessel disease occluding one small perforating artery. $78,64,69,70,153,483$ Signs of cortical dysfunction (e.g aphasia, visual field deficit, visual spatial disturbances, apraxia, neglect or agnosia) make a lacunar diagnosis very unlikely. ${ }^{700}$ It was shown that cardiac and carotid embolism are unlikely causes of lacunar infarction, supporting the hypothesis that lacunar infarcts are usually caused by small vessel disease (see also Chapter 4). ${ }^{19,137,163}$

In his studies on lacunar infarction, Fisher described so-called "giant" or "super" lacunes, "putamino-capsulo-caudate infarcts", or "capsular infarcts", $59,60,69$ also called "striatocapsular infarcts" by others. ${ }^{16}$ Some other studies on lacunar syndromes contained also such giant lacunes or putamino-capsular-caudate infarcts. ${ }^{172,216}$ The terminology has led to confusion; terms like "giant" or "super" lacunes suggest that these large subcortical infarcts have similar clinical presentation and pathogenesis as lacunar infarcts. However, in studies on large subcortical infarcts, most patients had signs of cortical dysfunction, potential cardioembolic source, significant carotid or middle cerebral artery stenosis or occlusion, features that argue against small vessel disease as the usual cause of these infarcts. ${ }^{1,16,134,189,215}$ Pathogenesis of these large subcortical infarcts could be clarified by comparing them with the other two pathophysiologically defined distinct cerebral infarct subgroups, lacunar and cortical infarcts. Insofar these large subcortical infarcts were studied, clinical presentation and presumed pathology were not compared with that of lacunar or cortical infarct patients, ${ }^{1,16,134,189,215}$ whereas these reports were small, ${ }^{1}$ or selected patients on the absence of known risk factors for a thrombotic disease, ${ }^{189}$ or used selection criteria that were not clearly defined. ${ }^{215}$

The aim of this study was to establish whether large subcortical infarcts resemble lacunar infarcts or infarcts involving the cortex, by comparing risk factor profile, frequency of potential cardiac sources of embolism and carotid occlusive disease, between patients with large subcortical infarcts and those with either lacunar infarction or infarction involving the cortex in a well-defined prospective series of patients with a first-ever brain infarct.

\section{Patients and methods}

The patients were registered between July 1987 and August 1989 in a prospective registry of all patients with a first-ever supratentorial brain infarct with symptoms lasting longer than 24 hours.

Lacunar infarction was defined as a case of a lacunar syndrome in which CT findings were compatible with cerebral infarction due to occlusion of one single perforating artery, ${ }^{7}$ i.e. a subcortical, small, sharply marginated hypodense lesion with diameter smaller than $20 \mathrm{~mm}$, or if no specific lesion was visible on CT. All patients had a CT examination. We distinguished four lacunar syndromes: pure 

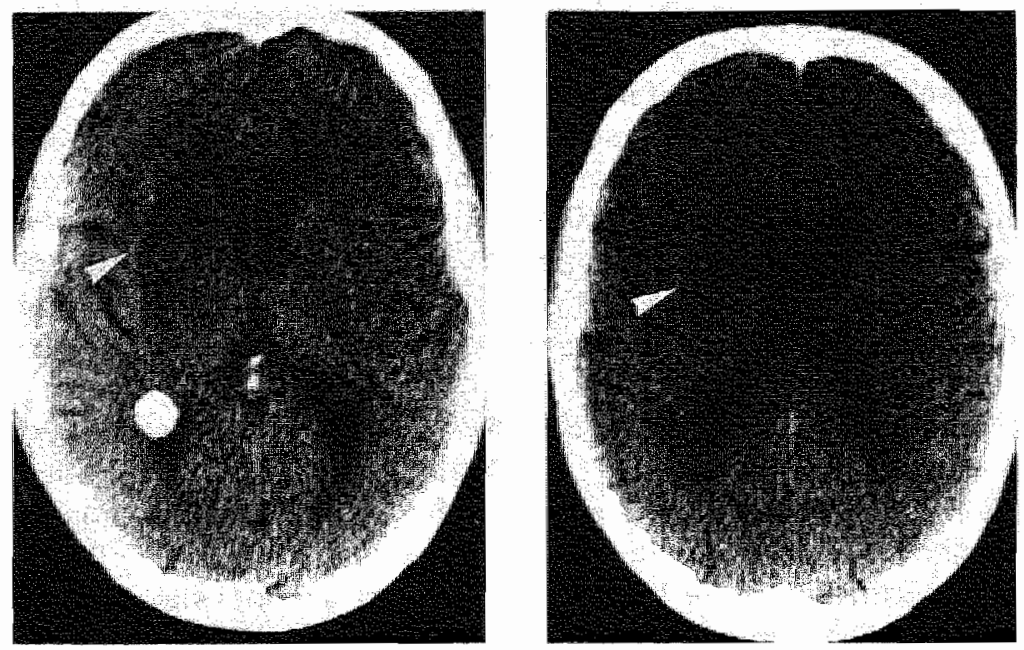

Figure $7.1 \mathrm{a}$ and $7.1 \mathrm{~b}$ CT scan (two slices) showing a large subcortical infarct in the right hemisphere (arrow). There is slight compression of the lateral ventricle due to edema.

motor stroke (PMS), sensorimotor stroke (SMS), pure sensory stroke (PSS) and ataxic hemiparesis ( $\mathrm{AH}$; including dysarthria-clumsy hand cases) ${ }^{7,70}$ (see also Appendix).

Infarction involving the cortex was defined as a case of a cortical syndrome, lie. a unilateral motor or sensory deficit, or both, in combination with signs of cortical dysfunction (e.g. aphasia, visual field deficit, visual spatial disturbances, apraxia, neglect or agnosia), in which CT findings or autopsy were compatible with infarction involving the cortex, or if no specific lesion was visible on CT. Seven patients ( $5 \%$ ) had neither CT nor autopsy.

Large subcortical infarcts were defined as large infarcts (maximum diameter at least $20 \mathrm{~mm}$ ) on $\mathrm{CT}$, not involving the cortex and not compatible with occlusion of one single perforating artery. All patients had CT.

The infarcts were localized using an atlas which compared anatomic slices with standard CT slices. ${ }^{128}$ The involved vascular territory was assessed using Damasio's brain templates, ${ }^{43}$ and the studies of Takahashi. ${ }^{201.202}$ Axial CT scans were made with a Philips Tomoscan 350 or a Siemens Somatom Plus with consecutive slices of 9 or 10 mm thickness, parallel to the orbito-meatal line.

The following risk factors were recorded: hypertension (known hypertension treated with anti-hypertensive medication; two or more blood pressure-recordings higher than $160 / 90 \mathrm{~mm} \mathrm{Hg}$ before stroke or at least one week after stroke), diabetes mellitus (known diabetes treated with diet and/or medication; fasting serum glucose greater than $6 \mathrm{mmol} / \mathrm{l}$ at least measured on two occasions), and history of ischemic heart disease (myocardial infarction, angina pectoris). Presence of one of the following cardiac sources of embolism was determined: atrial fibrillation (chronic, paroxysmal), recent myocardial infarction (less than 6 weeks), prosthetic aortic or mitral valve, endocarditis, cardiomyopathy, mitral stenosis, left ventricular aneurysm, and 

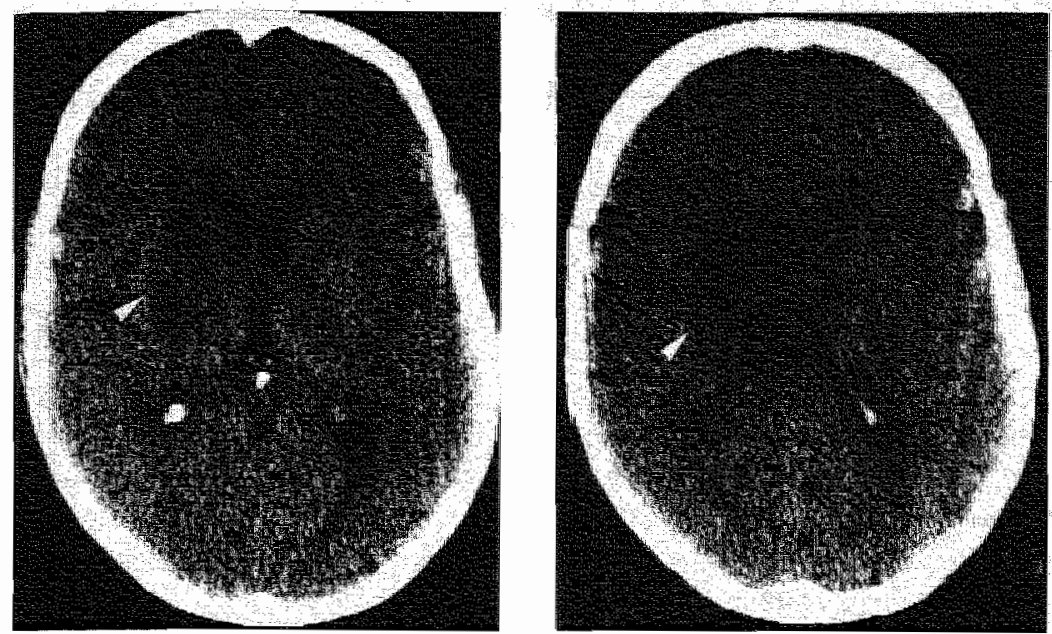

Figure $7.2 a$ and $7.2 b$ CT scan (two slices) showing a large subcortical infarct in the right hemisphere (arrow).

intraventricular thrombus. Significant carotid stenosis was assessed using noninvasive carotid studies ( $86 \%$ of patients had either multi-gate pulsed Doppler or Duplex scanning, and 14\% continuous-wave Doppler), or angiography.

Handicap was measured using the modified Rankin scale. ${ }^{171,206}$ Patients with Rankin grade 0,1 and 2 were considered independent; grade 3,4 and 5 were considered dependent. Hemiparesis was graded according to the MRC scale. ${ }^{146}$ Hemiparesis grade 4 was called mild; grade 0 to 3 was called severe.

We compared the frequency of vascular risk factors, potential cardioembolic sources, and the frequency of significant stenosis of the ICA (diameter reduction of more than $50 \%$ ) as a potential embolic source, between patients with large subcortical infarction, and those with lacunar infarction, or those with infarction involving the cortex.

Differences between the two groups were analyzed using odds ratios with $95 \%$ $\mathrm{Cl}_{1}{ }^{76,157,188}$ and chi-squared test with Yates correction.

\section{Results}

From 1 July 1987 until 1 August 1989, 252 patients with a first-ever supratentorial brain infarct were registered. Fifteen patients $(6 \% ; 95 \%$ CI $3-9 \%)$ had a large subcortical infarct, 103 patients ( $41 \% ; 95 \% \mathrm{Cl} 35-47 \%)$ had a lacunar infarct, and 129 patients $(51 \% ; 95 \% \mathrm{CI} 45-57 \%)$ had an infarct involving the cortex. In the subcortical infarct group there were 10 males (67\%) and 5 females, with a mean age of 69.2 (SD $8.5)$ years; in the lacunar infarction group there were 57 males ( $55.3 \%$ ) and 46 females with a mean age of 67.2 (SD 10.3) years, whereas the cortical infarct group contained 68 males (53\%) and 61 females with a mean age of 71 (SD 12.7) years. 
Table 7.1 Clinical features of the 15 patients with a large subcortical infarct (percentage between brackets).

\begin{tabular}{|c|c|c|}
\hline Clnilcal feature & Num & attents \\
\hline \multicolumn{3}{|l|}{ sex } \\
\hline male & 10 & $(67)$ \\
\hline female & 5 & (33) \\
\hline Mean age (years) & 692 & $(S D 8.5)$ \\
\hline \multicolumn{3}{|l|}{ Consciousness } \\
\hline normal & 11 & (73) \\
\hline slightly depressed (translent) & 4 & $(27)$ \\
\hline Lacunar syndrome & 3 & (20, $2 \mathrm{SMS}, 1 \mathrm{PMS})$ \\
\hline Cortical dysfunction & 12 & (80) \\
\hline dysphasia & 7 & $(48)$ \\
\hline visual field deficit & 7 & $(47)$ \\
\hline contralateral neglect & 4 & (27) \\
\hline Hemiparesis & 14 & (93) \\
\hline milld & 4 & $(27)$ \\
\hline severe & 10 & (67) \\
\hline Hemisensory deficits & 10 & (67) \\
\hline \multicolumn{3}{|l|}{ Handicap on admission } \\
\hline ADL-independent & 1 & $(7)$ \\
\hline ADL-dependent & 14 & (93) \\
\hline
\end{tabular}

Angiography was performed in 1 patient of the large subcortical infarction group, in 9 patients of the cortical infarction group, and in 17 patients of the lacunar infarction group. Non-invasive carotid studies were not performed in $17 \%$ of patients with lacunar infarction, and in $34 \%$ of patients with cortical infarction, because they were too ill to cooperate adequately.

The subcortical infarcts had characteristic size and shape on $C T$, which distinguished them easily from lacunar infarcts (Figs. 7.1 and 7.2). The infarct was visible on at least two CT slices. They were typically comma-shaped or lens-shaped, and involved usually the head of the caudate nucleus, the anterior limb of the internal capsule, the lentiform nucleus and corona radiata. In 10 patients, the posterior limb of the internal capsule was also involved. CT showed also compression of the lateral ventricle due to edema in 5 patients (Fig.7.1). The infarcts were located in the territory of the lenticulostriate (lateral striate) arteries. Medial striate arteries including recurrent artery of Heubner or anterior choroidal artery were also involved in 6 and 7 patients, respectively.

Table 7.1 shows the clinical features of the 15 patients with a subcortical infarct; 3 patients (20\%) presented with a lacunar syndrome (2 SMS and 1 PMS). The other 12 patients had signs of cortical dysfunction: 7 patients had dysphasia, 7 had visual 
Table 7.2 Frequency of vascular risk factors, significant carotid stemosis, and potential cardioembolic sources in large subcortical and lacunar infarcts. An OR greater than 1 indicates that the risk factor is more frequent in large subcortical infarction.

\begin{tabular}{|c|c|c|c|c|c|}
\hline Fusk factor & $\begin{array}{l}\text { Large } \\
\text { subcortical } \\
\text { infarction } \\
\mathrm{n}=15(\%)\end{array}$ & $\begin{array}{l}\text { Lacunar } \\
\text { infarction } \\
\mathrm{n}=103(\%)\end{array}$ & OR & $95 \% \mathrm{CI}$ & $\mathrm{p}^{*}$ \\
\hline Hypertension & $8(53)$ & $51(50)$ & 1.17 & $0.40-3.44$ & NS \\
\hline Diabetes mellitus & $2(13)$ & $28(27)$ & 0.41 & $0.09 \cdot 1.93$ & NS \\
\hline $\begin{array}{l}\text { History of ischemic } \\
\text { heart disease }\end{array}$ & $8(53)$ & $27(26)$ & 3.22 & $1.07-9.65$ & $<0.05$ \\
\hline $\begin{array}{l}\text { Significant ICA } \\
\text { stenosis }\end{array}$ & $4(27)$ & $11(13)$ & 2.48 & $0.67-9.22$ & NS \\
\hline $\begin{array}{l}\text { Cardiac source of } \\
\text { embolism }\end{array}$ & $7(47)$ & $15(15)$ & 5.13 & $1.61-16.31$ & $<0,01$ \\
\hline
\end{tabular}

* chi-squared test with Yates correction

* lacunar infarction $n=86$

Table 7.3 Frequency of vascular risk factors, significant carotid stenosis, and potential cardioembolic sources in large subcortical infarction and infarction involving the cortex.

\begin{tabular}{llllll}
\hline Risk factor & $\begin{array}{l}\text { Large } \\
\text { subcortical } \\
\text { Infarction } \\
\mathrm{n}=15(\%)\end{array}$ & $\begin{array}{l}\text { Infarction } \\
\text { involving } \\
\text { the cortex } \\
\mathrm{n}=129(\%)\end{array}$ & OR & $95 \% \mathrm{Cl}$ & $\mathrm{p}^{*}$ \\
\hline $\begin{array}{l}\text { Hypertension } \\
\text { Diabetes mellitus }\end{array}$ & $8(53)$ & $49(318)$ & 1.87 & $0.64-5.50$ & NS \\
$\begin{array}{l}\text { History of ischemic } \\
\text { heart disease }\end{array}$ & $2(13)$ & $38(29)$ & 0.37 & $0.08-1.71$ & NS \\
$\begin{array}{l}\text { Significant ICA } \\
\text { stenosis }\end{array}$ & $8(53)$ & $48(37)$ & 1.93 & $0.66-5.67$ & NS \\
$\begin{array}{l}\text { Cardiac source of } \\
\text { embolism }\end{array}$ & $4(27)$ & $26(31)$ & 0.83 & $0.24-2.85$ & NS \\
\hline
\end{tabular}

- chi-squared test with Yates correction

infarction involving the cortex $n=85$ 
field deficit and 4 patients exhibited contralateral neglect. Ten patients had severe hemiparesis, and were ADL-dependent, and only 1 patient was ADL-independent on admission. Ten patients had hemisensory deficits. Transient, slightly depressed consciousness was found in 4 patients.

A history of ischemic heart disease was more frequent in the subcortical infarction group (Table 7.2). Prevalence of the other two vascular risk factors did not differ between patients with subcortical and lacunar infarction. Significant carotid stenosis was twice more frequent in the patients with subcortical infarction, but the difference was not statistically significant. Almost half of the patients with a subcortical infarct had a potential cardioembolic source, which was significantly higher than in the patients with a lacunar infarct. Vascular risk factors, significant carotid stenosis, and potential cardioembolic sources did not differ between patients with subcortical and cortical infarction (Table 7.3).

\section{Discussion}

Of all our registered patients with a first-ever supratentorial brain infarct, $6 \%(95 \% \mathrm{CI}$ $3-9 \%$ ) had a large subcortical infarct. This is more frequent than in the two other prospective series, where $1 \%$ of all registered stroke patients had such infarcts. ${ }^{16,134}$ However, in these studies besides all patients with stroke, those with TIA ${ }^{16}$ were also registered.

Patients with lacunar infarction have no signs of cortical dysfunction, although rarely they may have dysphasia or neglect. ${ }^{57,70,203,209}$ Eighty percent of our patients with large subcortical infarction had dysphasia, visual field deficit and/or contralateral neglect. Other authors also described dysphasia ${ }^{1,16,42,134,160,165,189,215}$ and neglect $16,58,96,134,189,196,215$ in such patients. Rarely, these patients present with dystonia ${ }^{46}$ or ballism. ${ }^{136}$ Signs of cortical dysfunction (dysphasia, neglect, visual field deficit) can be caused by interruption of the subcortical arcuate fibers, or by dysfunction of the cerebral cortex itself caused by low regional cerebral blood flow areas in the cortex overlying the deep lesions, being sufficient for tissue viability, but insufficient for normal tissue function. ${ }^{165,215}$ Most of our patients had severe neurological deficit; only one $(7 \%)$ was ADL-independent on admission, compared with $31 \%$ of lacunar infarction patients, and $16 \%$ of cortical infarction patients (Chapter 2). Obviously, clinical features and the degree of initial neurological deficit in patients with subcortical infarction differ from those found in patients with lacunar infarction, but resemble those in pattents with infarction involving the cortex.

Do large subcortical infarcts resemble lacunar infarcts with regard to pathogenesis? Like others, ${ }^{1,16}$ we found that the large subcortical infarcts were located in the territory of the lenticulostriate arteries, but in some of our patients medial striate arteries including the recurrent artery of Heubner, or the anterior choroidal artery, or both, were also involved. However, the fact that the infarcts were confined to the territory of the small penetrating arteries does in itself not prove that they resulted primarily from small vessel disease. It is highly unlikely that several separate penetrators occlude at the same time. It is therefore more likely that the subcortical 
infarct results from occlusion of a large, common feeding artery due to local atherothrombosis, or cardiac or carotid embolism. Large subcortical infarcts have been described in angiographically prowen occlusion or severe stenosis of the middle cerebral artery ${ }^{1,5,33,175}$ or internal carotid artery. ${ }^{16,19,134}$ We found severe occlusive carotid disease to be twice more frequent in subcortical infarcts than in lacunar infarcts. Due to the small number of patients in the subcortical infarct group, the difference did not reach the level of statistical significance. Cardiac embolism may cause subcortical infarction by occluding the middle cerebral or internal carotid artery. ${ }^{33,189}$ Most of our patients with large subcortical infarction had a potential cardiac or large vessel embolic source. One patient with atrial fibrillation developed subcortical infarction a few hours following cardiac conversion. Thus, large subcortical infarction results from interruption of blood flow to the area supplied by the deep penetrators due to local occlusive disease, or embolism obstructing the common feeding artery at the orifices of several small perforating arteries (lenticulostriate, anterior choroidal and/ or medial striate arteries), ${ }^{35}$ whereas the cortical territories are spared by collateral circulation, which is absent in the deep territories. Obviously, the pathogenesis of subcortical infarction differs from that of lacunar infarction, whereas it resembles that of infarcts involving the cortex. Therefore, therapy in patients with large subcortical infarction should be similar to that in patients with infarcts involving the cortex: depending on the type of cardioembolic source if present, they should be considered for anticoagulation, and they should also be included in the ongoing trials on the value of carotid surgery.

The terminology of these infarcts in the literature is confusing. We object to terms like "capsular", "striatocapsular", or "putamino-capsulo-caudate" infarcts, because the infarcts are not always confined to these structures, but often extend into the corona radiata. Terms like "giant lacune", and "super lacune" incorrectly suggest small vessel disease as usual underlying vascular cause as it is in lacunar infarcts. However, our data and those from others indicate the opposite: subcortical infarcts are usually caused by cardioembolism or large vessel disease. Moreover, their presenting signs and symptoms resemble that of infarcts involving the cortex rather than lacunar infarcts. Therefore, we suggest these lesions to be called "large subcortical infarcts". 

The course of corticospinal, thalamocortical, and cerebellar pathways in man inferred from lacunar infarct patients 


\section{Introduction}

Lacunar infarcts are small infarcts located deeply in the brain. Many case reports and some larger studies ${ }^{52,110,161,169,172,216,217}$ have described $\mathrm{CT}$ findings in patients with lacunar infarcts, but most of these studies did not relate clinical symptoms to infarct locallization. Lacunar infarcts could be considered as "experiments of nature": small lesions confined to certain structures in the brain presenting with well defined clinical syndromes, enabling to study functional anatomy of central motor, sensory, and cerebellar pathways in living humans. Correlating the location of the small infarct with the clinical syndrome can yield important information about the precise course of these different pathways.

The aim of our study is, therefore, to report on the detailed CT findings in a large well-defined prospective series of patients presenting with lacunar infarction, allowing determination of the precise course of the corticospinal, thalamocortical and cerebellarcortical or corticocerebellar pathways at the level of internal capsule and corona radiata, by correlating the infarct localization with the clinical symptoms.

\section{Patients and methods}

The patients were registered between July 1987 and August 1989 in a prospective registry of all patients with a first-ever supratentorial brain infarct with symptoms lasting longer than 24 hours.

Lacunar infarction was defined as a case of a lacunar syndrome in which CT findings were compatible with cerebral infarction due to occlusion of one single perforating artery, ${ }^{7}$ i.e. a subcortical, small, sharply marginated hypodense lesion with diameter smaller than $20 \mathrm{~mm}$, or if no specific lesion was visible on CT. All patients had CT examination. We distinguished four lacunar syndromes: pure motor stroke (PMS), sensorimotor stroke (SMS), pure sensory stroke (PSS) and ataxic hemiparesis ( $\mathrm{AH}$; including dysarthria-clumsy hand cases) ${ }^{7,70}$ (see also Appendix).

Distribution of motor deficit (faciobrachial, brachiocrural or faciobrachiocrural) and presence of dysarthria (not attributable to eventual facial paresis) were recorded in patients with PMS and SMS.

The lacunar infarcts were localized using an atlas comparing anatomic slices with standard CT slices. ${ }^{128}$ We distinguished the following locations (Fig.8.1): internal capsule (genu, anterior limb (ICAL), posterior limb (ICPL)), corona radiata (CR), lentiform nucleus (LN), thalamus (Th), and caudate nucleus (CN). The posterior limb of the internal capsule was divided into three parts (anterior part (ICPL-AP), medial part (ICPL-MP) and posterior part (ICPL-PP)). Corona radiata was divided into an anterior (CRA) and posterior (CRP) part. Overlap between locations was also noted.

The involved vascular territory was assessed using Damasio's brain templates ${ }^{43}$ For terminology, we also used the studies of Takahashi. ${ }^{201,202}$ We distinguished four vascular territories:

I. Medial striate arteries (MSA) with recurrent artery of Heubner from anterior cerebral artery. 
Table 8.1 CT findings in the 50 patients with a lacunar syndrome and a compatible lacumar infarct (percentage between brackets).

\begin{tabular}{lllll}
\hline & PMS & SMS & AH & PSS \\
\hline Number of inifarcts & $18(36)$ & $18(36)$ & $13(26)$ & $1(2)$ \\
Mean wollume (inl) & 1.32 & 0.93 & 0.91 & $0.09 *$ \\
$(95 \%$ Cl) & $0.84-1.80$ & $0.56-1.30$ & $0.48-1.38$ & - \\
Range of volumes & $0.07-3.69$ & $0.07-2.92$ & $0.28-2.45$ & - \\
\hline
\end{tabular}

- volume of one infarct

II. Lateral striate or lenticulostriate arteries (LSA) from middle cerebral artery.

III. Anterior choroidall artery (ACA) and additional small branches from internal carotid artery.

IV. Thalamotuberal, thalamoperforate, thalamogeniculate and posterior choroidal arteries (TPA) from posterior cerebral artery.

Infarct volume was estimated according to Nelson et al. ${ }^{161}$ : the lenght and width of the infarct was measured at right angles. The product was multiplied by thickness and number of affected slices, and divided by two.

CT scans were independently reviewed by two neurologists without knowledge of the clinical syndrome. In case of disagreement on the presence of an infarct, CT was regarded as negative. Axial CT scans were made with a Philips Tomoscan 350 or a Siemens Somatom Plus with consecutive slices of 9 or $10 \mathrm{~mm}$ thickness, parallel to the orbito-meatal line.

\section{Results}

From 1 July 1987 until 1 August 1989, 98 patients with lacunar infarction were registered. There were 55 men ( $56 \%$ ) and 43 women with a mean age of 67.2 (SD 10.3) years. Fifty-seven patients had compatible lacunar infarction on CT $(58 \% ; 95 \%$ CI 48$68 \%$ ). Two positive CT scans could not be analyzed in detail because of insufficient quality. Three patients, who had two lacunar infarcts on the symptomatic side, were excluded from further analysis because it was not known which of the two infarcts was the symptomatic one. For further analysis of supratentorial location and involved vascular territory, two patients with lacunar infarction in the pons were excluded. Therefore, 50 patients with a compatible lacunar infarct on CT entered the study. Fourteen patients had an asymptomatic lacunarinfarct in the contralateral hemisphere. Table 8.1 shows the CT findings of these 50 patients. Infarct volume did not differ between the different lacunar syndromes. Volumes ranged from 0.07 to $3.69 \mathrm{ml}$. All infarcts but one were smaller than $3 \mathrm{ml}$. The $50 \mathrm{infarcts}$ were located as follows (Table 8.2; Fig. 8.1): internal capsule: 21 ( $42 \%)$, corona radiata: 22 (44\%), lentiform nucleus: $4(8 \%)$, thallamus: $2(4 \%)$, and caudate nucleus: $1(2 \%)$. The involved vascular 
Table 8.2 Locations of the infarcts in the patients with a lacunar syndromeand a compatible lacunar infarct. See text for abbreviations.

\begin{tabular}{|c|c|c|c|c|c|}
\hline Location & PMS & SMS & $\mathrm{AH}$ & pSS & Total \\
\hline ICAL & - & - & - & . & $=$ \\
\hline ICALCN & 2 & 1 & $=$ & - & 3 \\
\hline ICPL & 3 & 3 & 2 & . & 8 \\
\hline ICPL-Th & - & 2 & 1 & - & 3 \\
\hline ICPL-LN & - & 1 & 1 & . & 2 \\
\hline ICPL-CR & 3 & 1 & 1 & - & $s$ \\
\hline $\mathrm{CRA}$ & . & 3 & 1 & . & 4 \\
\hline $\mathrm{CRP}$ & 6 & 6 & 3 & - & 15 \\
\hline CR-LN & 3 & - & - & . & 3 \\
\hline $\mathrm{CN}$ & 1 & - & . & . & 1 \\
\hline $\mathrm{LN}$ & $\cdot$ & 1 & 3 & $=$ & 4 \\
\hline Th & . & - & 1 & 1 & 2 \\
\hline
\end{tabular}
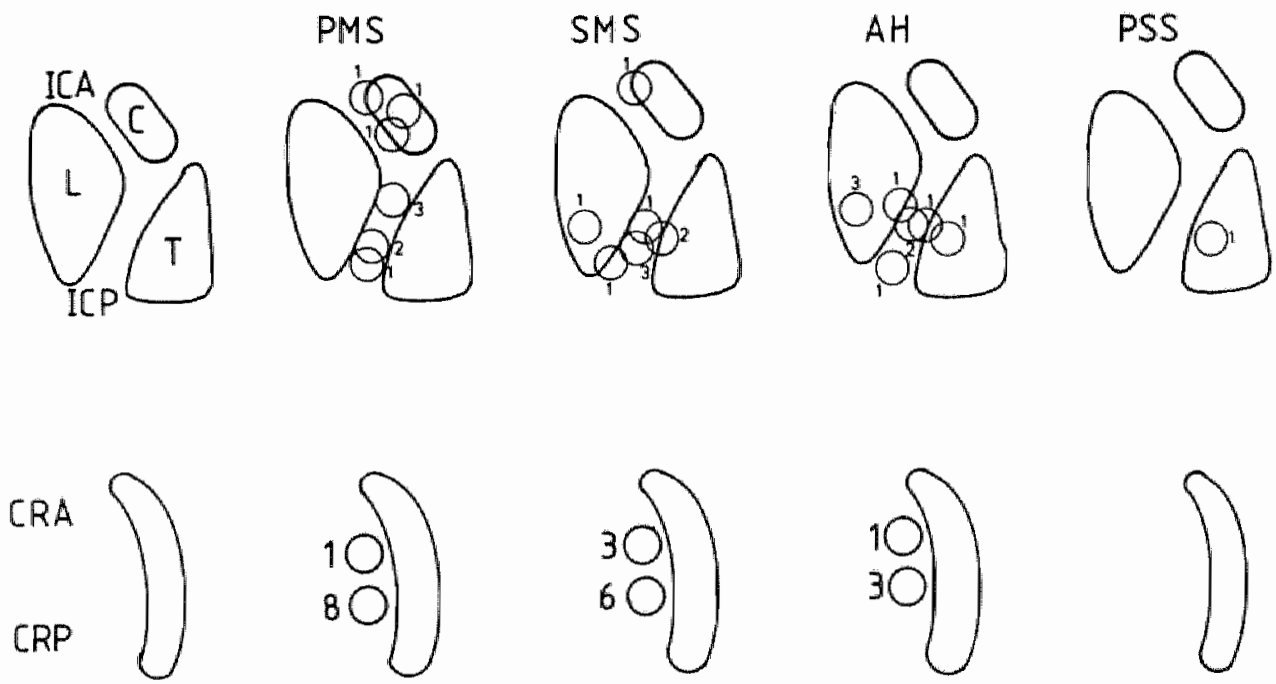

Figure 8.1 Locations of the infarcts in the patients with a lacunar syndrome and a symptomatic lacunar infarct. The upper part of the figure reflects the level of the internal capsule and the lower part of the figure the level of the corona radiata. The number of patients is given at every location. See text for abbreviations.

territories were (Table 8.3): anterior choroidal artery-territory: $34(68 \%)$, lenticulostriateterritory: $10(20 \%)$, and the other territories: $6(12 \%)$. The frequency in which different vascular territories were involved did not differ between PMS, SMS and AH. 
Table 8.3 The involved vascular territories in the 50 patients with a lacunar syndrome and a compatible lacunar infarct. See text for abbreviations.

\begin{tabular}{lrrrrr}
\hline $\begin{array}{l}\text { Vascular } \\
\text { territory }\end{array}$ & PMS & SMS & AH & PSS & Total \\
\hline MSA & 3 & 1 & - &. & 4 \\
WA & 3 & 4 & 3 & - & 10 \\
ACA & 12 & 13 & 9 & - & 34 \\
TPA & - & - & 1 & 1 & 2 \\
\hline
\end{tabular}

Table 8.4 Correlation between infarct localization and type of motor deficit and dysarthria in patients with PMS and SMS. See text for abbreviations.

\begin{tabular}{lllll}
\hline Localization & $\begin{array}{l}\text { Faciobrachio- } \\
\text { crural deficit }\end{array}$ & $\begin{array}{l}\text { Faciobrachial } \\
\text { deficit }\end{array}$ & $\begin{array}{l}\text { Brachiocrural } \\
\text { deftcit }\end{array}$ & Dysarthria \\
ICAL & 1 & 0 & 2 & 1 \\
CN & - & 1 & - & 1 \\
ICPLAP & 2 & 1 & - & 2 \\
ICPL-MP & 2 & - & 2 & 1 \\
ICPL-PP & 5 & - & 1 & 2 \\
CRA & 4 & - & - & 2 \\
CRP & 8 & 1 & 5 & - \\
LN & 0 & - & 1 & 1 \\
\hline
\end{tabular}

Table 8.4 shows the correlation between infarct localization, and type of motor deficit and dysarthria. There were no clear correlations.

PMS (Fig.8.1, Table 8.2)

Six lacunar infarcts causing PMS were located throughout the posterior limb of the in ternal capsule. The three infarcts in the anterior part of posterior limb extended into the corona radiata. Two infarcts were located in the anterior limb, extending into the caudate nucleus. One infarct was confined to the caudate nucleus. Nine infarcts were situated in the corona radiata (three continuing into the lentiform nucleus), eight of which were located in the posterior part.

SMS (Fig. 8.1, Table 8.2)

Seven infarcts were located in the posterior limb of the internal capsule, one continuing in the corona radiata. All these seven infarcts were located in the posterior two thirds of the posterior limb. There was some thalamic involvement in two of 
them (thalamocapsular infarct). One infarct was located in the anterior limb of the internal capsule, extending into the caudate nucleus. Nine infarcts were situated in the corona radiata; six of these were located in the posterior part of the corona radiata. One infarct was confined to the lentiform nucleus.

\section{AH (Fig. 8.1, Table 8.2)}

Five infarcts were located in the posterior limb of the internal capsule; in three of these, either the thalamus, lentiform nucleus or corona radiata was also involved. Four infarcts were situated in the corona radiata, three of which in the posterior part. One infarct was located in the thalamus and three in the lentiform nucleus.

PSS (Fig. 8.1, Table 8.2)

One patient had thalamic infarction.

\section{Discussion}

One might expect that patients with SMS have a higher positive CT rate and a larger volume of the infarcts than patients with PMS, because neurological signs are more extensive in patients with SMS. However, there was no difference in the frequency of positive CT amongst our patients with PMS and SMS, nor were there significant differences in infarct-volume between the different lacunar syndromes. Others did not find a correlation between the lacunar syndromes and detection rate on CT or volume of the infarcts either. ${ }^{80,120}$

Most infarcts (68\%) were located in the territory of the anterior choroidal artery. Two previous studies, also using Damasio's brain templates, reported involvement of the anterior choroidal artery territory in a minority (23\%) of the patients with lacunar infarcts ${ }^{80,138}$ Patients with anterior choroidal artery infarction are reported to present with hemiparesis, hemisensory loss and often visual field deficit. ${ }^{30,97,98}$ We found that they can present with PMS, SMS or AH.

\section{PMS}

PMS, the syndrome of unilateral pure motor deficit, can be caused by lacunar infarction anywhere along the corticospinal pathway from the cerebral cortex to the medullary pyramid. ${ }^{60}$ The syndrome is usually caused by lacunes in internal capsule, ${ }^{52,60,161,172,216,217}$ corona radiata ${ }^{52,161,216}$ or pons, ${ }^{60,199}$ but lacunes in lentiform nucleus, ${ }^{161,217}$ cerebral peduncle ${ }^{105}$ and medullary pyramid ${ }^{39,133,177}$ have been described. Nine of our patients with PMS had an infarct in the corona radiata, eight of which were located in the posterior part close to the centre. This means that the corticospinal pathway runs in the posterior part close to the centre of the corona radiata. This clinical finding concurs with a post-mortem dissection study. ${ }^{181}$

It was demonstrated that the corticospinal tract runs through the posterior half of the posterior limb of the internal capsule. . $1,26,37,54,93,103,149$ We found seven infarcts located in the posterior limb of the internal capsule. However, the lesions were not only situated in the posterior part of the posterior limb: three infarcts were located in the 
anterior part of the posterior limb, rostral at the junction of corona radiata and internal capsule. Obviously, the corticospinal pathway has an oblique course in the internal capsule: it runs from the sensorimotor cortex, via the posterior part of the corona radiata, to the anterior half of the posterior limb and then progressively shifts into the posterior half of the posterior limb in the more caudal part of the internal capsule. This clinical finding is in agreement with the post-mortem findings of Ross. ${ }^{1 \text { in }}$

Fibers in the corticospinal tract are said to show somatotopical arrangement in the posterior limb of the internal capsule which, however, is not sharp. ${ }^{26,37,14 i}$ Fibers to the motor cells of the face and arm lie more anteriorly, while those supplying the trunk and leg lie more posteriorly in the capsule. However, it is not possible to demonstrate somatotopical arrangement in clinical studies due to the oblique course of the corticospinal pathway in the internal capsule.

Two patients with PMS had lacunar infarction in the anterior limb of the internal capsule, extending into the caudate nucleus. One patient had an infarct confined to the caudate nucleus. These anterior capsulo-caudate or caudate infarcts were also found by others in patients with PMS. ${ }^{52,172,201}$ Fisher reported three patients with PMS in whom autopsy revealed lacunes in genu or anterior limb. ${ }^{69}$ Weakness of the right arm with sudden loss of speech after infarction of the head of putamen and caudate nucleus and anterior half of the anterior limb of the internal capsule, was described by Critchley. ${ }^{41}$ The infarct was caused by occlusion of Heubner's artery. Caplan et al ${ }^{36}$ reported on 18 patients with caudate nucleus infarcts, extending into the anterior limb in 9 patients. Motor dysfunction was present in 13 of 18 patients. How can these infarcts cause motor dysfunction? The anterior limb of the internal capsule contains the frontal corticopontine (frontopontine) tract, the corticostriatal projection, and the anterior thalamic radiation. ${ }^{26,37}$ The anterior thalamic radiation is not involved in motor control. ${ }^{26,37}$ The fibers of the corticopontine tract arise from the frontal, temporal, parietal and occipital regions of the cerebral cortex and terminate in the ipsilateral pons. ${ }^{26,37}$ From here fibers go mainly to the contralateral cerebellum. The corticopontine tract has an important function in motor control. ${ }^{26} \mathrm{It}$ was shown in the monkey that all major cortical areas project upon the caudate nucleus and putamen by the corticostriatal projection, ${ }^{26}$ relating the sensorimotor cortex to the head of the caudate nucleus and putamen. Caudate nucleus and putamen project to the substantia nigra (striato-nigral fibers) and to globus pallidus. Globus pallidus sends fibers to substantia nigra (pallidonigral projection), which influences the sensorimotor cortex via two pathways: the nigrothalamic projection to the ventrolateral thalamus, and the nigrostriatal projection via striatum and globus pallidus to the ventroanterior thalamus. The ventrolateral and ventroanterior thalamus project to the sensorimotor cortex by way of the superior thalamic radiation, that runs in the posterior limb of internal capsule. This circuit is supposed to be involved in motor control. Therefore, paresis in our patients with anterior capsulo-caudate or caudate infarction could be caused by interruption of the frontopontine tract, the corticostriatal projection, or both. Another possibility is that these infarcts were asymptomatic while the symptomatic infarcts were too small to be visible on CT. This last explanation seems unlikely because these infarcts were also reported by others, $36,52,172,201$ 
and found by Fisher at autopsy: ${ }^{69}$

\section{SMS}

SMS, the syndrome of unilateral motor and objective sensory loss, ${ }_{p}^{7,150}$ can be caused by lacunar infarction interrupting corticospinal together with sensory thalamocortical pathways. In our study, SMS occurred with lacunar infarction in the anterior or posterior limb of internal capsule, thalamocapsular region, corona radiata and lentiform nucleus. Previous reports on SMS described lacunes in anterior and posterior limb of the internal capsule, ${ }^{110}$ corona radiata, ${ }^{110}$ thalamus (ventral posterior nucleus with capsular pallor), ${ }^{150}$ thalamocapsular region, ${ }^{10,176}$ lentiform nucleus extending up to the corona radiata, ${ }^{52}$ and in the caudatoputaminal-capsular region. ${ }^{217}$ Nine of our patients with SMS had an infarct in the corona radiata, of which three were located in the anterior part and six in the posterior part, all close to the centre. This means that the sensory thalamocortical pathway is located around the centre of the corona radiata, close to the corticospinal pathway.

The sensory part of the thalamocortical pathway is supposed to run in the posterior limb of the internal capsule but the precise localization is not clear. ${ }^{26,37}$ Groothuis et al. suggested, from one case of a small capsular hemorrhage causing a PSS, that the thalamocortical pathway runs posteriorly in the posterior limb adjacent to the thalamus. ${ }^{8}$ We found that seven patients had an infarct in the posterior limb of the internal capsule. All these infarcts were situated in the posterior part of the posterior limb; in two patients the infarct extended into the thalamus (thalamocapsullar infarct). Our findings indicate that the thalamocortical pathway is indeed located in the posterior part of the posterior limb of the internal capsule. In the patients with thalamocapsular infarction, the thalamocortical pathway could also have been interrupted at the ventral posterolateral nucleus. The occurrence of sensory loss after infarction of the anterior limb of the internal capsule in one patient is hard to understand. The anterior limb contains the anterior thalamic radiation, connecting the frontal lobe with the medial and anterior thalamic nuclei. ${ }^{37}$ These nuclei are supposed to be involved mainly in the limbic system and not in the sensory system, but, according to our finding (one patient), the anterior thalamic radiation, although unlikely, might contain sensory fibers. Local edema compressing the thalamocortical pathway in the posterior limb is possible but unlikely. Another possibility is that the infarct was asymptomatic, and that the symptomatic one was small and not visibles on CT. In the series of Huang et al, , one patient had SMS after anterior limb infarction but a neuro-anatomical explanation was not given. ${ }^{110}$ The infarct in the lentiform nucleus was located adjacent to the posterior limb of the internal capsule. Probably, local edema compressed the corticospinal and thalamocortical pathways in the posterior limb in this case.

\section{AH}

AH consists of hemiparesis and so-called "cerebellar-like" ataxia on the same side of the body ${ }^{7,62,63,68}$ It includes also dysarthria-clumsy hand syndrome cases. ${ }^{770}$ AH may be caused by lacunar infarction in the contralateral posterior limb of the internal capsule, the pons or in the corona radiata. $28,45,47,52,68,99,100,108_{s} 112,114,116,117,127,161,167,167_{1}, 195,217$ 
Hemiparesis is due to interruption of the corticospinal pathway. Some mechanisms may be responsible for the cerebellar-like ataxia: interruption of cerebellarcortical (dentato(rubro)thalamocortical) or corticocerebellar (corticopontocerebellar) pathways, or impaired proprioception. Impaired proprioception is unlikely because only two of our patients had impaired proprioception on clinical testing; furthermore, only 2 of 16 patients with $\mathrm{AH}$ had a disturbed somatosensory evoked potential (unpublished data). It is most likely that the ataxia was caused by supratentorial interruption of cerebellarcortical or corticocerebellar pathways. This is supported by cetebral blood flow studies showing functional hypometabolism of the contralateral cerebellar hemisphere in supratentorial infarcts, the so-called crossed cerebellar diaschisis. ${ }^{78,166}$. This phenomenon is ascribed to interruption of corticocerebellar pathway, leading to a loss of excitatory input in the contrallateral cerebellar hemisphere.

One of our patients had AH following lacunar infarction strictly confined to the ventrolateral part of the thalamus, involving the ventrolateral nucleus. This patient is reported in detail in Chapter 9. Cerebellar ataxia in this patient could have been caused only by interruption of the dentato(rubro)thalamocortical fibers at the level of the injured ventrolateral nucleus. Hemiparesis was probably caused by initial local edema compressing the adjacent corticospinal tract in the posterior limb of the internal capsule. However, it is clinically not possible to determine whether cerebellar symptomatology is caused by interruption of cerebellarcortical or corticocerebellar pathways, or both.

Our study showed lacunes in posterior limb of internal capsule, thalamocapsular region, corona radiata, lentiform nucleus and thalamus. Four patients with $\mathrm{AH}$ had lacunar infarction in the corona radiata, close to the centre. This means that the cerebellar pathways are localized around the centre of the corona radiata. The exact locations of these cerebellar path ways in the posterior limb of the internal capsule are not known. ${ }^{26,37}$ An infarct in the posterior limb of the internal capsule was shown in four patients and one patient had a thalamocapsular infarct. The infarcts were located in the posterior part of the posterior limb. According to these findings, the cerebellar pathways are located in the posterior part of the posterior limb. The thalamocapsular infarct probably injured the dentato(rubro) thalamocortical fibers at the level of the ventrolateral thalamic nucleus. Three infarcts were located in the lentiform nucleus, rather close to the posterior limb of the internal capsule. An explanation for AH following these infarcts is initial local edema compressing the adjacent corticospinal and cerebellar pathways in the posterior limb of the internal capsule. Neurological signs resolved in a few days in these three patients, which supports this assumption.

\section{PSS}

One patient with PSS had lacunar infarction of the thalamus. PSS consists of a unilateral sensory deficit. ${ }^{7{ }^{61}}$ Originally, Fisher found lacunes in the posteroventral thalamus at autopsy. ${ }^{61,67}$ Usually, $\mathrm{CT}$ shows no lacunar infarction in patients with PSS, because the infarcts are probably too small to be visualized by $\mathrm{CT}_{3}^{71}$ but lacunes on CT or MRI have been shown in thalamus, ${ }^{86,131,176,185}$ in thalamocapsular region ${ }^{217}$ and in the pons. ${ }^{106}$ Thalamic infarction in our patient caused a PSS by interrupting the sensory pathway at the level of the nucleus ventralis posterolateralis. 
Ataxic hemiparesis following thalamic infarction

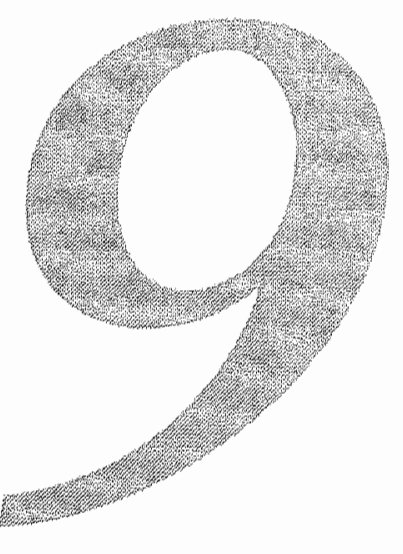





\section{Introduction}

Ataxic hemiparesis (AH), first described by Fisher and Cole ${ }^{62}$ in 1965 , consists of hemiparesis and cerebellar ataxia on the same side of the body. ${ }^{68} \mathrm{AH}$ is usually caused by lacunar infarction in the contralateral posterior limb of the internal capsule, in the pons, or in the corona radiata, ${ }^{62,68,108,187}$ but may also be caused by a hemorrhage or a tumor. ${ }^{13,100,156}$

We report a case of ataxic hemiparesis in which CT and MRI showed an infarct in the contralateral ventrolateral nucleus of the thalamus.

\section{Case report}

A 73-year-old man suddenly developed dysarthria and weakness of right arm and leg with unsteadiness of gait. There was no history of hypertension, diabetes, cardlac disease or peripheral vascular disease. On examination the next day, he had a regular pulse of $76 / \mathrm{min}$. Blood pressure was $150 / 80 \mathrm{~mm} \mathrm{Hg}$. There were no carotid bruits, and cardiac examination was normal. He was alert and fully oriented. Neurological examination showed a slight rightsided hemiparesis with extensor plantar response. Finger-to-nose and heel-to-shin tests showed cerebellar type right-sided dysmetria, hypermetria and intention tremor out of proportion to the degree of weakness. Sensation was normal. His hemiparesis disappeared after 4-5 days, while his ataxia persisted. After 4 weeks there was only clumsiness of his right hand, with slight ataxia on the finger-to-nose test. Results of electrocardiography, 24 hour-electrocardiographic (Holter) monitoring, echocardiography and duplex carotid sonography were normal. Serum cholesterol concentration was slightly elevated.

CT scan on day 4 revealed a hypodense lesion in the ventrolateral nucleus of the contralateral thalamus, compatible with a recent infarction (Fig. 9.1). MRI 1 year later showed the same infarct in the left thalamus (Fig. 9.2). There were no other lesions visible in the internal capsule, corona radiata, brainstem, or cerebellum.

\section{Discussion}

"Painful ataxic hemiparesis" following thalamic infarction and "hypesthetic ataxic hemiparesis" in thalamic hemorrhage and infarction have been reported. ${ }^{18,132,213}$ Solle unilateral cerebellar ataxia has been described following contralateral thalamic infarction. ${ }^{74,75}$ Murthy ${ }^{158}$ described a case of ataxic hemiparesis following thalamic infarction, but the lesion appeared to be located in the head of the caudate nucleus instead of the thalamus. ${ }^{84}$ CT and MRI in our patient showed an infarct in the contralateral thalamus. To our knowledge, this is the first reported case of classical ataxic hemiparesis following infarction strictly confined to the thalamus.

The lesion was located in the ventrolateral part of the thalamus, with involvement of the ventrolateral nucleus. From experimental evidence it was concluded that the ventrolateral nucleus receives fibers from the contralateral cerebellar dentate nucleus 


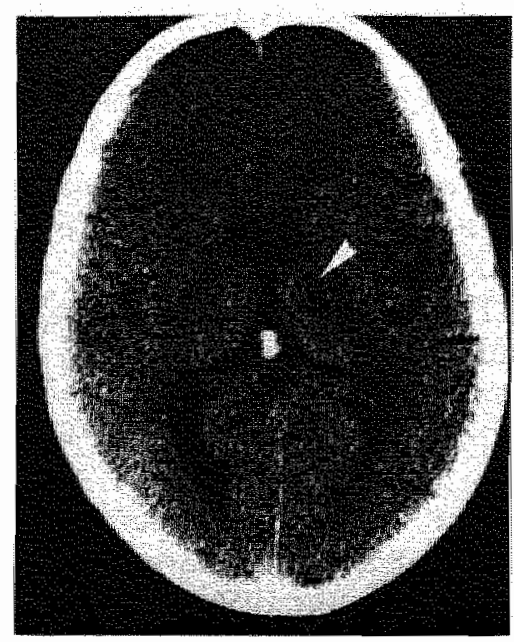

Figure 9.1 CT scan showing a hypodense lesion in the ventrolateral part of the thalamus, with involvement of the ventrolateral nucleus (arrow).

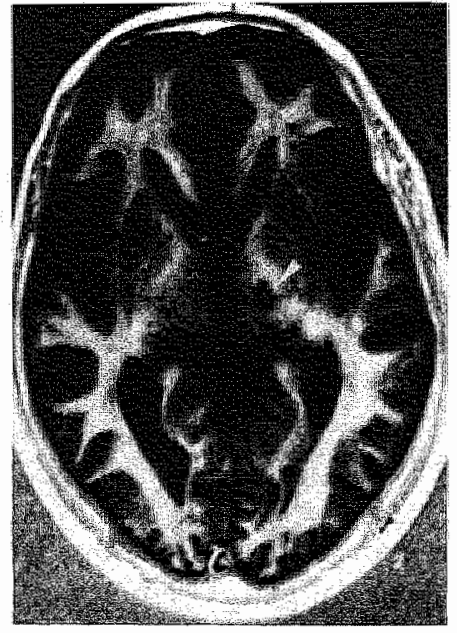

Figure 9.2 MRI after one year showing the same lesion in the left thalamus (arrow).

(the dentatorubrothalamic projection). ${ }^{26}$ From the ventrolateral nucleus, fibers run to the sensorimotor cortex ${ }^{26}$ Cerebellar ataxia in our patient was most likely caused by interruption of the dentatorubrothalamocortical fibers at the level of the injured ventrolateral nucleus. Hemiparesis was probably caused by initial local edema compressing the adjacent corticospinal tract in the posterior limb of the internal capsule because MRI did not reveal involvement of the internal capsule. The hemiparesis clearing much more rapidly than the hemiataxia, supports this assumption. Our case illustrates that the ventrolateral part of the thalamus takes part in the cerebellar projection to the sensorimotor cortex, disruption of which at different levels can induce the classic lacunar syndrome of ataxic hemiparesis. 


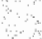

$\therefore$

a 


\section{General discussion}

Lacunar infarcts represent a numerically important subgroup of ischemic strokes because $41 \%(95 \% \mathrm{Cl} 35-47 \%)$ of all our patients with a first-ever supratentorial brain infarct had lacunar infarction.

We used CT as gold standard in our definition of lacunar infarction, although CT has the limitation that small lacunes may not be visualized. Autopsy and MRI are likely to be superior to CT in detecting lacunar infarcts. However, due to the low early case fatality rate, autopsy is not a feasible method to study lacunar stroke. The low availability of MRI at present limits its use in large clinical studies.

We defined lacunar infarction with or without a lesion on CT images in a patient presenting with a lacunar syndrome. One could criticize this definition because patients without a lesion on CT might not have had a lacunar infarct. However, risk factor profile did not differ between lacunar infarct patients with and without a CT lesion in a large series from the Oxfordshire Community Stroke Project. Moreover, it was shown that patients with a lacunar syndrome and normal CT often had lacunar infarction on MRI. Therefore, lacunar stroke patients with and without a lesion on CT are not qualitatively different. Defining lacunar infarction based on the presence of a CT lesion would create a bias towards inclusion of larger lacunes.

This study supports the lacunar hypothesis: the four lacunar syndromes of PMS, PSS, AH and SMS are a good or even excellent clinical test to diagnose lacunar infarction. The other reported lacunar syndromes are uncommon, and the lack of clinicopathologic correlation makes them less suitable for clinical studies on lacunar infarction. Our findings show that cardiac and carotid embolism are unlikely causes of lacunar infarction, supporting the second part of the lacunar hypothesis, which is that lacunar infarcts are usually caused by small vessel disease.

According to our findings, a third ellement should be added to the lacunar hypothesis, namely that two distinct lacunar stroke entities can be distinguished: firstly, the group of patients with multiple lacunar infarcts and a high frequency of hypertension and leuko-araiosis who presumably have lipohyalinosis, and secondly, those with a single symptomatic lacunar infarct without leuko-aralosis who presumably have microatheromatous disease. Leuko-araiosis and progressive cognitive dysfunction are therefore related to the lipohyalinosis type of small vessel disease rather than to microatheromatous disease.

In our prospective clinical study, approximately $80 \%$ of all lacunar stroke patients presumably have microatheromatous disease and approximately $20 \%$ lipohyalinosis. Most clinical studies deal with symptomatic lacunar stroke, and therefore include mainly patients suffering from microatheromatous disease rather than from lipohyalinosis. This could explain that a significant number of lacunar stroke patients 
in clinical studies were without hypertension. The fact that hypertension is not more prevalent in lacunar stroke patients than in cortical stroke patients may merely reflect the low number of patients with lipohyalinosis in clinical studies.

This study clearly shows that lacunar infarction should be considered a separate subgroup among cerebral infarction. First, the natural history of patients with lacunar infarction was different from that in patients with atherothrombotic infarction involving the cortex. Second, almost $90 \%$ of recurrent infarcts in patients with lacunar infarction were again lacunar ${ }_{\nu}$ supporting a distinct underlying vasculopathy. Third, potential cardiac and carotid sources of embolism were significantly less frequent in patients with lacunar infarction than in patients with infarction involving the cortex. Fourth, Ieuko-araiosis was more common in patients with lacunar infarction than in patients with cortical infarction.

The conclusion of lacunar infarcts being a separate subgroup caused by small vessel disease has consequences for their management and therapy. Our finding that potential cardiac and carotid sources of embolism are unlikely causes of lacunar infarction, and probably only coincidental in these patients means that they should, in general, not undergo extensive cardiac examination or angiography, and that they should not be treated with anticoagulation or carotid endarterectomy to prevent further strokes.

Platelet antiaggregating drugs are part of the current treatment to prevent further strokes in patients with atherothrombotic infarcts, including lacunar infarcts. However, to demonstrate the efficacy of these drugs in lacunar infarct patients, they should be studied separately in future cerebral infarct treatment trials. These antithrombotic drugs may be useful in patients suffering from the microatheromatous type of small vessel disease, but may be less useful in those suffering from the lipohyalinosis type. Therefore, if the two distinct lacunar stroke entities reflect indeed the two types of small vessel disease, patients belonging to the two lacunar stroke entities should also be distinguished in these treatment trials.

This study presents evidence that lacunar stroke patients who suffer from lipohyalinosis can probably be recognized during life. This is important because this could provide the possibility of recognizing those patients who are at risk to develop eventually subcortical vascular dementia. Hypertension seems to be the major important risk factor for lipohyalinosis, treatment of which may substantially reduce the risk of eventual subcortical vascular dementia. However, more, especially longterm, studies are needed to support these findings. 


\section{Summary}

The aim of this thesis has been to describe some clinical and radiological aspects of lacunar infarction in a well-defined prospective series.

In Chapter 1, the relevant literature on lacunar infarcts is reviewed. After some general remarks, the lacunar hypothesis, pathogenesis of lacunar infarction, the lacunar syndromes, and leuko-araiosis are discussed. Lacunar infarcts are small infarcts located in the deep parts of the brain, or in the brainstem, which are caused by occlusion of one small perforating artery. The lacunar hypothesis suggests that lacunar syndromes usually result from lacunar infarcts, and that these infarcts are usually caused by a distinct vasculopathy of the small perforating arteries. There is a good clinicopathological correlation: autopsy confirmed the presence of lacunar infarcts in PMS, PSS, AH, and SMS. Although a good positive predictive value of these four syndromes in diagnosing lacunar infarction has been reported, the overall clinical usefulness of the lacunar syndromes has not definitely been established until now. Furthermore, due to the scarcity of neuropathological studies, large clinical studies are needed to confirm the probability that lacunar infarcts are caused by small vessel disease. Periventricular diffuse white matter lucencies on CT are called leukoaraiosis. Autopsy showed possible small vessel disease in patients with leuko-araiosis, but clinical studies have to show that leuko-araiosis is related to lacunar infarction.

In Chapter 2, we have studied in a prospective series of 103 patients with a first-ever lacunar infarct and 144 patients with a first-ever infarct involving the cortex, the validity of the lacunar syndromes in diagnosing lacunar infarction, and we have compared the natural history in patients with a lacunar infarct, with that in patients with a cortical infarct. The pretest probability of lacunar infarction was $41 \%$. Positive and negative predictive values of diagnosing lacunar infarction in patients with lacunar syndromes were $90 \%$ and $97 \%$, respectively. Obviously, the lacunar syndromes are a good or even excellent clinical test to diagnose lacunar infarction. Kaplan-Meier analysis showed that patients with lacunar infarction had better survival during mean follow-up of 11 months than patients with atherothrombotic infarction involving the cortex $(p=0.0002)$, whereas the risk of recurrent infarction did not differ between the two groups $(p=0.08)$. Patients with lacunar infarction had better survival free of recurrent infarction than patients with atherothrombotic infarction $(\mathrm{p}=0.002)$. Six of the seven $(86 \%)$ recurrent infarcts in the lacunar infarction group were lacunar again, supporting the hypothesis that lacunar infarcts are usually caused by small vessel disease, occluding the small perforating arteries. 
In Chapter 3, seven of 252 patients (3\%; $95 \%$ Cl 1-5\%) with a first-ever supratentorial brain infarct had acute isolated monoparesis without signs of cortical dysfunction. Prognosis was favourable with complete recovery within two to four weeks. In six patients, CT showed a small infarct involving the cortex and adjacent subcortex in the territory of the middle cerebral artery, whereas no lesion was visualized in one patient. None of the patients had lacunar infarction on CT. These findings show that isolated monoparesils is usually caused by small infarcts involving the cortex. Isolated monoparesis, therefore, is not a lacunar syndrome.

In Chapter 4, we have tested the hypothesis that if lacunar infarction is usually caused by small vessel disease, the frequency of potential cardiac and carotid sources of embolism would be lower in patients with lacunar infarcts than in patients with infarcts involving the cortex. We have also determined the frequency of vascular risk factors (hypertension, diabetes mellitus and history of ischemic heart disease). Risk factor analysis showed no differences between both infarct groups. A cardiac source of embolism was significantly less common in patients with lacunar infarction (OR $0.32 ; 95 \% \mathrm{CI} 0.17-0.61 ; \mathrm{p}<0.001)$. Significant stenosis of the ICA was also less common in patients with lacunar infarction (OR 0.35;95\% CI 0.16-0.76; $\mathrm{p}<0.001$ ). These findings strongly suggest that cardiac and carotid embolism are unlikely causes of lacunar infarction, supporting the hypothesis that lacunar infarcts are usually caused by small vessel disease.

In Chapter 5, we have tested the hypothesis that if lacunar infarction and leukoaraiosis are both caused by small vessel disease, leuko-araiosis would be more frequent in patients with lacunar infarction than in patients with infarction involving the cortex. We have also determined the frequency of vascular risk factors in patients with and without leuko-araiosis. Leuko-araiosis was significantly more common in patients with lacunar infarction (OR 1.82; 95\% CI 1.00-3.45; $\mathrm{p}=0.05$ ). Patients with leuko-araiosis were significantly older ${ }_{f}$ whereas frequency of vascular risk factors did not differ in patients with and without leuko-araiosis. Our findings show that leukoaraiosis is associated with small vessel disease in stroke patients.

In Chapter 6, we investigated in 100 lacunar stroke patients whether patients with one or more asymptomatic lacunar infarcts, and those with only symptomatic lacunar infarction represent two distinct clinical entities, probably reflecting lipohyalinosis and microatheromatous disease. Seventy-nine patients had one symptomatic lacunar infarct and 21 patients also had one or more asymptomatic lacunar infarcts. Patients with asymptomatic lacunar infarcts had significantly more often hypertension (OR 3.31; 95\% CI 1.16-9.43; p<0.05) and leuko-araiosis (OR 10.67; $95 \% \mathrm{Cl} 3.81-32.10 ; \mathrm{p}<0.001)$ than those with a single, symptomatic lacunar infarct. The asymptomatic lacunar infarcts differed in location, involved vascular territory and volume from the symptomatic ones. We hypothesize that indeed two distinct lacunar stroke entities can be distinguished during life: lacunar stroke patients with a single, symptomatic lacunar infarct who presumably have microatheromatous small vessel disease, whereas patients with multiple lacunar infarcts, and a high 
frequency of hypertension and leuko-araiosis probably have small vessel lipohyalinosis. Differentiating between the two lacunar stroke entities is important because this could provide the possibility of recognizing those patients who are at risk to develop eventually subcortical vascular dementia. Hypertension seems to be the major important risk factor for lipohyalinosis, treatment of which may substantially reduce the risk of eventual subcortical vascular dementia.

In Chapter 7 , fifteen of 252 patients $(6 \% ; 95 \% \mathrm{CI} 3-9 \%)$ with a first-ever supratentorial brain infarct, had a large subcortical infarct. Twelve ( $80 \%$; $95 \% \mathrm{Cl} 20-100 \%)$ had signs of cortical dysfunction, whereas risk factor profile, frequency of significant carotid stenosis, and frequency of potential cardioembolic sources did not differ from those with cortical infarction. Compared with lacunar infarct patients, they more frequently had a potential cardioembolic source and significant carotid stenosis. These findings show that large subcortical infarcts differ from lacunar infarcts with regard to both presenting signs and symptoms, and pathogenesis, whereas they resemble infarcts involving the cortex. Obviously, large subcortical infarcts are not lacunar.

In Chapter 8, detailed CT findings in a prospective series of 98 patients with a firstever lacunar infarction are reported, allowing determination of the course of the corticospinal, thalamocortical and cerebellar pathways at the level of internal capsule and corona radiata, by correlating the infarct localization with the clinical symptoms. Approximately $60 \%$ of the patients had a lacunar infarct on CT. Eighty-six percent of the infarcts were located in internal capsule and corona radiata. Most infarcts (68\%) were located in the territory of the anterior choroidal artery. Our findings demonstrate that the corticospinal (pyramidal) tract runs from the sensorimotor cortex through the posterior part of the corona radiata, to the anterior half of the posterior limb and then progressively shifts into the posterior half of the posterior limb in the more caudal part of the internal capsule. Paresis after anterior capsulo-caudate or caudate infarction is probably caused by interruption of the frontopontine tract or the corticostriatal projection, or both. Both thalamocortical and cerebellar pathways (dentato(rubro)thalamocortical and corticopontocerebellar pathways) are located around the centre of the corona radiata and in the internal capsule in the posterior part of the posterior limb.

In Chapter 9, the first reported case of classic ataxic hemiparesis following thalamic infarction is described, illustrating that the ventrolateral part of the thalamus takes part in the cerebellar projection to the sensorimotor cortex.

In the General discussion, we conclude that this study supports the lacunar hypothesis by demonstrating that the lacunar syndromes are a good or even excellent clinical test to diagnose lacunar infarction, and that lacunar infarcts are usually caused by small vessel disease. Furthermore, a third element should be added to the lacunar hypothesis, namely that two distinct lacunar stroke entities can be distinguished. It is obvious that lacunar infarcts should be considered a separate subgroup among cerebral infarction, which has consequences for their management and therapy. 



\section{Samenvatting}

In dit proefschrift worden bij een prospectieve serie patiënten enkele klinissche en radiologische aspecten van lacunaire herseninfarcten beschreven.

In hoofdstuk 1 wordt een overzicht gegeven van de relevante literatuur over lacunaire infarcten. $\mathrm{Na}$ enkele algemene opmerkingen over lacunaire infarcten, worden achtereenvolgens de lacunaire hypothese, de pathogenese van lacunaire infarcten, de lacunaire syndromen en leuko-araiosis besproken. Lacunaire infarcten zijn kleine infarcten die diep in de hersenen of in de hersenstam zijn gelokaliseerd en die worden veroorzaakt door een afsluiting van één der kleine perforerende hersenarteriën. De lacunaire hypothese stelt dat de lacunaire syndromen meestal het gevolg zijn van lacunaire infarcten, en dat deze lacunaire infarcten meestal worden veroorzaakt door een vaataandoening van de kleine perforerende hersenarterièn. Lacunaire syndromen zijn de complexen van neurologische uitvalsverschijnselen die veroorzaakt kunnen worden door een lacunair infarct. Er bestaat een goede klinisch-pathologische correlatie: pathologisch-anatomisch onderzoek heeft lacunaire infarcten aangetoond bij patiënten met een zuiver motorisch syndroom, een zuiver sensibel syndroom, een motorisch-sensibel syndroom of een atactisch-motorisch syndroom. Ofschoon er een goede positieve voorspellende waarde van deze vier lacunaire syndromen met betrekking tot het diagnostiseren van lacunaire infarcten is beschreven, is de klinische bruikbaarheid van deze lacunaire syndromen nog steeds niet definitief vastgesteld. Bovendien moet in klinische studies bevestigd worden dat lacunaire infarcten meestal worden veroorzaakt door een aandoening van de kleine perforerende hersenarteriën. Diffuse hypodensiteit van de witte stof op een CT scan wordt leuko-araiosis genoemd. Weliswaar werd bij pathologisch-anatomisch onderzoek een aandoening van de kleine perforerende hersenarteriën gevonden bij patiënten met leuko-araiosis, maar ook in klinische studies zal onderzocht moeten worden of leukoaraiosis en lacunaire infarcten inderdaad aan elkaar gerelateerd zijn.

In hoofdstuk 2 wordt in een prospectieve studie bij 103 patiënten met een eerste lacunair infarct en 144 patiënten met een eerste corticaal infarct de diagnostische waarde van de lacunaire syndromen met betrekking tot het diagnostiseren van lacunaire infarcten onderzocht. Daarnaast werd het klinisch beloop en de prognose van de patiënten met een lacunair infarct vergeleken met die van patiënten met een corticaal infarct. De prevalentie van lacunaire infarcten was $41 \%$. De positieve en negatieve voorspellende waarde van het diagnostiseren van lacunaire infarcten bij patiënten met een lacunair syndroom was respectievelijk $90 \%$ en $97 \%$. De lacunaire syndromen zijn dus een goede diagnostische test om lacunaire infarcten te dia- 
gnostiseren. Kaplan-Meier analyse liet zien dat patiënten met een lacunair infarct een betere overleving hebben dan patiënten met een atherothrombotisch corticaal infarct gedurende een gemiddelde follow-up van 11 maanden ( $p=0.0002)$, terwijl het aantal recidief infarcten niet verschilde tussen beide groepen $(p=0.08)$. Patiënten met een lacunair infarct hadden een betere overleving zonder recidief infarct dan patienten met een atherothrombotisch corticaal infarct $(\mathrm{p}=0.002)$. Opmerkelijk was dat zes van de zeven $(86 \%)$ recidiefinfarcten in de groep van patiënten met een Jacunair infarct opnieuw lacunair waren. Dit gegeven ondersteunt de hypothese dat lacunaire infarcten meestal worden veroorzaakt door een aandoening van de kleine perforerende hersenarterien.

In hoofdstuk 3 bleken 7 van de 252 patiënten (3\%; 95\% BI 1-5\%) met een eerste, supratentoriëel gelokaliseerd herseninfarct een acute monoparese te hebben zonder tekenen van corticale dysfunctie. In zes van deze patiënten liet de CT scan een klein corticaal infarct zien in het stroomgebied van de a.cerebri media. Bij één patiënt toonde de CT scan geen afwijkingen. Geen enkele patiënt had een lacunair infarct. Deze bevindlingen laten zien dat een acute monoparese meestal wordt veroorzaakt door een klein corticaal infarct. Acute monoparese is daarom geen lacunair syndroom.

In hoofdstuk 4 hebben we de volgende hypothese onderzocht: als lacunaire infarcten meestal worden veroorzaakt door een aandoening van de kleine perforerende hersenarteriën, dan zullen potentiële cardiale en carotis emboliebronnen bij patiënten met een lacunair infarct minder vaak voorkomen dan bif patiënten met een corticaal infarct. Tevens onderzochten we het voorkomen van de vasculaire risicofactoren (hypertensie, diabetes mellitus en ischemische hartziekte in de voorgeschiedenis). Deze risicofactoren kwamen evenveel voor in beide infarctgroepen. Een potentiële cardiale emboliebron kwam significant minder vaak voor bij patiënten met een lacunair infarct (OR $0.32 ; 95 \%$ BI $0.17-0.61 ; \mathrm{p}<0.001)$. Een significante stenose van de a. carotis interna (diameter reductie groter of gelijk aan $50 \%$ ) kwam eveneens minder vaak voor bij patiënten met een lacunair infarct (OR $0.35 ; 95 \% \mathrm{BI}$ $0.16-0.76 ; p<0.001)$. Deze bevindingen suggereren dat cardiale en carotis embolieën een onwaarschijnliike oorzaak zijn van lacunaire infarcten, hetgeen de hypothese ondersteunt dat lacunaire infarcten meestal worden veroorzaakt door een aandoening van de kleine perforerende hersenarteriën.

De hypothese dat indien lacunaire infarcten en leuko-araiosis beide veroorzaakt worden door een aandoening van de kleine perforerende hersenarteriën, leukoaraiosis meer zal voorkomen bij patiënten met een lacunair infarct dan bij patiënten met een corticaal infarct, werd onderzocht in hoofdstuk 5 . Tevens werd het voorkomen van vasculaire risicofactoren bij patiènten met en zonder leuko-araiosis onderzocht. Leuko-araiosis kwam significant vaker voor bij patiënten met een lacunair infarct dan bij patiënten met een corticaal infarct (OR $1.82 ; 95 \%$ BI $1.00-3.45 ; \mathrm{p}=0.05$ ). Patiënten met leuko-araiosis waren significant ouder, terwijl het voorkomen van vasculaire risicofactoren niet verschilde bij patiënten met en zonder leuko-araiosis. Hieruit blijkt dat leuko-araiosis samenhangt met een aandoening van de kleine 
perforerende hersenarteriën bij patiënten met een herseninfarct.

In hoofdstuk 6 hebben we in 100 patiënten met een lacunair infarct onderzocht of de patiënten met meerdere lacunaire infarcten en degenen met eén symptomatisch lacunair infarct, twee verschillende lacunaire infarct entiteiten vertegenwoordigen, die de klinische representanten zouden kunnen zijn wan respectievelijk lipohyalinose en (micro-)atherosclerose van de kleine perforerende hersenarteriën. Negenenzeventig patiënten hadden één symptomatisch lacunair infarct en 21 patiënten hadden ook éen of meerdere asymptomatische lacunaire infarcten. De patiënten met asymptomatische lacunaire infarcten hadden significant vaker hypertensie (OR $3.31 ; 95 \% \mathrm{BI}$ 1.16-9.43; $\mathrm{p}<0.05$ ) en leuko-araiosis (OR 10.67; 95\% BI 3.81-32.10; $\mathrm{p}<0.001$ ) dan degenen met één symptomatisch lacunair infarct. De asymptomatische infarcten hadden een andere lokalisatie, aangedaan vaatterritorium en volume dan de symptomatische infarcten. Onze hypothese is dat er inderdaad twee verschillende lacunaire infarct entiteiten klinisch kunnen worden onderscheiden: lacunaire infarct patiënten metéén symptomatisch lacunaìr infarct, die waarschijnlijk (micro-)atherosclerose van de kleine perforerende hersenarteriën hebben; en patiënten met meerdere lacunaire infarcten en een hoge frequentie van hypertensie en leuko-araiosis, die waarschijnlijk lipohyalinose van de kleine perforerende hersenarteriën hebben. Het klinisch kunnen onderscheiden van deze twee lacunaire infarct entiteiten is belangrijk omdat dit de mogelijkheid geeft de patiënten te kunnen herkennen die een hoog risico hebben op het ontwikkelen van een subcorticale vasculaire dementie. Hypertensie is waarschijnlijk de belangrijkste risicofactor voor lipohyalinose. Behandeling van de hypertensie kan het risico op mogelijke subcorticale vasculaire dementie verkleinen.

In hoofdstuk 7 bleken vijftien van de 252 patiënten (6\%; $95 \%$ BI 3-9\%) met een eerste supratentoriëel gelokaliseerd herseninfarct een groot subcorticaal infarct te hebben. Twaalf van deze patiënten (80\%; $95 \%$ BI $20-100 \%)$ hadden klinisch corticale uitvalsverschijnselen, terwijl de vasculaire risicofactoren en het voorkomen van significante carotisstenose en potentiële cardiale emboliebron niet verschilden van patiënten met corticale herseninfarcten. Vergeleken met lacunaire infarct patiënten, hadden zij vaker een potentiële cardiale emboliebron en een significante carotisstenose. Deze bevindingen laten zien dat grote subcorticale infarcten verschillen van lacunaire herseninfarcten met betrekking tot zowel klinische verschijnselen als pathogenese, terwijl ze lijken op corticale herseninfarcten. Grote subcorticale infarcten zijn duidelijk niet lacunair.

In hoofdstuk 8 worden de CT scan bevindingen bij 98 prospectief geregistreerde patiënten met een lacunair infarct beschreven. Het verloop van de corticospinale, thalamocorticale en cerebellaire baansystemen werd bepaald op het niveau van de capsula interna en corona radiata door het correleren van de lokalisatie van het infarct met de klinische symptomen. Ongeveer $60 \%$ van de patiënten had een lacunair infarct op de CT scan. Achtenzestig procent van de infarcten wraren gelegen in capsula interna en corona radiata. De meeste infarcten (68\%) bevonden zich in het stroomgebied van de a. choroïdea anterior. Onze bevindingen laten zien dat de tractus 
corticospinalis loopt van de sensomotorische cortex door het achterste gedeelte van de corona radiata naar het woorste gedeelte van het achterste been van de capsula interna, en vervolgens naar het achterste gedeelte van het achterste been in het meer caudale gedeelte van de capsula interna. Parese na infarcering van het voorste been van de capsula interna en/of nucleus caudatus wordt waarschijnlijk veroorzaakt door onderbreking van de tractus frontopontinus of de corticostriatale projectiesystemen, of beide. Zowel de thalamocorticale als de cerebellaire (dentato(rubro) thalamocorticale en corticopontocerebellairel banen zijn gelokaliseerd in het centrum van de corona radiata en in het achterste gedeelte van het achterste been van de capsula interna.

In hoofdstuk 9 wordt het cerste gepubliceerde geval van klassileke atactische hemiparese na infarcering van de thalamus beschreven, waaruit blijkt dat bij de mens de cerebellaire projectie naar de sensomotorische cortex vila het ventrolaterale gedeelte van de thalamus verloopt.

In de algemene discussie concluderen we dat onze studie de lacunaire hypothese ondersteunt omdat de lacunaire syndromen een goede diagnostische test zijn om lacunaire infarcten te diagnostiseren, terwijl bovendien lacunaire infarcten meestal blijken te worden veroorzaakt door een aandoening van de kleine perforerende hersenarteriền. Bovendien zou een derde element aan de lacunaire hypothese moeten worden toegevoegd, namelijk dat er klinisch twee verschillende lacunaire infarct entiteiten kunnen worden onderscheiden. Het is duidelijk dat lacunaire infarcten beschouwd moeten worden als een aparte subgroep van de herseninfarcten, hetgeen consequenties heeft voor beleid en behandeling. 


\section{Appendix}

\section{Definition of lacunar syndromes*}

A constellation of clinical symptoms and signs present at the time of maximal deficit following a single cerebrovascular event. The presence of a visual field defect, evidence of higher cerebral dysfunction (e.g. dysphasia, visuospatial disturbance, predominantly proprioceptive sensory loss) on standard clinical testing, or features that clearly localize the lesion in the vertebrobasilar distribution (e.g. gaze palsies or crossed deficits, though not nystagmus or dysarthria) exclude the diagnosis of lacunar syndrome.

\section{Pure motor stroke}

A unilateral, pure motor deficit involving at least 2 of 3 areas (face, arm, leg) and in patients with faciobrachial or brachiocrural weakness, affecting the whole limb. Sensory symptoms may be present at the time of onset, but there should not be any objective sensory loss on standard clinical testing.

\section{Pure sensory stroke}

A sensory deficit (which may be diagnosed even when there is no objective sensory loss on standard clinical testing) involving at least 2 of 3 areas (face, arm, leg). In patients with faciobrachial and brachiocrural symptoms, the whole limb should be affected. The sensory deficit may include all modalities equally or may spare proprioception.

\section{Ataxic hemiparesis}

A syndrome of ipsilateral corticospinal and cerebellar-like dysfunction without other features that clearly localize to the posterior circulation. This includes cases with predominantly dysarthria and clumsiness of the hand.

\section{Sensorimotor stroke}

A syndrome of ipsilateral motor and objective sensory loss, involving at least 2 of 3 areas (face, arm, leg). In patients with brachiofacial or brachiocrural deficit, the whole limb must be involved. The sensory deficit may involve all modalities equally or may spare proprioception.

* With permission from Bamford et al., Stroke 1987;18:545-551. 


\section{References}

1. Adams HP, Damasio HC, Putman SF, Damasio AR. Middle cerebral artery occlusion as a cause of isolated subcortical infarction. Stroke 1983;14:948-952.

2. Allen $\mathrm{CMC}$. Clinical diagnosis of the acute stroke syndrome. QJ Med 1983;208:515-523.

3. Allen CMC, Harrison MJG, Wade DT. The management of acute stroke. Tunbridge Wells, Castle House Publications Ltd: 1988: 128-139.

4. Anzalone $\mathbb{N}$, Landi $G$. Non ischaemic causes of lacunar syndromes: prevalence and clinical findings. J Neurol Neurosurg Psychiatry 1989;52:1188-1190.

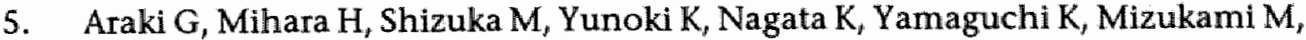
Kawase T, Tazawa T. CT and arteriographic comparison of patients with transient ischemic attacks. Correlation with small infarction of basal ganglia. Stroke 1983;14:276-280.

6. Arboix A, Marti-Vilalta $J L$, Pujol J, Sanz M. Lacunar cerebral infarct and nuclear magnetic resonance. A review of sixty cases. Eur Neurol 1990;30:47-51.

7. Bamford J, Sandercock P, Jones $L$, Warlow $C$. The natural history of lacunar infarction: the Oxfordshire Community Stroke Project. Stroke 1987;18:545-551.

8. Bamford JM, Warlow CP. Evolution and testing of the lacunar hypothesis. Stroke 1988;19:1074-1082.

9. Bamford J, Sandercock $P$, Dennis M, Warlow $C$, Jones $L$, McPherson, Vessey $M$, Fowler G, Molyneux A, Hughes T, Burn J, Wade D. A prospective study of acute cerebrovascular disease in the community: the Oxfordshire Community Stroke Project 1981-86.1. Methodology, demography and incident cases of first-ever stroke. J Neurol Neurosurg Psychiatry 1988;51:1373-1380.

10. Bamford JM, Sandercock PAG, Warlow CP, Slattery J Interobserver agreement for the assessment of handicap in stroke patients (letter). Stroke 1989;20:828.

11. Bamford J, Sandercock P, Dennis M, Burn J, Warlow C. A prospective study of acute cerebrovascular disease in the community: the Oxfordshire Community Stroke Project-1981-86.2. Incidence, case fatality rates and overall outcome at one year of cerebral infarction, primary intracerebral and subarachnoid haemorrhage. J Neurol Neurosurg Psychiatry 1990;53:16-22.

12. Basso A, Della Salla S, Farabola M. Aphasia arising from purely deep lesions. Cortex $1987 ; 23: 29-44$.

13. Bendheim PE, Berg BO. Ataxic hemiparesis from a midbrain mass. Ann Neurol $1981 ; 9: 405-407$.

14. Bertrand $G$, Blundell J, Musella R. Electrical exploration of the internal capsule and neighbouring structures during stereotaxic procedures. J Neurosurgery $1965 ; 22 ; 333-343$. 
15. Biller J, Scardigli K. Ataxic hemiparesis from lesions of the corona radiata. Arch Neurol 1984;41:136-137.

16. Bladin PF, Berkovic SF. Striatocapsular infarction: large infarcts in the lenticulostriate arterial territory. Neurology 1984;34:1423-1430.

17. BMDP Statistical Software, Berkely: University of California Press: 1981.

18. Bogousslavsky J, Regli F, Ghika J, Feldmeyer JJ. Painful ataxic hemiparesis. Arch Neurol 1984; 41: 892-893.

19. Bogousslavsky J, Regli F. Unilateral watershed cerebral infarcts. Neurology 1986;36:373-377.

20. Bogousslavsky J, Miklossy J, Deruaz JP, Regli F. Thalamic aphasia. Neurology 1986;38:1662.

21. Bogousslavsky J, Fox AJ, Barnett HJM, Hachinski VC, Vinitski S, Carey LS. Clinico-topographic correlation of small vertebrobasilar infarct using magnetic resonance imaging. Stroke 1986;17:929-938.

22. Bogousslawsky J, Regli $F$, Uske A. Leukoencephalopathy in patients with ischemic stroke. Stroke 1987;18:896-899.

23. Bogousslawsky J, van Melle G, Regli F. The Lausanne Stroke Registry: analysis of 1000 consecutive patients with first stroke. Stroke 1988;19:1083-1092.

24. Bogousslavsky J, Van Melle G, Regli F. Middle cerebral artery pial territory infarcts: a study of the Lausanne Stroke Registry. Ann Neurol 1989;25:555-560.

25. Bonke B, Koudstaal PJ, Dijkstra G, Hilligersberg R van, Knippenberg FCE van, Duivenvoorden HJ, Kappelle LJ. Detection of lacunar infarction in brain CTscans: no evidence of bias from accompanying patient information.

Neuroradiology 1989;31:170-173.

26. Brodal A. Neurological anatomy in relation to clinical medicin. New York, Oxford University Press: 1981.

27. Brown JJ, Hesselink JR, Rothrock JF, MR and CT of lacunar infarcts. AJNR $1988 ; 9: 477-482$.

28. Bruggenhout $E$ van, Dehaene $\mathbb{I}$, Zandijcke $M$ van. Pontine ataxic hemiparesis. Arch Neurol 1984;41:16.

29. Brun $A$, Englund E. A white matter disorder in dementia of the Alzheimer type: a pathoanatomical study. Ann Neurol 1986;19:253-262.

30. Bruno A, Graff-Radford NR, Biller J, Adams Jr HP. Anterior choroidal artery territory infarction: a small vessel disease. Stroke 1989;20:616-619.

31. Bruyn RPM. Thalamic aphasia. A conceptional critique. J Neurol 1989;236:2125.

32. Caplan LR, Schoene WC. Clinical features of subcortical arteriosclerotic encephalopathy (Binswanger disease). Neurology 1978;28:1206-1215.

33. Caplan L, Babikian V, Helgason C, Hier DB, DeWitt D, Patel D, Stein R. Occlusive disease of the middle cerebral artery. Neurology 1985;35:975-982.

34. Caplan LR. Caroticl-artery disease. N Engl J Med 1986;315:886-888.

35. Caplan LR. Intracranial branch atheromatous disease: a neglected, understudied, and underused concept. Neurology 1989;39:1246-1250.

36. Caplan LR, Schmahmann JD, Kase CS, Feldmann E, Baquis G, Greenberg JP, 
Gorelick PB, Helgason C, Hier DB. Caudate infarcts. Arch Neurol 1990;47:133143.

37. Carpenter MB. Core text of neuroanatomy. Baltimore, Williams and Wilkins: 1985.

38. Chester EM, Agmanolis DP, Banker Q Victor M. Hypertensive encephalopathy. a clinicopathologic study of 20 cases. Neuroloy $1978 ; 28: 928-939$.

39. Chokroverty S, Rubino FA, Haller C. Pure motor hemiplegia due to pyramidal infarction. Arch Neurol 1975;32:647-648.

40. Chokroverty $S$, Rubino FA. "Pure' motor hemiplegia. J Neurol Neurosurg Psychiatry 1975;38:896-899.

41. Critchley M. The anterior cerebral artery, and its syndromes. Brain 1930;53:120 165.

42. Damasio AR, Damasio H, Rizzo M, Varney N, Gersh F. Aphasia with nonhemorrhagic lesions in the basal ganglia and internal capsule. Arch Neurol 1982;39:15-20.

43. Damasio H. A computed tomographic guide to the identification of cerebral vascular territories. Arch Neurol 1983;40:138-142.

44. Dechambre A. Mémoire sur la curabilité du ramoulissement cérébral. Gaz Med Paris 1838;6:305-314.

45. Delgado $\mathrm{G}$, Gallego J, Zubieta JL. High-resolution CT scan in pontine ataxic hemiparesis. J Neurol Neurosurg Psychiatry 1985;48:1069.

46. Demierre B, Rondot P. Dystonia caused by putamino-capsulo-caudate vascular lesions. J Neurol Neurosurg Psychlatry 1983;46:404-409.

47. DeRenzi E, Nichelli P, Crisi G. Hemiataxia and crural hemiparesis following capsular infarct. J Neurol Neurosurg Psychiatry 1983;46:561-563.

48. DeReuck $J \mathrm{~L}$, Schaumburg HH. Periventricular atherosclerotic leukoencephalopathy. Neurology 1972;22:1094-1097.

49. DeReuck JL, Eecken HM vander. Periventricular leukomalacia in adults. Arch Neurol 1978;35:517-521.

50. DeReuck J, Crevits $\mathrm{L}$, Coster W de, Sieben G, Eecken H van der. Pathogenesis of Binswanger chronic progressive subcortical encephalopathy. Neurology $1980 ; 30: 920-928$.

51. Derouesné $C$, Mas JL, Bolgert $F$, Castaigne P. Pure sensory stroke caused by a small cortical infarct in the middle cerebral artery territory. Stroke $1984 ; 15: 660$ 662 .

52. Donnan $\mathrm{GA}_{*}$ Tress BM, Bladin PF. A prospective study of lacunar infarction using computerized tomography. Neurology $1982 ; 32 ; 49-56$.

53. Donnan GA, Bladin PF. Capsular warning syndrome: repetitive hemiplegia preceding capsular stroke. Stroke 1987;18:296.

54. Englander $\mathrm{RN}$, Netsky $\mathrm{MG}$, Adelman LS. Location of human pyramidal tract in the internal capsule: anatomic evidence. Neurology 1975;25:823-826.

55. Faris AA, Poser CM. Wilmore DW, Agnew $\mathrm{CH}$. Radiologic visualization of neck vessels in healthy men. Neurology 1963;13:386-391.

56. Fazekas $F$, Niederkorn $K$, Schmidt R, Offenbacher H, Horner S, Bertha G, 
Lechner H. White matter abnormalities in normal individuals: correlation with carotid ultrasonography, cerebral blood flow measurements, and cerebrovascular risk factors. Stroke 1988;19:1285-1288.

57. Ferro $M$, Kertesz A. Posterior internal capsule infarction associated with neglect. Arch Neurol 1984;41:422-424.

58. Ferro JM, Kertesz A, Black SE. Subcortical neglect: quantitation ${ }_{r}$ anatomy $y_{r}$ and recovery. Neurology 1987;37:1487-1492.

59. Fisher CM. Lacunes: small, deep cerebral infarcts. Neurology 1965;15:774-784.

60. Fisher CM, Curry B. Pure motor hemiplegia of vascular arigin. Arch Neurol $1965 ; 13: 30-44$.

61. Fisher CM. Pure sensory stroke involving face, arm and leg. Neurology 1965; 15:76-80.

62. Fisher $\mathrm{CM}$, Cole $\mathrm{M}$. Homolateral ataxia and crural paresis: a vascular syndrome. 3 Neurol Neurosurg Psychiatry 1965;28:48-55.

63. Fisher CM.Alacunar stroke. The dysarthria-clumsy hand syndrome. Neurology 1967;17:614-617.

64. Fisher CM. The arterial lesions underlying lacunes. Acta Neuropathol (Berlin) 1969;12:1-15.

65. Fisher CM, Caplan LR. Basilar artery branch occlusion: a cause of pontine infarction. Neurology 1971;21:900-905.

66. Fisher CM. Bilateral occlusion of basilar artery branches. J Neurol Neurosurg Psychlatry 1977;40:1182-1189.

67. Fisher CM. Thalamic pure sensory stroke: a pathologic study. Neurology 1978;28:1141-1144.

68. Fisher CM. Ataxic hemiparesis. A pathologic study. Arch Neurol 1978;35:126128.

69. Fisher CM. Capsular infarcts. The underlying vascular lesions. Arch Neurol 1979;36:65-73.

70. Fisher CM. Lacunar strokes and infarcts: a review. Neurology 1982;32:871-876.

71. Fisher CM. Pure sensory stroke and allied conditions. Stroke 1982;13:434-447.

72. Fisher $M$, Recht LD. Brain tumor presenting as an acute pure motor hemiparesis. Stroke 1989;20:288-291.

73. Gandolfo $C_{r}$ Caponnetto C, Del Sette M, Santoloci D, Loeb C. Risk factors in lacunar syndromes: a case-control study. Acta Neurol Scand 1988;77:22-26.

74. Garcin $\mathbb{R}$. Syndrome cérébello-thalamique par lésion localisée du thalamus: avec une disgression sur le "signe de la main creuse" et son intérêt semiologique. Rev Neurol 1955;93:143-149.

75. Garcin R, Lapresele J. Incoordination cérébelleuse du membre inférieur par lésion localisée de la region interne du thalamus contralatéral. Rev Neurol 1969;120:5-13.

76. Gardner MJ, Altman DG. Confidence intervals rather than P values: estimation rather than hypothesis testing. Br Med J 1986;292:746-750.

77. Gardner MJ, Altman DG. Statistics with confidence - Confidence intervals and statistical guidelines. London, British Medical Journal: 1989.

78. Gaymard B, Autret A, Lamisse F, Larmande P. Chronic subdural hematoma 
presenting as ataxic hemiparesis. Eur Neurol 1989;29:77-79.

79. George AE, Leon MJ de, Gentes CI, Miller J, London E, Budzilowich GN, Ferris $S$, Chase N. Leukoencephalopathy in normal and pathologic aging: 1.CT of brain lucencies. AJNR 1986;7:561-566.

80. Ghika J, Bogousslavsky J, Regli F. Infarcts in the teritory of the deep perforators from the carotid system. Neurology 1989;39:507-512.

81. Gijn J van, Kraaijeveld CL. Blood pressure does not predict lacunar infarction. J Neurol Neurosurg Psychiatry 1982;45:147-150.

82. Gobernado JM, Fernandez de Molina AR, Gimeno A. Pure motor hemiplegia due to hemorrhage in the lower pons. Arch Neurol 1980;37:393.

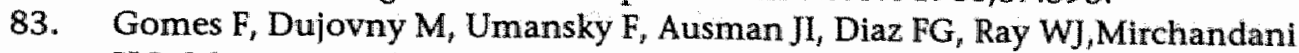
HG. Microsurgical anatomy of the recurrent artery of Heubner. I Neurosurg 1984;60:130-139.

84. Gomez CR, Gomez SM. Thalamic lesion producing ataxic hemiparesis (letter). Stroke 1988;19:1181.

85. Gorsselink EL, Peeters HPM, Lodder J. Causes of small deep infarcts detected by CT. Clin Neurol Neurosurg 1984;86:271-273.

86. Gorsselink EL, Lodder J. Pure sensory stroke with lacunar infarction in the posterior ventral thalamus on CT. Clin Neurol Neurosurg 1985;87:45-46.

87. Goto $\mathrm{K}$, Ischii $\mathrm{N}$, Fukasawa $\mathrm{H}$. Diffuse white-matter disease in the gerlatric population. A clinical, neuropatological, and CT study. Radiology 1981;141:687695.

88. Groothuis DR, Duncan GW, Fisher CM. The human thalamocortical sensory path in the internal capsule. Evidence from a small capsular hemorrhage causing a pure sensory stroke. Ann Neurol 1977;2:328-332.

89. Gross CR, Kase CS, Mohr JP, Cunningham SC, Baker WE. Stroke in South Alabama: incidence and diagnostic features - A population based study. Stroke 1984;15:249-255.

90. Gutmann DH, Scherer S. Magnetic resonance imaging of ataxic hemiparesis localized to the corona radiata. Stroke 1989;20:1571-1573.

91. Hachinski VC, Potter P, Merskey H. Leuko-Araiosis. Arch Neurol 1987;44:2123.

92. Han JS, Bonstelle CT, Kaufman B, Benson JE, Alfidi RJ, Clampitt M, Dyke C van, Huss RG. Magnetic resonance imaging in the evaluation of the brainstem. Radiology 1984;150:705-712.

93. Hanaway J, Young RR. Localization of the pyramidal tract in the internal capsule of man. J Neurol Sci 1977;34:63-70.

94. Harrison MJG, Marshall J. Angiographic appearance of carotid bifurcation in patients with completed stroke, transient laschaemic attacks, and cerebral tumour. Br Med J 1976;1:205-207.

95. Hatano S. Experience from a multicentre stroke register: a preliminary report. Bull WHO1976;54:541-553.

96. Healton EB, Navarro C, Bressman S, Brust JCM. Subcortical neglect. Neurology 1982;32:776-778.

97. Helgason C, Caplan LR, Goodwin J, Hedges III T. Anterior choroidal artery- 
territory infarction. Report of cases and review. Arch Neurol 1986;43:681-686.

98. Helgason CM. A new view of anterior choroidal artery territory infarction. J Neurol 1988;235:387-391.

99. Helgason CM, Wilbur AC. Capsular hypesthetic ataxic hemiparesis. Stroke $1990 ; 21: 24-33$.

100. Helweg-Larsen S, Larsson H, Henriksen O, Sorensen PS. Ataxic hemiparesis: three different locations of lesions studied by MRI. Neurology 1988;38:13221324.

101. Hennerici M, Aullich A, Sandmann W, Freund HJ. Incidence of asymptomatic extracranial arterial disease. Stroke 1981;12:750-758.

102. Herman B, Leyten ACM, Luyk JH van, Frenken CWGM, Op de Coul AAW, Schulte BPM. Epidemiology of stroke in Tilburg, The Netherlands. The population-based stroke incidence register: 2 . Incidence, initial clinical picture and medical care, and three-week case fatality. Stroke 1982;13:629-634.

103. Hirayama $K$, Tsubaki $T$, Toyokura $Y$, Okinaka $S$. The representation of the pyramidal tract in the internal capsule and basis pedunculi. A study based on three cases of amyotrophic lateral sclerosis. Neurology 1962;12:337-342.

104. Hijdra A, Verbeeten B, Verhulst JAPM. Relation of leuko-araiosis to lesion type in stroke patients. Stroke 1990;21:890-894.

105. Ho KL: Pure motor hemiplegia due to infarction of the cerebral peduncle. Arch Neurol 1982;39:524-526.

106. Hommel M, Besson G, Pollak P, Borgel F, Le Bas F, Perret J. Pure sensory stroke due to a pontine lacune. Stroke 1989;20:406-408.

107. Howard G, Toole JF, Becker C, Lefkowitz DF, Truscott L, Rose L, Evans GW. Changes in survival following stroke in five North Carolina counties observed during two different periods. Stroke 1989;20:345-350.

108. Huang CY, Lui FS. Ataxic-hemiparesis, localization and clinical features. Stroke 1984;14:363-366.

109. Huang C, Broe G. Isolated facial palsy: a new lacunar syndrome. J Neurol Neurosurg Psychiatry 1984;47:84-86.

110. Huang CY, Woo E, Yu YL, Chan FL. When is sensorimotor stroke a lacunar syndrome? J Neurol Neurosurg Psychiatry 1987;50:720-726.

111. Hurwitz BJ, Heyman A, Drayer B, Utley C. Cerebral white matter hypodensity in computed tomographical brain scans: an indication of Binswanger's disease? Ann Neurol 1984;16:155-156.

112. Ichikawa K, Tsutsumishita A, Fujioka A. Capsular ataxic hemiparesis. A case report. Arch Neurol 1982;39:585-586.

113. Inzitari D, Diaz F, Fox A, Hachinski VC, Steingart A, Lau C, Donald A, Wade J, Mulic $\mathrm{H}$, Merskey $\mathrm{H}$. Vascular risk factors and leuko-araiosis. Arch Neurol 1987;44:42-47.

114. Iragui VJ, McCutchen CB. Capsular ataxic hemiparesis. Arch Neurol 1982;39:528529.

115. Ishii $\mathrm{N}$, Nishihara $\mathrm{Y}$, Imamura $\mathrm{T}$. Why do frontal lobe symptoms predominate in vascular dementia with lacunes? Neurology 1986;36:340-345.

116. Jacome D. Homolateral ataxia and crural paresis. Arch Neurol 1983;40:659- 
660.

117. Jokelainen M, Pilke A. Ataxic hemiparesis. Arch Neurol 1983,40:326.

118. Kappelle LJ, GijnJ van. Lacunar infarcts. Clin Neurol Neurosurg 1986,88:3-17.

119. Kappelle LJ, Koudstaal PJ, Gijn J van, Ramos LMP, Keunen JEE. Carotid angiography in patients with lacunar infarction. Stroke 1988;19:1093-1096.

120. Kappelle LJ, Ramos LMP, Gijn J van. The role of computed tomography in patients with lacunar stroke in the carotid territory. Neuroradiology $1989,31: 316$. 319.

121. Kappelle LJ. The lacunar infarct. A separate stroke entity. Thesis. University of Utrecht, 1990.

122. Kase CS, Maulsby GO, DeJuan E, Mohr JP. Hemichorea-hemiballism and lacunar infarction in the basal ganglia. Neurology 1981;31:452-455.

123. Kinkel WR, Jacobs L, Polachinil I, Bates V. Late-onset subcortical encephalopathy: computed tomographic, nuclear magnetic resonance, and clinical correlations. Ann Neurol 1984;16:137-138.

124. Kinkel WR, Jacobs L, Polachini 1 , Bates V, Heffner RR. Subcortical arteriosclerotic encephalopathy (Binswanger's disease). Computed tomographic, nuclear magnetic resonance, and clinical correlations. Arch Neurol 1985;42;951-959.

125. Kistler JP, Buonanno FS, DeWitt LD, Davis KR, Brady TJ, Fisher CM. Vertebralbasilar posterior cerebral territory stroke-Delineation by proton nuclear magnetic resonance imaging. Stroke 1984;15:417-426.

126. Kobatake K, Shinohara $Y$. Ataxic hemiparesis in patients with primary pontine hemorrhage. Stroke 1983;14:762-764.

127. Koppel BS, Weinberger G. Pontine infarction producing dysarthria-clumsy hand syndrome and ataxic hemiparesis. Eur Neurol 1987;26:211-215.

128. Kretschmann HJ, Weintich W. Neuroanatomy and cranial computed tomography. New York, George Thieme Verlag Stuttgart: 1986.

129. Kunitz SC, Gross CR, Heyman A, Kase CS, MohrJP, Price TR, Wolf PA. The pilot stroke data bank: definition, design and data. Stroke 1984;15:740-746.

130. Lahat E, Lanzieri C, Wallace SA, Aron AM. Pedatric brain stem tumor presenting as a pure motor hemiparesis. Clin Neurol Neurosurg 1989;91:61-63.

131. Landi $G$, Anzalone $N$, Vaccari $U$. CT scan evidence of postero-lateral thalamic infarction in pure sensory stroke. J Neurol Neurosurg Psychiatry 1984;47:570571.

132. Lee $N$, Roh $J K$, Myung $H$. Hypesthetic ataxic hemiparesis in a thalamic lacune. Stroke $1989 ; 20: 819-821$.

133. Leestma JE, Noronha A. Pure motor hemiplegia, medullary pyramid lesion, and olivary hypertrophy. J Neurol NeurosurgPsychiatry 1976;39:877-884.

134. Levine $\mathrm{RL}$, Lagreze HL, Dobkin JA, Turski PA. Large subcortical hemispheric infarctions. Presentation and prognosis. Arch Neurol 1988;45:1074-1077.

135. Levitt LP, Selkoe DJ, Frankenfield B, Schoene W. Pure motor hemiplegia secondary to brain-stem tumour. J Neurol Neurosurg Psychlatry 1975;38:12401243 .

136. LodderJ, Baard WC. Paraballism caused by bilateral hemorthagic infarction in basal ganglia. Neurology 1981;31:484-486. 
137. Lodder J, Bamford JM, Sandercock $P A G_{f}$ Jones LN, Warlow CP. Are hypertension or cardiac embolism likely causes of lacunar infarction? Stroke 1990;21:375381.

138. Loeb C, Gandolfo $C_{n}$ Mancardi GL, Primavera A, Tassinari T. The lacunar syndromes: a review with personal contribution. In: Cerebrovascular disease: Research and Clinical Management Vol 1. Lechner H, Meyer JS, Ott E, Eds. Amsterdam, Elsevier: 1986:107-156.

139. Loizou LA, Kendall BE, Marshall J. Subcortical arteriosclerotic encephalopathy: a clinical and radiological investigation. J Neurol Neurosurg Psychiatry 1981;44:294-304.

140. Loizou LA, Jefferson JM, Thomas Smith W. Subcortical arteriosclerotic encephalopathy (Binswanger's type) and cortical infarcts in a young normotensive patient. J Neurol Neurosurg Psychiatry 1982;45:409-417.

141. Manelfe C, Clanet $M$, Gícaud $M$, Bonafé $A$, Guiraud B, Rascol A. Internal capsule: normal anatomy and ischemic changes demonstrated by computed tomography. AJNR 1981;2:149-155.

142. Marie $\mathbb{P}$. Des foyers lacunaires de désintégration et de différents autres états cavitaires du cerveau. Rev Méd (Paris) 1901;21:281-298.

143. MarinkovicSV, Milisavljevic MM, Kovacevic MS, StevicZD. Perforating branches of the middle cerebral artery. Microanatomy and clinical significance of their intracerebral segments. Stroke 1985;16:1022-1029.

144. Marinkovic SV, Milisavljevic MM, Kovacevic MS. Anastomoses among the thalamoperforating banches of the posterior cerebral artery. Arch Neurol $1986 ; 43: 811-814$

145. McQuinn BA, O'Leary DH. White matter lucencies on computed tomography, subacute arteriosclerotic encephalopathy (Binswanger's disease), and blood pressure. Stroke 1987;18:900-905.

146. Medical Research Council. Aids to the examination of the peripheral nervous system. London, Her majesty's stationary office: 1982.

147. Merwijk $G$ van, Lodder J, Bamford J, Kester ADM. How often is nonvalvular atrial fibrillation the cause of brain infarction ? J Neurol 1990;237:205-207.

148. Miller VT. Lacunar stroke. A reassessment. Arch Neurol 1983;40:129-134.

149. Moffie D, Ongerboer de Visser BW, Sande JJ van der. "Pure motor hemiplegia". De plaatsbepaling van de pyramidebaan in de capsula interna. Ned T Geneesk $1979 ; 123: 822-825$.

150. Mohr JP, Kase CS, Meckler RJ, Fisher CM. Sensorimotor stroke due to thalamocapsular ischemia. Arch Neurol 1977;34:739-741.

151. Mohr JP, Caplan LR, Melski JW, Goldstein RJ, Duncan GW, Kistler JP, Pessin MS, Bleich HL. The Harvard Cooperative Stroke Registry: a prospective registry. Neurology 1978;28:754-762.

152. Mohr JP. Lacunes. Stroke 1982;13:3-11.

153. Mohr JP. Lacunes. Neurol Clin N Am 1983;1:201-221.

154. Mohr JP. Lacunes. In: Stroke. Pathophysiology, diagnosis, and management. Barnett HJM, Stein BM, MohrJP, Yatsu FM, Eds. New York, Churchill Livingstone: 1986:475-496. 
155. Mori E, Yamadori A, Kudo $Y$, Tabuchi M. Ataxic hemiparesis from small capsular hemorrhage. Computed tomography and somatosensory evoked potentials. Arch Neurol 1984;41:1050-1053.

156. Mori $\mathrm{E}_{r}$ Tabuchi $\mathrm{M}$, Yamadori A. Lacunar syndrome due to intracerebral hemorrhage. Stroke 1985;16:454-459.

157. Morris JA, Gardner MJ. Calculating confidence intervals for relative risks (odds ratios) and standardised ratios and rates. Br Med J 1988;296:1313-1316.

158. Murthy JMK. Ataxic hemiparesis-Ventrolateral nucleus of the thalamus: yet another site of lesion (letter). Stroke 1988;19:122.

159. Nabatame H, Fukuyama $H$, Akiguchi I, Kameyama $M$, Nishimura $K$, Torizuka K. Pontine ataxic hemiparesis studied by a high-resolution magnetic resonance imaging system. Ann Neurol 1987;21:204-207.

160. Naeser MA, Alexander MP, Helm-Estabrooks N, Levine HL, Laughlin SA, Geschwind N. Aphasia with predominantly subcortical lesion sites. Description of three capsular/putaminal aphasia syndromes. Arch Neurol 1982;39:2-14.

161. Nelson RF, Pullicino P, Kendall BE, Marshall J. Computed tomography in patients presenting with lacunar syndromes. Stroke 1980;11:256-261.

162. Norris JW, Zhu CZ. Stroke risk and critical carotid stenosis. J Neurol Neurosurg Psychiatry 1990;53:235-237.

163. Norrving $B$, Cronqvist $S$. Clinical and radiologic features of lacunar versus nonlacunar minor stroke. Stroke 1989;20:59-64.

164. Olsen TS, Skriver EB, Herning M. Cause of cerebral infarction in the carotid territory. Its relation to the size and the location of the infarct and to the underlying vascular lesion. Stroke $1985 ; 16: 459-466$.

165. Olsen TS, Bruhn P, Oberg RGE. Cortical hypoperfusion as a possible cause of "subcortical aphasia". Brain 1986;109:393-410.

166. Pantano P, Baron JC, Samson Y, Bousser MG, Derouesne C, Comar D. Crossed cerebellar diaschisis. Brain 1986;109:677-694.

167. Perman GP, Racy A. Homolateral ataxia and crural paresis: case report. Neurology 1980;30:1013-1015.

168. Poirier J, Derouesne C. Le concept de lacune cérébrale de 1838 à nous jours. Rev Neurol (Paris) 1985;141:3-17.

169. Pullicino P, Nelson RF, Kendall BE, Marshall J. Small deep infarcts diagnosed on computed tomography. Neurology 1980;30:1090-1096.

170. Pullicino P, Eskin T, Ketonen L. Prevalence of Binswanget's disease. The Lancet 1983;23:939.

171. Rankin J. Cerebral vascular accidents in people over the age of 60. II. Prognosis. Scott Med J 1957;2:200-215.

172. Rascol A, Clanet M, Manelfe C, Guiraud B, Bonafe A. Pure motor hemiplegia: CT study of 30 cases.Stroke 1982;13:11-17.

173. Rezek DL, Morris JC, Fulling KH, Gado MH. Periventricular white matter lucencies in SDAT and healthy aging. Neurology 1986;36:263-264.

174. Ricci S, Celani MG, Guercini G, Rucireta P, Vitali R, La Rosa F, Duca E, Ferraguzzi R, Paolotti M, Seppoloni D, Caputo N, Chiurulla C, Scaronu R, Signorini E. Firstyear results of a community-based study of stroke incidence in Umbria, Italy. 
Stroke 1989;20:853-857.

175. Ringelstein $\mathrm{EB}$; Zeumer $\mathrm{H}$, Angelou $\mathrm{D}$. The pathogenesis of strokes from internal carotid artery occlusion. Diagnostic and therapeutical implications. Stroke $1983 ; 14: 867-875$.

176. Robinson RK, Richey ET, Kase CS, Mohr JP. Somatosensory evoked potentials in pure sensory stroke and related conditions. Stroke 1985;16:818-823.

177. Ropper $\mathrm{AH}_{i}$ Fisher $\mathrm{CM}$, Kleinman GM. Pyramidal infarction in the medulla: a cause of pure motor hemiplegla sparing the face. Neurology $1979 ; 29: 91-95$.

178. Rosenberg GA, Kornfeld M, Stovring J, Bicknell JM. Subcortical arteriosclerotic encephalopathy (Binswanger): computerized tomography. Neurology 1979;29:1102-1106.

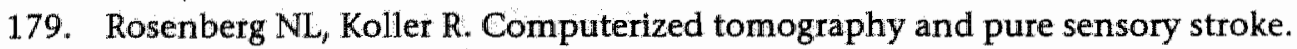
Neurology 1981;31:217-220.

180. Rosner SS, Rhoton AL, Ono M, Barry M. Microsurgical anatomy of the anterior perforating arteries. J Neurosurg 1984;61:468-485.

181. Ross ED. Localization of the pyramidal tract in the internal capsule by whole brain dissection. Neurology 1980;30:59-64.

182. Rothrock JF, Lyden PD, Hesselink JR, Brown JJ, Healy ME. Brain magnetic resonance imaging in the evaluation of lacunar stroke. Stroke $1987 ; 18: 781$ 786.

183. Roy EP, Keefover RW, RiggsJE, Marano GD. Dysarthria-clumsy hand syndrome and cerebellar hemorrhage. Ann Neurol 1987;21:415-416.

184. Russo LS. Focal dystonia and lacunar infarction of the basal ganglia. A case report. Arch Neurol 1983;40:61-62.

185. Sacco RL, Bello JA, Traub $\mathrm{R}$, Brust JCM. Selective proprioceptive loss from a thalamic lacunar stroke. Stroke 1987;18:1160-1163.

186. Sackett DL, Haynes RB, Tugwell P. Clinical epidemiology. A basic science for clinical medicine. Boston, Little, Brown and Company: 1985

187. Sage JI, Lepore FE. Ataxic hemiparesis from lesions of the corona radiata. Arch Neurol 1983;40:449-450.

188. Sandercock P. The odds ratio: a useful tool in neurosciences. J Neurol Neurosurg Psychiatry $1989 ; 52: 817-820$.

189. Santamaria J, Graus F, Rubio F, Arbizu T, Peres J. Cerebral infarction of the basal ganglia due to embolism from the heart. Stroke 1983;14:911-914.

190. Scheinberg P. Controversies in the management of cerebral vascular disease. Neurology 1988;38:1609-1616.

191. Schnapper RA. Pontine hemorrhage presenting as ataxic hemiparesis. Stroke 1982;13:518-519.

192. Schulte BPM, Leyten ACM, Herman B. Differing aspects of pre-stroke and poststroke hypertension. In: Central nervous system control of the heart. Stober T, Schimrigh K, Ganten D, Sherman DG, Eds. Boston, Martinus Nijhoff:1986:145152.

193. Sipponen JT. Visualization of brain infarction with nuclear magnetic resonance imaging. Neuroradiology 1984;26:387-391. 
194. Spence JD, Donner A. Problems in design of stroke treatment trials. Stroke 1982;13:94-99.

195. Spertell RB, Ransom BR. Dysarthria-clumsy hand syndrome produced by capsular infarct. Ann Neurol 1979;6:263-265.

196. Stein $\mathrm{S}$, Volpe BT. Classical "parietal" neglect syndrome after subcortical right frontal lobe infarction. Neurology 1983;33:797-799.

197. Steingart A, Hachinski VC, Lau C, Fox AJ, Diaz F, Cape R, Lee D, Inzitari D, Merskey $\mathrm{H}$. Cognitive and neurologic findings in subjects with diffuse white matter lucencies on computed tomographic scan (leuko-aralosis). Arch Neurol 1987;44:32-35.

198. Steingart A, Hachinski VC, Lau C, Fox AJ, Fox H, Lee D, Inzitari D, Merskey H. Cognitive and neurologic findings in demented patients with diffuse white matter lucencies on computed tomographic scan (leuko-araiosis). Arch Neurol 1987;44:36-39.

199. Stiller J, Shanzer S, Yang W. Brainstem lesions with pure motor hemiparesis. Computed tomographic demonstration. Arch Neurol 1982;39:660-661.

200. Swieten JC van, Koudstaal PJ, Visser MC, Schouten HJA, Gijn J van. Interobserver agreement for the assessment of handicap in stroke patients. Stroke 1988;19:604607.

201. Takahashi $\mathrm{S}_{i}$ Goto K, Fukasawa H, Kawata $\mathrm{Y}$, Uemura K, Suzuki K. Computed tomography of cerebral infarction along the distribution of the basal perforating arteries. Part 1: Striate arterial group. Radiology 1985;155:107-118.

202. Takahashi S, Goto K, Fukasawa H, Kawata Y, Uemura K, Yaguchi K. Computed tomography of cerebral infarction along the distribution of the basal perforating arteries. Part 2: Thalamic arterial group. Radiology 1985;155:119-130.

203. Tanridag $\mathrm{O}$, Kirshner HS. Aphasia and agraphia in lesions of the posterior internal capsule and putamen. Neurology 1985;35:1797-1801.

204. Tapia JF, Kase CS, Sawyer RH, Mohr JP. Hypertensive putaminal hemorrhage presenting as pure motor hemiparesis. Stroke 1983;14: 505-506.

205. Tegeler CH, Shi F, Hart RG, Sherman DG, Morgan T. Carotid stenosis in lacunar stroke. Stroke $1989 ; 20: 141$.

206. The Dutch TIA Study Group. The Dutch TIA trial: protective effects of low-dose aspirin and atenolol in patients with transient ischemic attacks or nondisabling stroke. Stroke 1988; 19:512-517.

207. Tredici G, Bogliun G, Sanguineti I. Capsular ataxic hemiparesis. Arch Neurol 1983;40:326.

208. Tuhrim S, Yang WC, Rubinowitz H, Weinberger J. Primary pontine hemorrhage and the dysarthria-clumsy hand syndrome. Neurology 1982;32:1027-1028.

209. Tuszynski MH, Petito CK. Ischemic thalamic aphasia with pathologic confirmation. Neurology 1988;38:800-802.

210. Tuttle PV, Reinmuth OM. Midbrain hemorrhage producing pure sensory stroke. Arch Neurol 1984;41:794-795.

211. UK-TIA Study Group. The UK-TIA aspirin trial: interim results. Br Med J 1988;296:216-220.

212. Valentine AR, Mosely IF, Kendall BE. White matter abnormality in cerebral 
atrophy: cliniscoradiological correlations. J Neurol Neurosurg Psychiatry 1980;43:139-142.

213. Verma AK, Maheshwari MC. Hypesthetic ataxic hemiparesis in thalamic hemorrhage. Stroke 1986; 17: 49-51.

214. Vries L de, Sno HN. Atactische hemiparese en "dysarthria-clumsy hand", twee verwante syndromen veroorzaakt door een lacunair herseninfarct. Ned Tijdschr Geneeskd 1985;129:1628-1631.

215. Weiller $C$, Ringelstein EB, Reiche $W$; Thron $A$, Buell $U$. The large striatocapsular infarct. A clinical and pathophysiological entity. Arch Neurol 1990;47:10851091.

216. Weisberg LA. Computed tomography and pure motor hemiparesis. Neurology $1979 ; 29: 490-495$.

217. Weisberg LA. Lacunar infarcts. Clinical and computed tomographic correlations. Arch Neurol 1982;39:37-40.

218. Weisberg LA, Wall M. Small capsular hemorrhages. Clinical-computed tomographic correlations. Arch Neurol 1984;41:1255-1257.

219. Weisberg LA. Diagnostic classification of stroke, especially lacunes. Stroke 1988; 19:1071-1073.

220. Wolf PA, Kannel WB, McGee DL. Prevention of ischemic stroke: risk factors. In: Stroke. Pathofysiology, diagnosis, and management. Barnett HJM, Stein BM, Mohr JP, Yatsu FM, Eds. New York, Churchill Livingstone: 1986.

221. Zeumer Von $\mathrm{H}$, Ringelstein EB, Klose KC. Lakunare infarkte in computertomogramm. Angiographische befunde und differentialdiagnostische gesichtspunkte. Fortschr Röntgenstr 1981;134:488-494. 


\section{List of publications}

Boiten J, Hageman G, Graaff R de. The conservative treatment of patients presenting with Grisel's syndrome. Clin Neurol Neurosurg 1986;88:95-99.

Boiten I, Hageman G, Graaff $R$ de. De conservatieve behandeling van patienten met het syndroom van Grisel. Ned Tijdschr Geneeskd 1987;131:37 (Abstract).

Boiten J, Jansen ENH, Graaff R de. Von Recklinghausen neurofibromatosis (VRNF) and pregnancy. A single case study. Clin Neurol Neurosurg 1987;89:181-184.

Boiten J. Epidural haematoma of the posterior fossa: good results after prompt diagnosis with CT. J Neurol Neurosurg Psychiatry 1989;52:915-916.

Boiten J, Lodder J. Een zeldzaam gevolg van een vaak voorkomende neurologische aandoening: delier door herseninfarct. Ned Tijdschr Geneeskd 1989;133:617-620.

Boiten J, Lodder J. A rare consequence of a frequent neurological disorder: delirium after cerebral infarction. Clin Neurol Neurosurg 1989;91:185 (Abstract).

Boiten J, Lodder J. Delirium following right middle cerebral artery infarction. Neurology India 1989;37 (suppl.):24 (Abstract).

Boiten J, Lodder J. Ataxic hemiparesis following thalamic infarction. Stroke 1990;21:339-340.

Boiten J, Lodder J. Cardiac and carotid embolism are unlikely causes of lacunar infarction. J Neurol 1990;237:150 (Abstract).

Lodder J, Boiten J. Leuko-araiosis on CT in patients with lacunar infarction. J Neurol 1990;237:150 (Abstract).

Boiten J, Lodder J, Lugt PJM van der. Cerebrale doorbloedingsstoornissen. The Practioner 1990;7:1120-1124.

Boiten J, Lodder J. Two distinct clinical lacunar stroke entities. Proceedings of the International Conference on Stroke 1991. In press (Abstract). 
Boiten J, Lodder J. Isolated monoparesis is usually caused by superficial infarction. Cerebrovasc Dis 1991. In press.

Boiten J, Lodder J. Delirium following right middle cerebral infarction. Submitted.

Boiten J, Lodder J. Lacunar infarcts; pathogenesis and validity of the clinical syndromes. Submitted.

Boiten J, Lodder J. Natural history and type of recurrent infarction in lacunar stroke. Submitted.

Boiten J, Lodder J. Leuko-arailosis and lacunar infarcts usually result from small vessel disease. Submitted.

Boiten J, Lodder J. Two clinically distinct lacunar stroke entities. Submitted.

Boiten J, Lodder J. Large subcortical infarcts: clinical presentation and pathogenesis in comparison with lacunar and cortical infarcts. Submitted.

Boiten J, Lodder J. The course of corticospinal, thalamocortical, and cerebellar pathways in man inferred from lacunar infarct patients. Submitted. 


\section{Acknowledgements}

I want to thank the following persons who have contributed to this study:

I am particularly grateful to my co-promotor Dr. Jan Lodder, who introduced me to clinical research and interested me in "LACI'S".

Prof. Rob Reneman for his helpful comments and for his support during the final stage of this study.

Prof. Paul van der Lugt for his interest and support during this study.

The members of the "Beoordelingscommissie", Dr. Jaap Kappelle and Dr. John Bamford for their helpful comments.

André Terlingen for lay-out of this thesis.

Hans Evers for a final check of the English.

Furthermore, I want to thank Dr. Slobodan Marinkovic for kind permission of using his photograph for the cover design, Lisette Heuts-van Raak for her aid in completing the follow-up, Ger Lassouw for his aid in constructing the Kaplan-Meier curves, and Reinhardt Boiten for drawing Figure 8.1.

Inge, your effort, support, interest and enthusiasm have been essential in the completion of this thesis. 


\section{Curriculum vitae}

The author was born on November 8, 1957 in Hollandia, Netherlands New Guinea. He completed secondary school ('V.W.O') in 1976. After studying chemistry during one year, he started medical training at the University of Utrecht in 1977. During medical study, he worked at the Department of Anatomy (Prof. Dr. N. Gluhbegovic), and he was involved in research at the Department of Neurosurgery (Head Prof. Dr. C.A.F. Tulleken). After completing medical training in February 1984, he did his military service as a Medical Officer in the Royal Netherlands Navy. During this period, he worked as a ship's surgeon on HNLMS Abraham Crijnssen for 15 months. A course in diving medicine was done at the Diving Medical Center of the Royal Netherlands Navy. Neurological training was started in September 1985 at the Department of Neurology of Ziekenzorg Hospital in Enschede (Head Dr. J. Troost). After a one year residency in Neurosurgery -from 1986 to 1987- at the Department of Neurosurgery of the University Hospital Dijkzigt in Rotterdam (Heads Prof. Dr. C.J.J. Avezaat and Prof. Dr. R. Braakman), he continued neurological training in November 1987 at the Department of Neurology of the University Hospital Maastricht (Head Prof. Dr. P.J.M. van der Lugt). At this department, he is involved in cerebrovascular research in collaboration with Dr. J. Lodder. Training in Clinical Neurophysiology was started in September 1990 at the same hospital (Head Prof. Dr. F. Spaans). 